\title{
Análise do metabolismo de polifosfato e do operon pst em Pseudomonas aeruginosa
}

Dissertação apresentada ao Programa de PósGraduação em Microbiologia do Instituto de Ciências Biomédicas da Universidade de São Paulo, para obtenção do Título de Mestre em Ciências. 


\section{Análise do metabolismo de polifosfato e do operon pst em Pseudomonas aeruginosa}

Dissertação apresentada ao Programa de PósGraduação em Microbiologia do Instituto de Ciências Biomédicas da Universidade de São Paulo, para obtenção do Título de Mestre em Ciências.

Área de concentração: Microbiologia

Orientador: Prof. Dr. Beny Spira

Versão original

São Paulo

2015 
DADOS DE CATALOGAÇÃO NA PUBLICAÇÃO (CIP)

Serviço de Biblioteca e Informação Biomédica do

Instituto de Ciências Biomédicas da Universidade de São Paulo

reprodução não autorizada pelo autor

Munévar, Nicolás Federico Villamil.

Análise do metabolismo de polifosfato e do operon pst em Pseudomonas aeruginosa / Nicolás Federico Villamil Munévar. -- São Paulo, 2015.

Orientador: Prof. Dr. Beny Spira.

Dissertação (Mestrado) - Universidade de São Paulo. Instituto de Ciências Biomédicas. Departamento de Microbiologia. Área de concentração: Microbiologia. Linha de pesquisa: Genética e adaptação de bactérias ao ambiente com ênfase na captação de fontes de fósforo; mutações adaptativas; evolução dirigida e biorremediação de àguas residuárias.

Versão do título para o inglês: Analysis of the metabolism of polyphosphate and the pst operon in Pseudomonas aeruginosa.

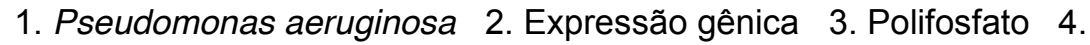
Fosfato 5. Operon pst 6. phoU I. Spira, Prof. Dr. Beny II. Universidade de São Paulo. Instituto de Ciências Biomédicas. Programa de Pós-Graduação em Microbiologia III. Título. 
Candidato(a):

Título da Dissertação:

Orientador(a):
Nicolás Federico Villamil Munévar.

Análise do metabolismo de polifosfato e do operon pst em Pseudomonas aeruginosa.

A Comissão Julgadora dos trabalhos de Defesa da Dissertação de Mestrado, em sessão pública realizada a ..................., considerou

( ) Aprovado(a)

( ) Reprovado(a)

Examinador(a): Assinatura:

Nome:

Instituição:

Examinador(a): Assinatura:

Nome:

Instituição:

Presidente:

Assinatura:

Nome:

Instituição: 


\section{CERTIFICADO DE ISENÇÃO}

Certificamos que o Protocolo CEP-ICB N $\mathrm{N}^{\circ}$ 556/12 referente ao projeto intitulado: "O metabolismo de polifosfato em $P$. aeruginosa $e$ a sua relação com o operon pst e o gene pit” sob a responsabilidade de Nicolás Federico Villamil Munévar, foi analisado na presente data pela CEUA - COMISSÃO DE ÉTICA NO USO DE ANIMAIS e pela CEPSH- COMISSÃO DE ÉTICA EM PESQUISA COM SERES HUMANOS, tendo sido deliberado que o referido projeto não utilizará animais que estejam sob a égide da lei 11.794 de 8 de outubro de 2008, nem envolverá procedimentos regulados pela Resolução CONEP nº196 de 1996.

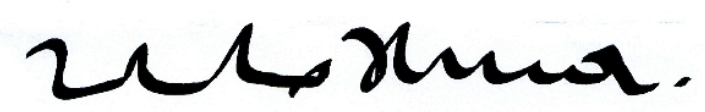

PROF. DR. Wothan TAVARES DE LIMA Coordenador da CEUA - ICB/USP
São Paule, $1 Q$ de outubro de 2012.

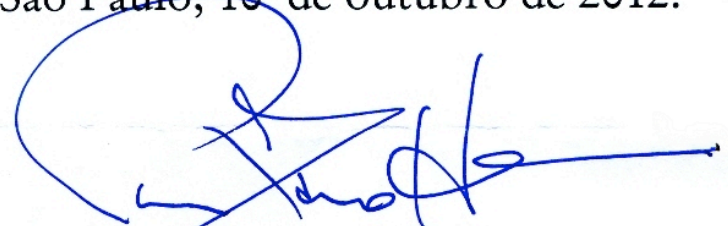

PROF. DR. PAOLO M.A ZANOTTO Coordenador da CEPsh - ICB/USP 


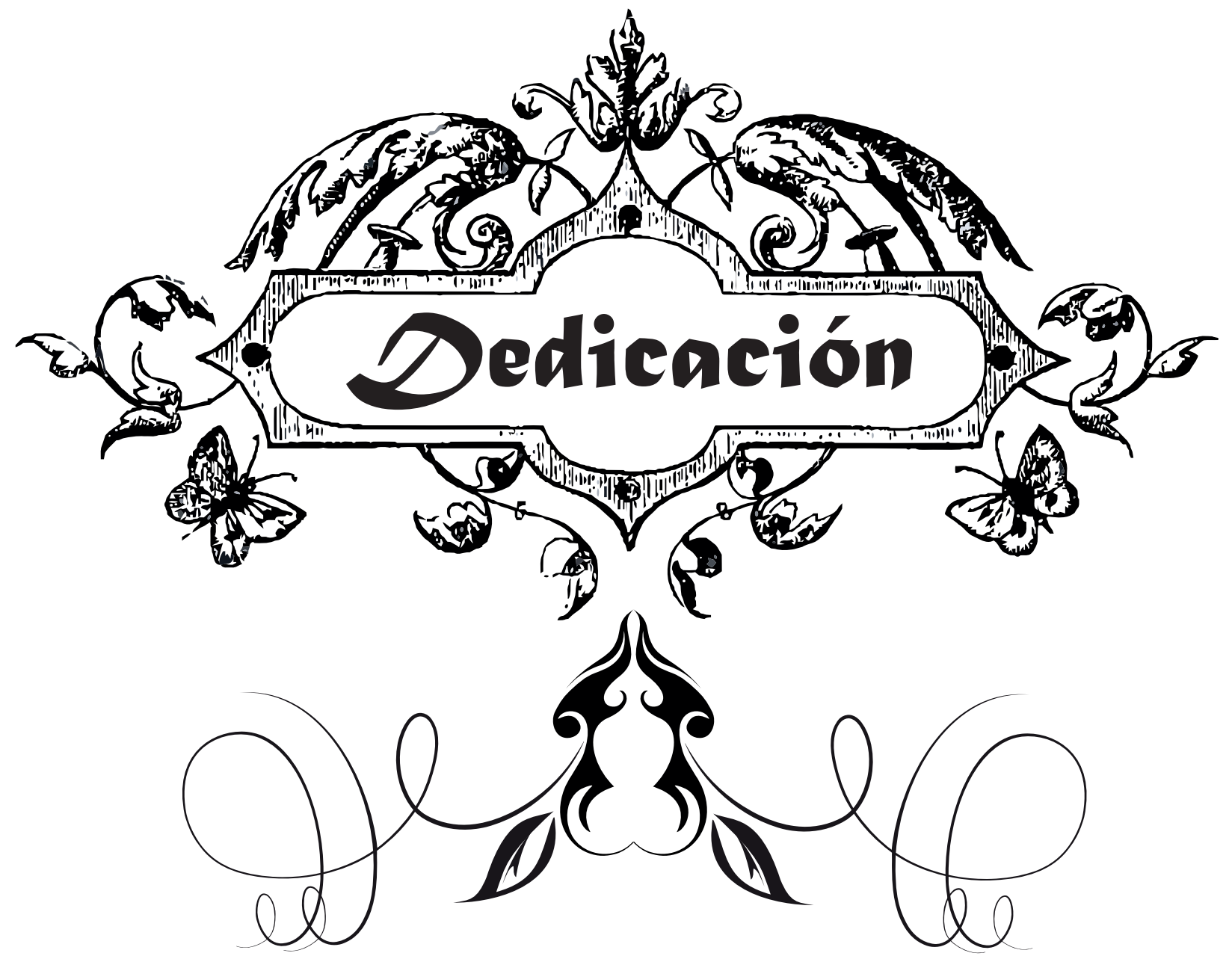

ESTE TRABAJo ESTÁ DEDICAdo A Mi FAMILIA Y AMIGos, PERo, MUY ESPECIALMENTE, A MIS PADRES, PABLO Y SUSANA, CUYO INMENSO CARIÑO, COMPAÑ́íA Y APOYO EN CADA UNO DE LOS PROYECTOS EMPRENDIDOS DESDE NIÑO ME PERMITIERON

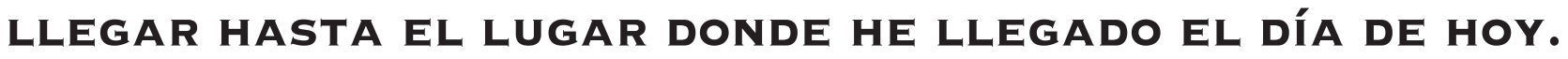




\section{AGRADECIMENTOS}

Ao prof. Dr. Beny Spira, quem representou meu primeiro contato com o Brasil. Agradeço por abrir-me as portas de seu laboratório. Agradeço pelo apoio constante durante todo o mestrado, pela confiança depositada em mim e em meu trabalho, pelos ensinamentos da área, teóricos e experimentais, e pela extrema paciência. Agradeço também o imensurável apoio na escrita de minha dissertação. Por favor, saiba que tem toda minha admiração e gratidão. Sua dedicação pelo trabalho de seus alunos é realmente admirável.

Em especial, à Fundação de Amparo à Pesquisa do Estado de São Paulo (FAPESP) e à Coordenação de Aperfeiçoamento de Pessoal de Nível Superior (CAPES), pelo apoio financeiro.

À Universidade de São Paulo e ao Departamento de Microbiologia, pela oportunidade de fazer parte de seu corpo discente.

Ao Luiz, meu primeiro companheiro de mestrado. Agradeço por ter sido receptivo sempre que precisei de ajuda em meus experimentos, por seus ensinos em técnicas e metodologias empregadas em minha pesquisa, por seus aportes em meu trabalho, e pela imensa ajuda na formatação deste documento. Por fim, agradeço também pela amizade.

À Gard, por ter-me acolhido em sua família e em seu coração. Você sabe que minha vida mudou assim que você chegou ao laboratório. Agradeço também pela ajuda em meus experimentos, e pelas sugestões e correções em meus documentos e em minha pesquisa em geral. Agradeço, também, por seu carinho e pela grande amizade.

Aos meus companheiros e amigos do laboratório 114: à Talita, por tirar de mim sempre um sorriso e por ter sido sempre atenciosa com minhas dúvidas de português; ao Rulho, por ser um exemplo de esforço, dedicação e de amor pela ciência; à Tuanny, por ser uma grande amiga, sempre disposta a me escutar quando precisei me desabafar, e por ter sido minha professora oficial de português ao longo do mestrado; à Jacke e à Auri, pelas conversas e bons momentos; e à Lívia, Jung, Luiza, Natália e ao Alessandro, pela companhia e momentos de descontração no laboratório.

Ao Emílio e à Larissa, pelo inestimável apoio com todas as questões técnicas do laboratório. Sem dúvida, vocês fizeram minha pesquisa muito mais simples. Agradeço também pelas conversas e pela amizade.

À profa. Dra. Cristiane Guzzo, por ter-me fornecido gentilmente o vetor pET-28a $(+)$ e pelas orientações nos experimentos de clonagem, expressão e purificação de PhoB. Agradeço ao prof. Dr. Robson de Souza e, novamente, à profa. Dra Cristiane Guzzo, por terem-me permitido utilizar os equipamentos de seu laboratório quando precisei purificar a proteína PhoB. Agradeço também a suas estudantes Fernanda e Cecília, pela ajuda com a utilização dos equipamentos e por ter compartilhado comigo suas experiências na área.

À profa. Dra. Regina Baldini, por ter-me fornecido gentilmente o vetor Mini-CTXlacZ e por suas sugestões oportunas em meu trabalho. Agradeço também aos seus orientados: Ana Laura, Gianlucca, Ana Paula e Gilberto, por ampliarem meus conhecimentos 
por meio de discussões acadêmicas, as quais foram de grande ajuda em minha pesquisa.

À profa. Dra. Marílis Marques, por ter-me proporcionado a possibilidade de fazer parte de uma das turmas de sua maravilhosa disciplina Fundamentos de Biologia Molecular Bacteriana, e por ter-me permitido utilizar alguns materiais de seu laboratório em minha pesquisa. Agradeço também aos seus orientados: Maristela, Juliana, Ricardo e Carolina, por terem-me supervisionado com algumas questões experimentais ou por terem contribuído com sugestões em meu trabalho.

À profa. Dra. Márcia Mayer, por ter-me acolhido sempre em seu laboratório, permitindo-me utilizar seus equipamentos, que foram de grande ajuda em minha pesquisa. Agradeço também ao pessoal de seu laboratório: ao Maike, Marcela, Bruno, Lucas e, especialmente, ao Léo, pela gentileza sempre que precisei de alguma colaboração de vocês.

Ao prof. Dr. Chuck Farah, por ter-me cedido gentilmente a coluna de afinidade HiTrap Chelating HP.

Aos professores: Dr. Gabriel Padilla, Dr. Rodrigo Galhardo, Dr. Carlos Menck, Dr. Luis Carlos Ferreira, Dr. Gregório Gomez, Dr. René Schneider e à Dra. Silvana Cai, por terem-me permitido utilizar vários dos equipamentos de seus laboratório ou por terem contribuído com algum material relevante em minha pesquisa.

À Luci Navarro, funcionária do IQ, por sua colaboração em meus sequenciamentos de DNA, e pelas conversas acadêmicas que contribuíram no aprimoramento deles.

Aos funcionários do ICB II: Bete, Gisele, o pessoal do antigo SAT, o pessoal da limpeza, etc., pela gentileza e dedicação em seus trabalhos, os quais também contribuíram para a consecução deste meu trabalho.

À Renata e a dona Teresa, funcionárias da biblioteca do ICB, pelas correções na formatação deste documento e por toda sua gentileza.

À dona Neli, por ser minha mãe de coração no Brasil, por ter-me ajudado em momentos difíceis e por sempre me fazer sentir como um de seus filhos.

Aos meus pais, Pablo e Susana, e aos meus irmãos, Vivi e Alejo, por terem sempre sido meu chão, meu sustento e meu apoio em todos os caminhos de minha vida. Muito obrigado por confiarem em mim e por me fazerem sentir sempre amparado, mesmo estando fisicamente longe.

À Yas, por sua amizade e companhia, por ter sido a pessoa que me recebeu quando cheguei ao Brasil, pela ajuda com todas as questões referentes a minha permanência no país e por nossos papos, que me permitiram relaxar em momentos de alto estresse.

Aos meus melhores amigos: Liz, Natalia, Jenny e Leonardo, pela amizade ao longo do tempo, pelo apoio, motivação e pelos colóquios e risadas que sempre alegraram meus dias. 
Aos meus amigos do ICB: César, Ruth, Vanessa, Roger, Felipe, Camilo, Ángel, Álex e o Luis, pelos momentos divertidos e pelas histórias contadas. 
"Except for hydrogen, all the atoms that make each of us up-the iron in our blood, the calcium in our bones, the carbon in our brains-were manufactured in red giant stars thousands of light-years away in space and billions of years ago in time. We are, as I like to say, starstuff." 


\section{RESUMO}

VILLAMIL, N. F. Análise do metabolismo de polifosfato e do operon pst em Pseudomonas aeruginosa. 2015. 88 f. Dissertação (Mestrado em Microbiologia) Instituto de Ciências Biomédicas, Universidade de São Paulo, São Paulo, 2015.

Pseudomonas aeruginosa é uma $\gamma$-Proteobacteria que habita diversos ambientes, alguns deles, extremamente limitados em nutrientes. A baixa disponibilidade de fosfato solúvel no meio gera a expressão coordenada dos genes do regulon Pho nessa bactéria, entre eles, o operon pst, que codifica um sistema de transporte de fosfato inorgânico (Pi) de alta afinidade. $\mathrm{O}$ último gene do operon pst codifica a proteína PhoU, que não participa do transporte de $\mathrm{Pi}$, mas que, em conjunto com o sistema Pst, atua como repressora da expressão do regulon Pho quando há excesso desse nutriente no meio. A atividade de PhoU está também associada ao metabolismo de polifosfato (poliP), um polímero formado por dezenas ou centenas de unidades de $\mathrm{Pi}$, dado que o nocaute de phoU causa um vasto acúmulo do biopolímero. Neste trabalho é mostrado que o gene $p p k$, que codifica a principal polifosfato quinase de $P$. aeruginosa, e $p p x$, cujo produto é uma exopolifosfatase, têm sua expressão afetada pela mutação phoU. Na ausência desse gene, a transcrição de $p p k$ mais que dobra, enquanto que o nível de transcrição de $p p x$ é quase três vezes menor que o da cepa selvagem. A modulação da expressão dos genes $p p k$ e $p p x$ explica, ao menos em parte, o acúmulo de poliP observado em mutantes phoU. Também, é mostrado que na cepa selvagem, a transcrição de $p p k$ e de $p p x$ aumenta no início da fase estacionária, e que ela não é afetada de forma positiva pela limitação de Pi. Concluiu-se, portanto, que ambos os genes são expressos a partir de promotores constitutivos não regulados por PhoB, o regulador de resposta do regulon Pho. Além disso, determinou-se que ppk é cotranscrito com hemB, um gene envolvido na síntese de porfirinas, com o qual forma um operon. A análise transcricional do operon pst de $P$. aeruginosa mostrou que o transcrito do primeiro gene do operon, pst $S$, é mais abundante que os demais transcritos do operon. Foi também identificado um promotor imediatamente a montante de phoU, o gene mais distal do operon, que estaria contribuindo para a expressão de phoU de forma independente da concentração de Pi no meio. Por fim, determinou-se que as sequências regulatórias Pho box presentes a montante de pst $S$ e a montante de $p s t C$ são funcionais. Esse resultado sugere que a transcrição do operon pst de $P$. aeruginosa deve ocorrer a partir de dois locais diferentes.

Palavras-chave: Polifosfato. ppk. ppx. Operon pst. Fosfato. Pseudomonas aeruginosa. phoU. Regulon Pho. Transportador Pst. Regulação gênica. Pho box. Operon. 


\begin{abstract}
VILLAMIL, N. F. Analysis of the metabolism of polyphosphate and of the pst operon in Pseudomonas aeruginosa. 2015. 88 p. Masters thesis (Microbiology) Instituto de Ciências Biomédicas, Universidade de São Paulo, São Paulo, 2015.

Pseudomonas aeruginosa is a $\gamma$-Proteobacteria inhabiting different environments, some of them, extremely limited in nutrients. The low availability of soluble phosphate in the environment generates the coordinated expression of the Pho regulon genes. The pst operon, that encodes an orthophosphate $(\mathrm{Pi})$ transport system is a member of the Pho regulon. pho $U$, the last gene of the pst operon codes for a protein that does not participate in the transport of $\mathrm{Pi}$, but which, together with the Pst system, represses the expression of the Pho genes when $\mathrm{Pi}$ is in excess. PhoU is also associated with metabolism of polyphosphate (polyP), a polymer consisting of tens or hundreds of $\mathrm{Pi}$ units, once the knockout of pho $U$ results in a huge accumulation of the biopolymer in the cell. Here, it is shown that the $p p k$ gene, that encodes the major polyphosphate kinase, and $p p x$, whose product is an exopolyphosphatase, have their expression affected by the phoU mutation. In the absence of $p h o U, p p k$ transcription increases more than twice, while the level of $p p x$ transcription is only $1 / 3$ of the one presented by the wild-type strain. The effect of the phoU mutation on $p p k$ and $p p x$ expression helps explaining the accumulation of polyP observed in $p h o U$ mutants. It is also shown that the transcription of $p p k$ and $p p x$ increases in the early stationary phase and that it is not affected by $\mathrm{Pi}$ limitation. It is concluded that both genes are expressed from constitutive promoters that are not regulated by $\mathrm{PhoB}$, the response regulator of the Pho regulon. In addition, it was determined that $p p k$ is co-transcribed with hemB, a gene involved in the synthesis of porphyrins, with which it forms an operon. Transcriptional analysis of the pst operon of $P$. aeruginosa showed that the transcript of $p s t S$, the first gene of the operon, is more abundant than that of the other genes. A promoter immediately upstream of phoU, was identified. This promoter contributes to the expression of phoU under Pi-excess. Finally, it was determined that the two Pho boxes, one located upstream of pstS and the other upstream of pstC are functional. This result suggests that transcription of the pst operon of $P$. aeruginosa initiates at two different locations.
\end{abstract}

Keywords: Polyphosphate. ppk. ppx. pst operon. Pseudomonas aeruginosa. phoU. Pho regulon. Pst transporter. Gene regulation. Pho box. Operon. 


\section{LISTA DE ILUSTRAÇÕES}

Figura 1 - Processo de captação e assimilação de Pi ambiental em bactéria. Adaptado de (NEIDHARDT, 1996)

Figura 2 - Estrutura e funcionamento de várias proteínas codificadas por genes pertencentes ao regulon Pho de $\boldsymbol{E}$. coli. PhoE, porina específica para ânions; FA, fosfatase alcalina; UgpB, proteína periplasmática de ligação a G3P; UgpA e UgpE, canais intermembranais para o transporte de G3P; UgpQ, ATPase que energiza o transporte de G3P; PstS, proteína periplasmática de ligação a Pi; PstA e PstC, canais intermembranais para o transporte de Pi; PstB, ATPase que energiza o transporte de $\mathrm{Pi}$; PhoU, produto do gene phoU; PhoR, histidina quinase, e PhoB, regulador de resposta. Adaptado de (TORRIANIGORINI et al., 1994)

Figura 3 - Organização dos genes do operon pst de $\boldsymbol{E}$. coli. As duas Pho box e a sequência -10 a montante de pstS são apresentadas. A seta indica a direção de transcrição do operon.

Figura 4 - Processo de ativação/inativação de PhoB por PhoR, seguido da ativação dos genes do regulon Pho. N e C representam as regiões amino- e carboxi-terminal de PhoB e PhoR. Em limitação de Pi, PhoR autofosforila-se e, a seguir, fosforila PhoB. A fosforilação de PhoB aumenta sua afinidade às sequências Pho box, ativando a transcrição do gene pela interação com a RNA polimerase associada ao fator $\sigma^{70}$. Adaptado de (TORRIANI-GORINI et al., 1994). . . . . . . .

Figura 5 - Organização dos genes do operon pst de $\boldsymbol{P}$. aeruginosa. As duas Pho box e as duas sequências -10 a montante de pstS e também de $p s t C$ são apresentadas. A seta indica a direção de transcrição do operon.

Figura 6 - Organização dos genes $p p k$ e $p p x$ no cromossomo de $P$. aeruginosa. As setas indicam a direção em que é transcrito cada gene. .

Figura 7 - Mecanismo gênico da integração e excisão do backbone do plasmídio não replicativo promotor-Mini-CTX-lacZ em PA14 e o mutante phoU. O sítio attP, presente no plasmídio contendo o promotor clonado, integra-se no cromossomo de PA14 pelo sítio attB por meio da atividade da integrase codificada pelo próprio vetor. Bactérias transformadas são então selecionadas em meio seletivo contendo tetraciclina. Finalmente, a proteína Flp, codificada pelo vetor pFLP2, excisa genes e promotores do plasmídio integrado que, potencialmente, possam interferir na expressão da fusão transcricional. Adaptado de (BECHER; SCHWEIZER, 2000) . . . . . . . . . . . . . . . 
Figura 8 - Metodologia aplicada na construção de cepas de PA14 carregando fusões transcricionais de cópia única no cromossomo. Bactérias de S17-1 carregando o plasmídio promotor-Mini-CTX-lacZ foram conjugadas com PA14. Exconjugantes de PA14 foram selecionados em placas de meio seletivo contendo tetraciclina e ácido nalidíxico. A seguir, as bactérias Tet $^{r}$ foram eletroporadas com o vetor pFLP2, e os transformantes foram selecionados em placa contendo carbenicilina. Finalmente, bactérias $\mathrm{Tet}^{\mathrm{s}} \mathrm{Car}^{\mathrm{r}}$ foram contra-selecionadas em meio Lágar suplementado com sacarose 5\%. Algumas colônias da placa com sacarose $5 \%$ foram repicadas em placas com antibiótico, X-gal e XP para confirmar a excisão do backbone do vetor, a cura do plasmídio pFLP2 e a atividade basal da $\beta$-galactosidase, e, no caso do mutante phoU, a atividade da FA.

Figura 9 - Sequência nucleotídica da porção 3' do gene hemB e 5' de $p p k$ nas cepas PAO1 e 8830 de $P$. aeruginosa. Aparecem sublinhadas as sequências Shine-Dalgarno putativas próximas ao códon de iniciação de tradução de PPK de cada cepa (ATG ou GTG). Na sequência correspondente à cepa 8830 aparece indicada a região promotora de $p p k$ : são mostrados o sítio de início da transcrição (TSS), determinado por primer extension (ZAGO et al., 1999), e os elementos putativos -35 e -10 reconhecidos pelo fator $\sigma^{\mathrm{E}}$. A sequência de aminoácidos de PPK predita é apresentada em baixo da sequência nucleotídica. Os números ao lado indicam o comprimento da sequência, e dentro de círculos cinzas aparecem marcados os SNPs encontrados. . . . . . . . . . . .

Figura 10 - Detecção do transcrito $\boldsymbol{h e m B}$ - $\boldsymbol{p} \boldsymbol{p} \boldsymbol{k}$. Em (a) são ilustrados os sítios de anelamento dos oligonucleotídeos utilizados na análise, assim como os tamanhos esperados dos produtos de amplificação correspondentes à etapa de $\mathrm{PCR}$ convencional. A imagem não está em escala. Em (b) observa-se o gel de agarose $1 \%$ com os produtos finais da reação de RT-PCR. A) produto hemB-ppk; B) produto hemB; C) produto $p p k$. Controles negativos: oligonucleotídeos PA14-hemB $(g)$-F/PA14hemB(g)-R: D) RT-PCR sem transcriptase reversa; E) RT-PCR sem RNA molde; oligonucleotídeos PA14- $p k$ (g)-F/PA14- $p k(g)-\mathrm{R}: \mathrm{F}) \mathrm{RT}$ PCR sem transcriptase reversa; G) RT-PCR sem RNA molde. . . . .

Figura 11 - Possível organização dos genes hemB e ppk no cromossomo de PA14. São mostradas as regiões clonadas no vetor mini-CTXlacZ para a avaliação de atividade promotora mediante ensaios de $\beta$-galactosidase. Os círculos brancos representam regiões intergênicas.

Figura 12 - Avaliação da atividade de dois possíveis promotores do gene $\boldsymbol{p p} \boldsymbol{k}$ em meio DPMM suficiente $(\mathbf{1} \mathbf{~ m M})$ e limitado $(0,2 \mathrm{mM})$ em Pi. Bactérias carregando as inserções cromossomais $($ hemB-ppk) $P$ lacZ e ${ }_{p p k} P$-lac $Z$ foram analisadas após 4 e 8 horas de crescimento em relação à atividade da $\beta$-galactosidase e fosfatase alcalina. Os valores apresentados e o desvio padrão da média correspondem a réplicas de três experimentos independentes. . . . . . . . . . . . . . . 
Figura 13 - Efeito de PhoU sobre a expressão de ${ }_{(h e m B-p p k)} \boldsymbol{P}-\boldsymbol{l a c} \boldsymbol{Z}$ e ${ }_{p p x} \boldsymbol{P}$ lac $\boldsymbol{Z}$. A cepa selvagem PA14 e o mutante phoU, carregando as inserções cromossomais $\left(\right.$ hemB-ppk) $P$-lac $Z$ e ${ }_{p p x} P$-lacZ, foram cultivadas em meio DPMM suficiente em Pi $(1 \mathrm{mM})$. A expressão das fusões foi avaliada a cada 2 horas em ensaios de $\beta$-galactosidase. Os valores apresentados e o desvio padrão da média correspondem a três experimentos independentes. 57

Figura 14 - Sequências consenso na região promotora necessárias à regulação do gene $\boldsymbol{p} \boldsymbol{p} \boldsymbol{x}$ de $\boldsymbol{P}$. aeruginosa PAO1. Fonte: (GALLARATO et al., 2014) . . . . . . . . . . . . . . . . . . . . . . . . 58

Figura 15 - Efeito de PhoU sobre a expressão de ${ }_{(h e m B-p p k)} \boldsymbol{P}$-lac $\boldsymbol{Z}$ e ${ }_{p p x} \boldsymbol{P}$ lac $Z$ em diferentes condições de crescimento. Bactérias carregando as inserções cromossomais (hemB-ppk) $P$-lacZ e ${ }_{p p x} P$-lacZ foram cultivadas em meio DPMM $+\mathrm{Pi}$, $-\mathrm{Pi}$ e $-\mathrm{N}$ a $37{ }^{\circ} \mathrm{C}$ e ensaiadas nos tempos de 4 e 8 horas para a atividade da $\beta$-galactosidase e fosfatase alcalina. Os valores apresentados e o desvio padrão da média correspondem a três experimentos independentes.

Figura 16 - Alinhamento das sequências Pho box putativas presentes nos promotores de $p p x$ e phoX das espécies $P$. aeruginosa e $P$. fluorescens, respectivamente. Foi usada a ferramenta BLAST (ALTSCHUL et al., 1990) para o alinhamento das sequências. Fonte das sequências: (GALLARATO et al., 2014; MONDS et al., 2006).

Figura 17 - Operon pst de $\boldsymbol{P}$. aeruginosa apresentando as regiões de amplificação por PCR das sondas de DNA utilizadas no ensaio de northern blot. A seta tracejada representa a transcrição da espécie de mRNA detectada correspondente ao transcrito de $p s t S$.

Figura 18 - Análise do operon pst por northern blot. Cada sonda biotinilada utilizada para hibridizar com os respectivos transcritos aparece identificada na membrana. O RNA foi extraído de culturas de PA14 cultivadas em meio DPMM em suficiência $(+\mathrm{Pi})$ ou deficiência $(-\mathrm{Pi})$

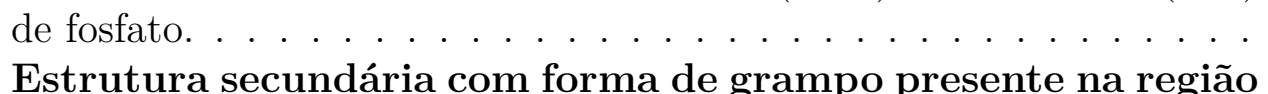

Figura 19 - Estrutura secundária com forma de grampo presente na região
intergênica entre pstS e pstC. O grampo apresenta uma haste de GCs e 3 uracilas próximas da região 3' do mRNA. . . . . . . . . . . . .

Figura 20 - Esquema do operon pst de PA14 no qual aparece indicada a região pstB-phoU amplificada por PCR e clonada no MiniCTX-lacZ. A atividade promotora dessa região foi avaliada através de ensaios de $\beta$-galactosidase. . . . . . . . . . . . . . . . . .

Figura 21 - Avaliação da atividade promotora na região imediatamente a montante de $\boldsymbol{p h o} \boldsymbol{U}$. Bactérias foram cultivadas em meio DPMM +Pi e -Pi a $37^{\circ} \mathrm{C} .4$ e 8 horas após o início do crescimento, alíquotas de bactérias foram coletadas e avaliadas em ensaios de $\beta$-galactosidase. Foi também testada a atividade da fosfatase alcalina de cada cultura. Os valores apresentados e o desvio padrão da média correspondem a três experimentos independentes. . . . . . . . . . . . . . . .

Figura 22 - Mini ensaio de indução de PhoB-His. SDS-PAGE (15\%) com os extratos de proteína das culturas de BL21 (DE3) crescidas a 30 e $37^{\circ} \mathrm{C}$. As culturas induzidas foram tratadas com IPTG a uma concentração de $1 \mathrm{mM}$ por 4 horas. 
Figura 23 - Purificação de PhoB-His por cromatografia de afinidade por íons metálicos imobilizados. A coluna de afinidade carregada com $\mathrm{Ni}^{2+}$ foi equilibrada com tampão de ligação $(50 \mathrm{mM}$ de tris $\cdot \mathrm{HCl}(\mathrm{pH} 8,0)$, $200 \mathrm{mM}$ de $\mathrm{NaCl}$ e $10 \mathrm{mM}$ de imidazol). Uma cultura de BL21 (DE3), cultivada a $30{ }^{\circ} \mathrm{C}$ por 4 horas em LB suplementado com $0,5 \mathrm{mM}$ de IPTG, foi lisada, clarificada e inserida na coluna de afinidade. Depois de várias lavagens com tampão de ligação, a proteína foi eluída com tampão de eluição contendo imidazol (500 mM). (a) O cromatograma apresentado corresponde às diferentes frações de PhoB-His eluídas da coluna. (b) Gel de poliacrilamida em condições desnaturantes (SDSPAGE 15\%) com as frações de eluição (2-10) da purificação de PhoB-His. 69

Figura 24 - Ensaio de ligação in vitro de PhoB nas regiões promotoras dos genes pst $\boldsymbol{S}$, pst $\boldsymbol{C}$ e $\boldsymbol{p} \boldsymbol{p} \boldsymbol{x}$. São apresentados os resultados dos ensaios de retardo da mobilidade eletroforética no estudo da ligação da proteína PhoB-His em três promotores de interesse. Os sítios de ligação encontram-se centrados em suas sequências Pho box putativas. Cada sonda foi incubada com $0 ; 0,1 ; 0,3 ; 0,5 ; 0,7 ; 0,9 ; 5 ; 10 ; 15$ e $20 \mu \mathrm{M}$ de PhoB-His como mostrado. O DNA livre e o complexo PhoB-His-DNA foram nomeados como L e C, respectivamente. Cada gel foi visualizado por autorradiografia (esquerda) e por análise com phosphorimager (direita). . . . . . . . . . . . . . . . . .

Figura 25 - Determinação da faixa de linearidade do espectrofotômetro de microplacas Epoch ${ }^{\mathrm{TM}}$ nos comprimentos de onda de 420 e $600 \mathrm{~nm}$. Foram preparadas diluiçoes seriadas a partir de uma solução de ONP e de uma cultura de PA14 crescida overnight em meio LB. Os valores de $\mathrm{DO}_{420}$ e de $\mathrm{DO}_{600}$ foram então determinados no espectrofotômetro de placas. . . . . . . . . . . . . . . . . . . . . .

Figura 26 - Comparação do crescimento de culturas de $\boldsymbol{P}$. aeruginosa PA14 crescidas em tubo de ensaio e em microplaca de 24 poços de 2,2 ml. As bactérias foram cultivadas em meio DPMM +Pi por 10 horas a $37^{\circ} \mathrm{C}$ sob agitação de $170 \mathrm{rpm}$. A $\mathrm{DO}_{600}$ foi determinada a cada 2 horas em um espectrofotometro de microplacas. Os dados representam o resultado de um único experimento. 


\section{LISTA DE TABELAS}

Tabela 1 - Cepas e plasmídios utilizados neste trabalho . . . . . . . . . . . . . 35

Tabela 2 - Oligonucleotídeos utilizados neste trabalho . . . . . . . . . . 36 


\section{LISTA DE ABREVIATURAS E SIGLAS}

(p)ppGpp guanosina pentafosfato e tetrafosfato

Amp

ampicilina

ATP

trifosfato de adenosina

AttB

sítio de ligação no cromossomo bacteriano

AttP

sítio de ligação localizado no DNA do fago

BLAST

basic local alignment search tool

Car

carbenicilina

cDNA

DNA complementar

$\mathrm{CPM}$

contagem por minuto

CTAB

brometo de cetiltrimetilamônio

DNA

ácido desoxirribonucleico

dNTP

desoxirribonucleotídeos trifosfatados

DO

densidade óptica

DPMM

meio mínimo definido de fosfato

DTT

ditriotreitol

EDTA

ácido etilenodiaminotetraacético

EMSA

ensaio de retardo da mobilidade eletroforética

FA

enzima fosfatase alcalina

Flp

enzima flipase

IPTG

isopropil- $\beta$-D-1-tiogalactopiranosídeo

$\mathrm{kb}$

quilobases

$\mathrm{kDa}$

quilodaltons

$\mathrm{kpb}$

quilopares de bases

LB

caldo lisogênico

mRNA

RNA mensageiro

nt

nucleotídeos

ONP

o-nitrofenol

ONPG

o-nitrofenil- $\beta$-D-galactopiranosídeo 
ORF quadro aberto de leitura

$\mathrm{pb}$

pares de bases

PCR reação em cadeia da polimerase

$\mathrm{Pi}$

fosfato inorgânico

PNK

enzima polinucleotídeo quinase

$\mathrm{pNPP}$

p-nitrofenilfosfato

PoliP

polifosfato

PPK

enzima polifosfato quinase

PPX

enzima exopolifosfatase

RNA

ácido ribonucleico

RNase

ribonuclease

RT-PCR reação da transcriptase reversa seguida de PCR

SDS

dodecil sulfato de sódio

SDS-PAGE eletroforese em gel de poliacrilamida contendo SDS

SNP

polimorfismo de nucleotídeo único

SSC

tampão salino de citrato de sódio

TBE

tampão tris-borato-EDTA

TCEP

tris-[2-carboxietil]-fosfina

Tet

tetraciclina

TSS

sítio de início da transcrição

X-gal

5-bromo-4-cloro-3-indolil- $\beta$-D-galactopiranosídeo

$\mathrm{XP}$

5-bromo-4-cloro-3'-indolilfosfato 
SUMÁRIO

Página

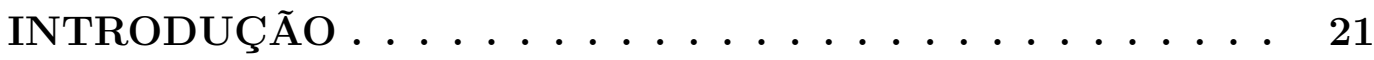

REFERENCIAL TEÓRICO . . . . . . . . . . . . . 23

2.1

Captação de Pi e os processos de regulação gênica envolvidos

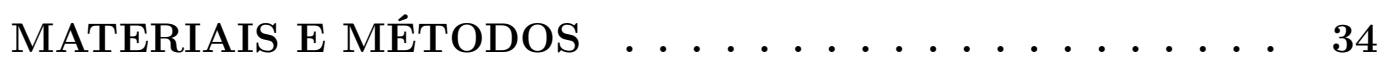
com o vetor Mini-CTX-lacZ, no cromossomo de PA14 e do mutante $p h o U \ldots \ldots \ldots \ldots \ldots \ldots \ldots$

Avaliação da faixa de linearidade do espectrofotômetro de microplacas Epoch $^{\mathrm{TM}}$

Ensaios de $\beta$-galactosidase em microplaca de 96 poços . Determinação do padrão de transcrição do operon pst de Pseudomonas aeruginosa por northern blot

Transferência do RNA para a membrana . . . . . . . . . . . 45

Preparação das sondas . . . . . . . . . . . . . . . . . . 45

Prehibridização, hibridização e detecção . . . . . . . . . . . . . 45 
4.15.4 Purificação de PhoB-His recombinante por cromatografia de afinidade por íons metálicos imobilizados (IMAC) . . . . . . . . . . . . . . . 48

4.15.5 Fosforilação de PhoB-His . . . . . . . . . . . . . . . . . . . 49

4.15.6 Marcação das extremidades dos fragmentos de DNA com $\left[\gamma_{-}{ }^{32} \mathrm{P}\right]$-ATP 49

4.15.7 Ensaio de retardo da mobilidade eletroforética (EMSA) . . . . . . . . 49

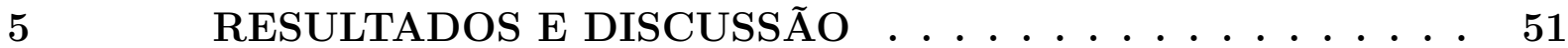

$5.1 \quad$ Identificação do promotor principal do gene $p p k$ de PA14 . . 51

5.2 Avaliação do efeito da mutação phoU sobre a regulação dos genes $p p k$ e $p p x$ de PA14 . . . . . . . . . . . . . . . . 56

5.3 Determinação do padrão de transcrição do operon $p s t$ de $P s e u-$ domonas aeruginosa . . . . . . . . . . . . . 63

5.3.1 Detecção dos transcritos de pst por northern blot . . . . . . . . . . . 63

5.3.2 Identificação de um promotor alternativo a montante de phoU . . . . 66

5.4 Avaliação da funcionalidade das sequências Pho box do operon pst e da possível regulação de PhoB sobre o gene $p p x$ de PA14 68 DO ESPECTROFOTÔMETRO DE MICROPLACAS EPOCH ${ }^{\mathrm{TM}} \ldots \ldots \ldots \ldots$

ANEXO B - COMPARAÇÃO DO CRESCIMENTO DE CULTURAS DE PA14 EM TUBO DE ENSAIO E EM MICROPLACA DE 24 POÇOS DE 2,2 ML 


\section{INTRODUÇÃO}

Fósforo é um nutriente essencial para todas as formas de vida conhecidas, constituindo aproximadamente 3\% do peso seco de todos os organismos (WHITE; METCALF, 2007). O fósforo é encontrado na natureza principalmente em sua forma química mais oxidada, $\left(\mathrm{PO}_{4}^{3-}\right)$, designada ortofosfato ou simplesmente fosfato inorgânico (Pi). Grande parte do Pi que está na natureza encontra-se na forma de sais minerais insolúveis. Apesar da relativa abundância do nutriente, sua biodisponibilidade no ambiente é baixa, sendo um dos elementos que mais restringe a produtividade biológica em sistemas naturais, tanto aquáticos como terrestres (ANBA et al., 1990; TURNER et al., 2005).

A título de exemplo, na agricultura o Pi deve ser suplementado por meio do uso de fertilizantes. Parte do Pi procedente acaba precipitando, formando complexos insolúveis com componentes do solo, e sofrendo lixiviação. A drenagem desses compostos para corpos de água de ambientes naturais traz como consequência o aumento da concentração de fósforo, sendo esse o principal fator desencadeador do processo de eutrofização em ecossistemas aquáticos (CAMPILLO et al., 1999; YEOMAN et al., 1988). Outro fator significativo que contribui para o aumento nocivo de fósforo nesses ambientes naturais é o lançamento deliberado de rejeitos líquidos, detergentes e outros compostos que contêm fósforo em suas formulações (YEOMAN et al., 1988).

Antes de serem liberadas na natureza, águas residuárias devem passar por um tratamento adequado, que inclui a remoção de fósforo. O tratamento biológico das águas de rejeitos fundamenta-se na capacidade que microrganismos têm em captar grandes quantidades de $\mathrm{Pi}$, armazenando-o principalmente na forma de polifosfato (poliP) (CHRISTENSSON et al., 1998). Parte da remoção biológica do fósforo deve-se à atividade de bactérias de diversos gêneros: Acinetobacter spp. (WENTZEL et al., 1986), Aeromonas, Pseudomonas, Xanthomonas, Moraxella, Bacillus e Corynebacterium (HIRAISHI; MORISHIMA, 1990; LIN-LIN et al., 2007; STREICHAN et al., 1990).

Considerando-se a técnica de remoção biológica de fósforo como uma alternativa apropriada aos processos clássicos de remoção desse nutriente de águas residuárias, é desejável aprimorar a capacidade de armazenamento de Pi na forma de poliP em bactérias. De fato, já foram descritas cepas modificadas de E. coli com capacidade de captar 10 vezes mais Pi e armazená-lo na forma de poliP (HARDOYO et al., 1994; KATO et al., 1993; OHTAKE et al., 1994). A identificação e estudo de bactérias com maior capacidade de 
captação de Pi será importante para o aperfeiçoamento dos processos de remoção desse nutriente em áreas contaminadas. Desta forma, o presente trabalho visa contribuir para o entendimento dos fatores que regem as bases moleculares da síntese e degradação de poliP e captação de $\mathrm{Pi}$, contribuindo para a compreensão dos processos associados ao metabolismo de Pi em P. aeruginosa. 


\section{REFERENCIAL TEÓRICO}

\subsection{Captação de Pi e os processos de regulação gênica envolvidos}

Em bactérias, é possível encontrar fósforo na estrutura de diversas biomoléculas, sendo um constituinte essencial de ácidos nucleicos, carboidratos complexos, proteínas modificadas e fosfolipídios. Ele também está associado a processos de metabolismo energético, em virtude da presença de ligações fosfoanidridas de alta energia, como em moléculas de ATP, fosfoenolpiruvato e acetilfosfato (NEIDHARDT, 1996).

Três tipos de compostos são utilizados por bactérias como fonte principal de P: ortofosfato (Pi), a fonte de P predileta, organofosfatos e fosfonatos (NEIDHARDT, 1996). Independentemente da natureza química do nutriente, seu processo de assimilação compreende duas etapas: a captação, na qual atua algum tipo de transporte ativo, e o metabolismo, no qual o Pi irá geralmente formar moléculas de ATP, que será utilizado como substrato em diversas rotas anabólicas e catabólicas (Figura 1).

Devido à baixa disponibilidade de fósforo solúvel na natureza, as bactérias desenvolveram respostas adaptativas que lhes conferem a capacidade de captar Pi, e outras fontes alternativas de $\mathrm{P}$, de forma eficiente, mesmo quando sua concentração no meio é baixa. A adaptação bacteriana ao crescimento em baixas concentrações de Pi ambiental é executada de maneira coordenada pelos genes pertencentes ao regulon Pho (Figura 2). O controle deste conjunto de genes por Pi extracelular representa o modelo de um sistema regulatório de dois componentes.

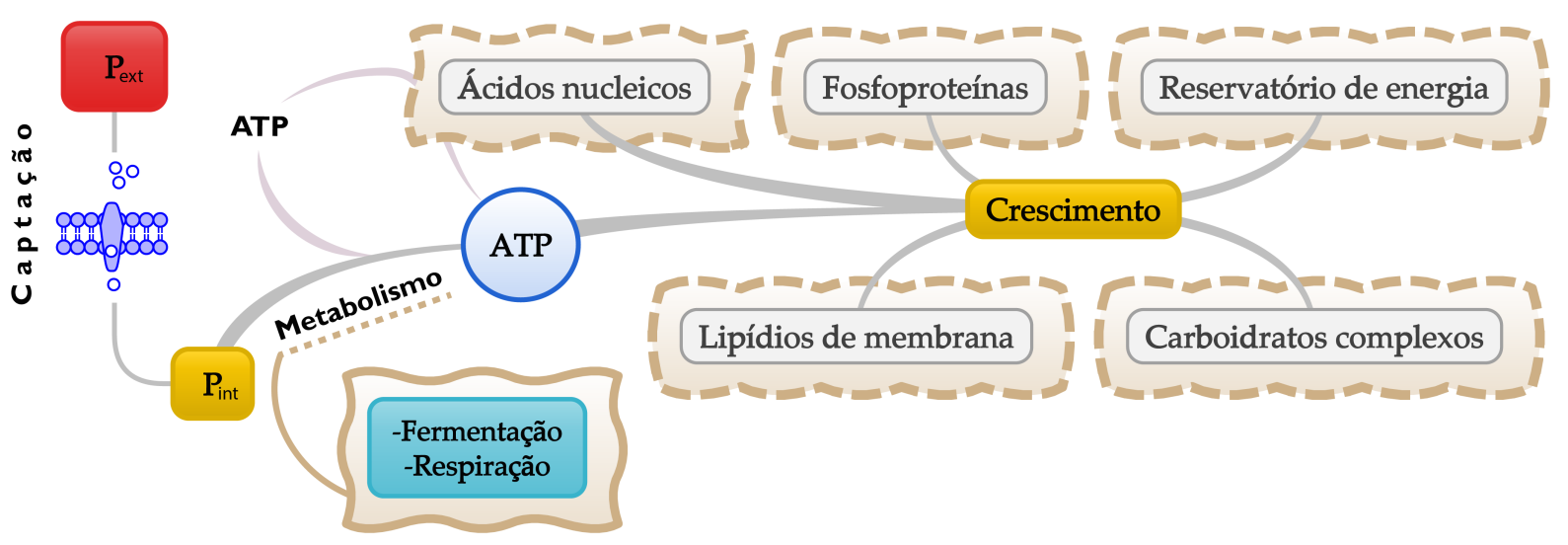

Figura 1 - Processo de captação e assimilação de Pi ambiental em bactéria. Adaptado de (NEIDHARDT, 1996). 


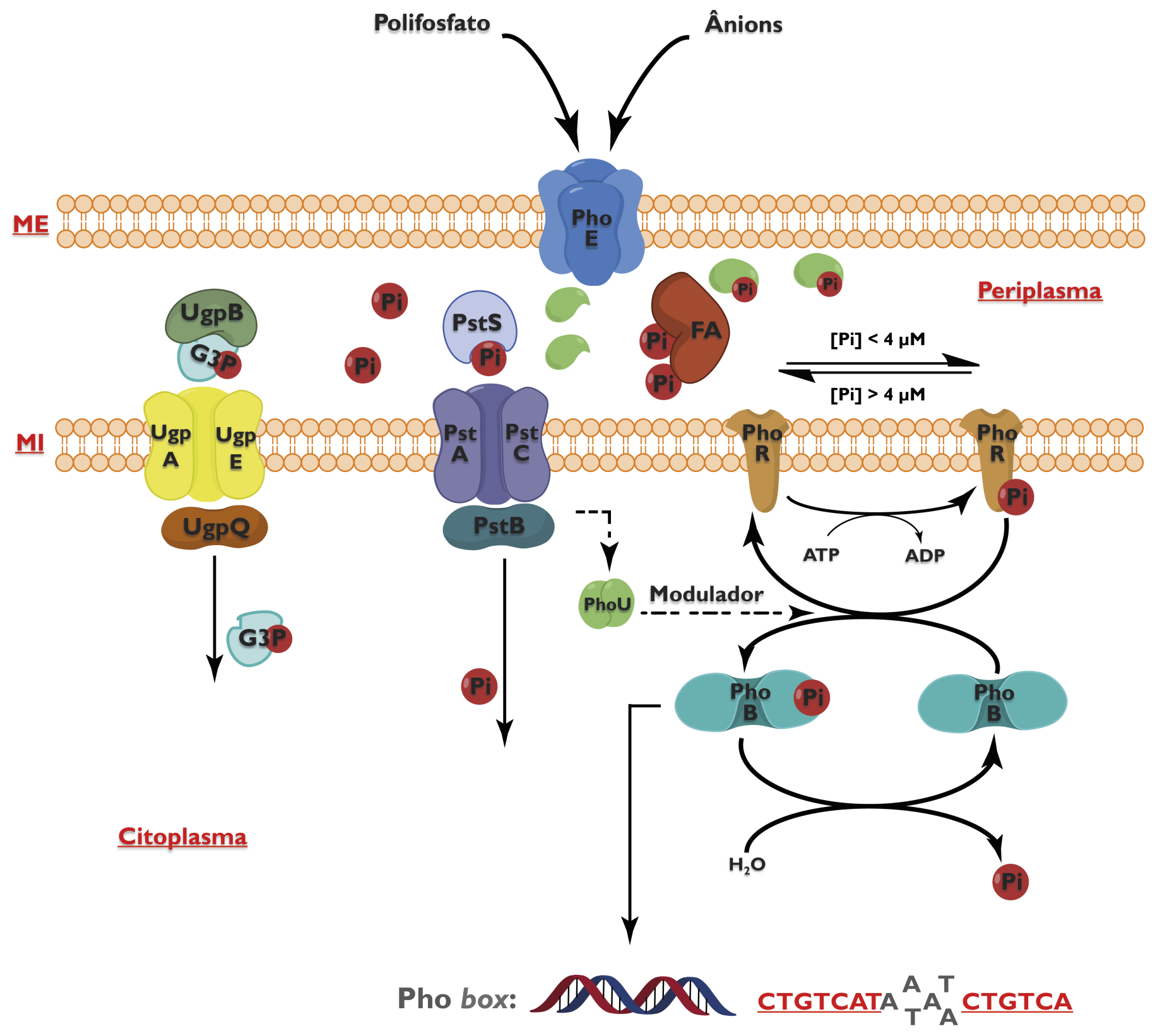

Figura 2 - Estrutura e funcionamento de várias proteínas codificadas por genes pertencentes ao regulon Pho de $\boldsymbol{E}$. coli. PhoE, porina específica para ânions; FA, fosfatase alcalina; UgpB, proteína periplasmática de ligação a G3P; UgpA e UgpE, canais intermembranais para o transporte de G3P; UgpQ, ATPase que energiza o transporte de G3P; PstS, proteína periplasmática de ligação a Pi; PstA e PstC, canais intermembranais para o transporte de Pi; PstB, ATPase que energiza o transporte de Pi; PhoU, produto do gene phoU; PhoR, histidina quinase, e PhoB, regulador de resposta. Adaptado de (TORRIANI-GORINI et al., 1994). 


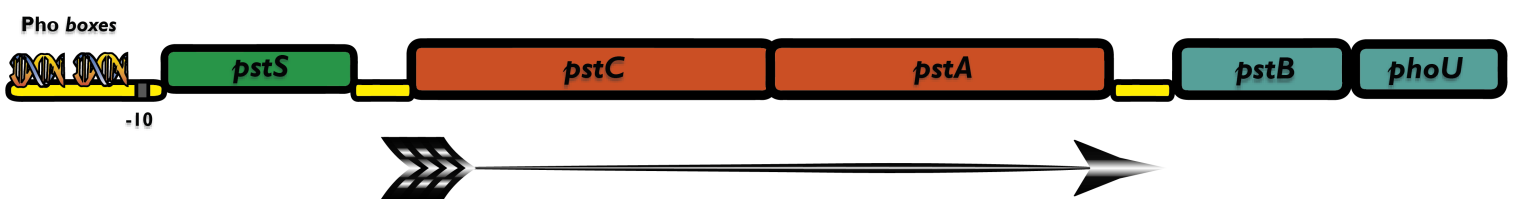

Figura 3 - Organização dos genes do operon pst de $\boldsymbol{E}$. coli. As duas Pho box e a sequência -10 a montante de $p s t S$ são apresentadas. A seta indica a direção de transcrição do operon.

Em E. coli, o regulon Pho é formado por pelo menos 31 genes distribuídos em nove unidades transcricionais, espalhadas aleatoriamente no cromossomo da bactéria (NEIDHARDT, 1996). Entretanto, a descoberta de genes novos que respondem ao estímulo de limitação de Pi indicam que a lista de genes pertencentes ao regulon Pho tende a aumentar (BAEK; LEE, 2006; HAN et al., 1999). Os membros do regulon Pho melhor estudados são: (i) PhoE, uma porina específica para ânions (KORTELAND et al., 1982; KORTELAND et al., 1984); (ii) FA, uma fosfatase alcalina periplasmática (TORRIANI, 1960); (iii) o sistema Ugp, que forma um transportador específico de glicerol-3fosfato (G3P) e de glicerofosfodiésteres (SCHWEIZER; BOOS, 1984; YANG et al., 2009); (iv) as proteínas envolvidas no transporte e utilização de fosfonatos codificadas pelo operon phnCDEFGHIJKLMNOP (MAKINO et al., 1991; WACKETT et al., 1987); (v) PhoU e as proteínas que formam o transportador de Pi de alta afinidade, todas codificadas pelo operon pst; e (vi) as proteínas PhoB e PhoR.

No regulon Pho, o sensoriamento das concentrações de Pi ambiental e o processo de transdução de sinal demanda a atividade conjunta de sete proteínas: o sistema de dois componentes PhoB/PhoR e as cinco proteínas codificadas pelo operon pst.

Além de participar da regulação de Pho, Pst forma um sistema de transporte do tipo ABC (ATP-binding cassete). Sua atividade é exercida por meio das proteínas: PstS, uma proteína periplasmática de elevada afinidade por Pi, PstC e PstA, duas proteínas integrais de membrana através das quais é conduzido Pi, e PstB, uma ATPase associada à membrana citoplasmática, que hidroliza ATP para gerar a energia para o transporte [Chan and Torriani, 1996]. Em E. coli, os genes que codificam as proteínas do transportador Pst encontram-se agrupados formando um operon de cinco genes denominado operon pst (Figura 3). Os quatro genes proximais do operon (pstS, pstC, pstA e pstB) codificam o transportador de Pi. O gene mais distal codifica a proteína PhoU. Esta é uma proteína associada à membrana citoplasmática e que não participa da captação de Pi. A função 
exata de PhoU é desconhecida.

A expressão dos genes do regulon Pho é controlada pelo sistema de dois componentes PhoB/PhoR. PhoR é a histidina quinase sensora (MAKINO et al., 1986) e, PhoB, o regulador de resposta. Em E. coli, quando Pi está em excesso, PhoR, que é uma proteína bifuncional, desfosforila PhoB, inativando-a (CARMANY et al., 2003; TORRIANIGORINI et al., 1994). Quando a concentração de Pi no ambiente extracelular é menor que $4 \mu \mathrm{M}$ (HOCH; SILHAVY, 1995), PhoR autofosforila-se e, em seguida, transfere o grupo fosforil a PhoB (MAKINO et al., 1989; TORRIANI-GORINI et al., 1994). Uma vez fosforilada, PhoB liga-se às regiões promotoras de genes que apresentam sequências consenso características, conhecidas como Pho box. Por fim, a interação de PhoB com o fator $\sigma^{70}$ associado à RNA polimerase propicia o início da transcrição desses genes (MAKINO et al., 1988) (Figura 4).

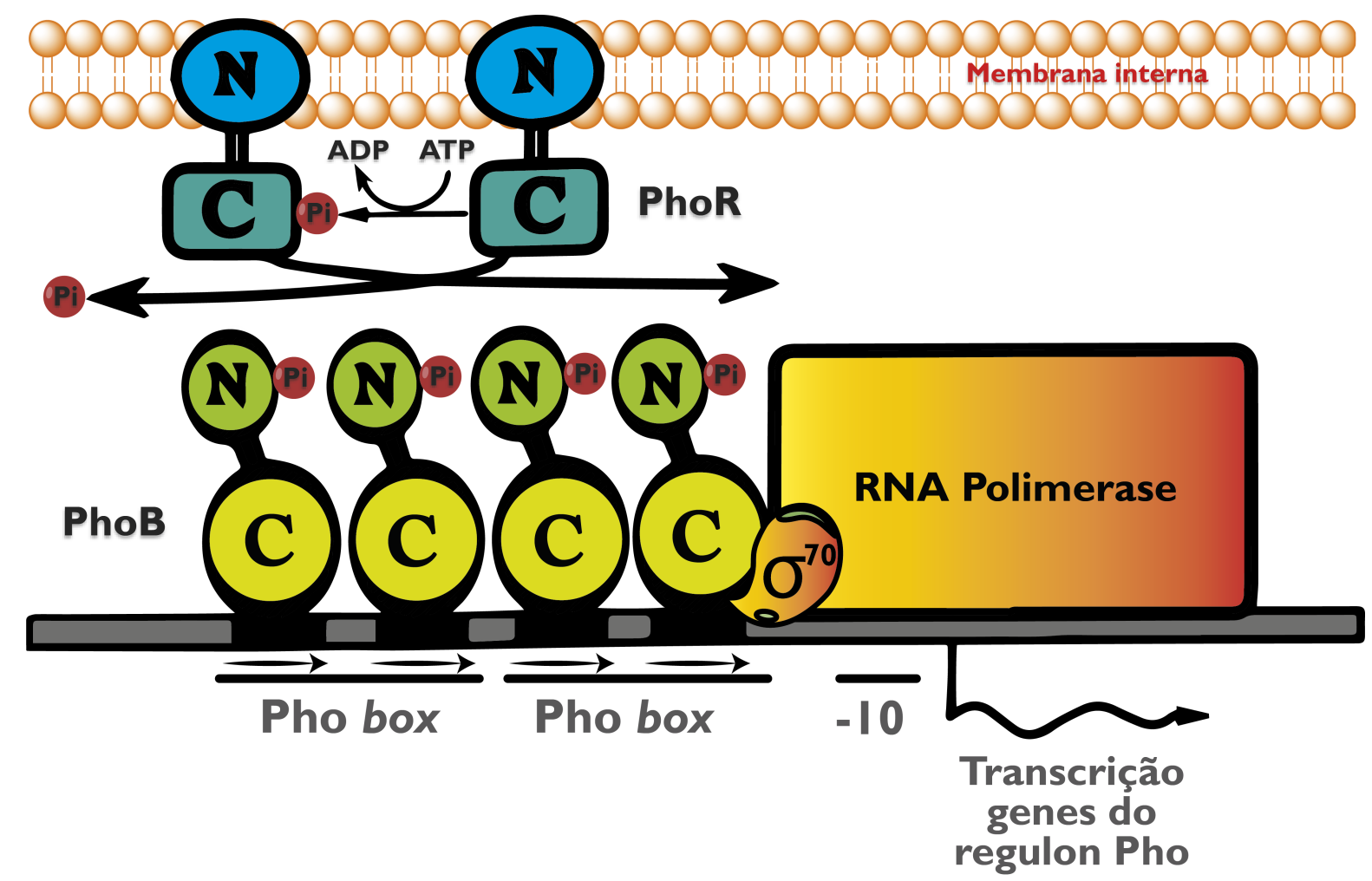

Figura 4 - Processo de ativação/inativação de PhoB por PhoR, seguido da ativação dos genes do regulon Pho. $\mathrm{N}$ e $\mathrm{C}$ representam as regiões amino- e carboxi-terminal de PhoB e PhoR. Em limitação de Pi, PhoR autofosforila-se e, a seguir, fosforila $\mathrm{PhoB}$. A fosforilação de $\mathrm{PhoB}$ aumenta sua afinidade às sequências Pho box, ativando a transcrição do gene pela interação com a RNA polimerase associada ao fator $\sigma^{70}$. Adaptado de (TORRIANI-GORINI et al., 1994). 
Na levedura S. cerevisiae, o Pi intracelular contribui para a regulação da expressão de genes implicados na captação e assimilação de Pi (AUESUKAREE et al., 2004). No entanto, em bactérias isso não acontece, pois não há flutuações significativa nos níveis de Pi intracelular que antecedam a ativação do regulon Pho (TORRIANI-GORINI et al., 1994). Portanto, se o Pi citoplasmático não tem efeito sobre o regulon Pho, como o sinal de carência de Pi chega a PhoR?

Ainda não se compreende de modo exato como PhoR recebe o sinal que estimula a sua ativação, nem como consegue modular as atividades de quinase e fosfatase. Porém, sendo PhoR uma histidina quinase desprovida de domínio sensor periplasmático (CARMANY et al., 2003), acredita-se que ela detecta Pi de maneira indireta: pela interação de seu domínio citoplasmático com as proteínas que compõem o transportador Pst, via PhoU (GARDNER et al., 2014; HSIEH; WANNER, 2010).

\subsection{Polifosfato}

Polifosfato é uma molécula que constitui a forma polimérica de Pi, sendo formada por monômeros unidos de maneira linear através de ligações fosfoanidridas. Longas moléculas de poliP foram observadas em organismos procarióticos e eucarióticos (KULAEV et al., 2005). Em bactérias, o poliP pode formar complexos com diversos cátions de importância biológica, como $\mathrm{Ca}^{2+}, \mathrm{Mg}^{2+}$ e $\mathrm{K}^{+}$, e também com cátions de metais pesados, como $\mathrm{Sr}^{2+}$, $\mathrm{Ba}^{2+}$ e $\mathrm{Mn}^{2+}$. Por intermédio desses íons divalentes o poliP consegue formar também complexos celulares maiores com moléculas de ácidos nucleicos (i.e., RNA ou DNA) ou proteínas (KULAEV et al., 2005).

A possibilidade de estabelecer complexos com diferentes moléculas biológicas importantes sugere que o biopolímero desempenha funções diversas. Entre elas, podemos citar: (a) fonte de energia e doador de Pi em reações de metabolismo energético (VEEN et al., 1994); (b) reservatório de Pi (HARDOYO et al., 1994; KATO et al., 1993; OHTAKE et al., 1994); e, especialmente, (c) regulação de diferentes processos bacterianos, tais como a adaptação a diferentes tipos de estresses ambientais e nutricionais (GRAY et al., 2014; GRAY; JAKOB, 2015; GRILLO-PUERTAS et al., 2014; KURODA et al., 1999; RAO; KORNBERG, 1996); a sobrevivência na fase estacionária, via ativação do fator $\sigma$ RpoS (SHIBA et al., 1997), que coordena a resposta geral ao estresse; e, a virulência e patogenicidade (RASHID et al., 2000b; RASHID; KORNBERG, 2000). 
No metabolismo de poliP estão envolvidas principalmente duas proteínas: PPK, uma polifosfato quinase, e PPX, uma exopolifosfatase. PPK é uma proteína que sintetiza longas cadeias de poliP (i.e., de 750 a 1000 resíduos de Pi) exclusivamente a partir de ATP em um mecanismo de síntese processivo (AHN; KORNBERG, 1990; RAO et al., 1985; ROBINSON; WOOD, 1986). A enzima utiliza iniciadores de poliP curtos (i.e., 6-80 resíduos de Pi) gerando exclusivamente moléculas de alto peso molecular (KORNBERG et al., 1956; ROBINSON et al., 1987). No entanto, o mecanismo desse processo ainda não foi plenamente elucidado. PPK também consegue catalisar a reação contrária (i.e., a síntese de ATP a partir de poliP) (AHN; KORNBERG, 1990; KORNBERG, 1957; KURODA; KORNBERG, 1997; MURATA et al., 1988). PPX, por sua vez, hidrolisa longas moléculas de poliP a partir da extremidade da molécula em um processo eminentemente processivo (AKIYAMA et al., 1993; BOLESCH; KEASLING, 2000). Em condições de crescimento normal, a atividade conjunta das duas proteínas consegue manter em equilíbrio os níveis intracelulares de poliP na bactéria.

Em E. coli, as proteínas PPK e PPX são codificadas pelos genes $p p k$ e $p p x$, respectivamente, os quais são cotranscritos e formam, portanto, um operon. (AKIYAMA et al., 1993; KATO et al., 1993). Embora na atualidade exista informação razoável sobre os diferentes estresses ambientais que geram a síntese e o acúmulo de poliP nessa bactéria, pouco é conhecido quanto à expressão dos genes $p p k$ e $p p x$. Foi constatado que a limitação de purinas, em mutantes purF, cujo gene codifica una enzima envolvida na rota biosintética de nucleotídeos púricos, parece induzir a expressão do operon ppk-ppx (JUNG et al., 2012). Além disso, a deficiência de Pi e aminoácidos no meio de cultura também estimula a expressão desse operon (JUNG et al., 2012). Contudo, a atividade desses genes não parece ser dependente de PhoB (DIEN; KEASLING, 1999; MOROHOSHI et al., 2002; NEIDHARDT, 1996)

\subsection{A proteína PhoU}

A exata função da proteína PhoU ainda é desconhecida. Ensaios com o sistema de interação duplo-híbrido mostraram que PhoU interage com PhoR e com o transportador Pst (GARDNER et al., 2014). Surpreendentemente, não existe nenhuma referência de outros transportadores $\mathrm{ABC}$ bacterianos que apresentem uma proteína PhoU análoga (MUDA et al., 1992). 
Em E. coli, PhoU é uma proteína periférica de baixo peso molecular (i.e., 27 kDa) associada à membrana citoplasmática (NAKATA et al., 1984), que pertence à superfamília de proteínas PhoU. Pesquisas desenvolvidas com mutantes $\Delta$ phoU relacionaram a atividade de PhoU com outros processos biológicos:

1. Defeitos no crescimento: o mutante $\Delta$ pho $U$ apresenta menor taxa de crescimento e rendimento celular. Esse fenótipo pode ser suprimido se houver uma mutação em algum dos genes que codifica o sistema Pst (pstSCAB) ou em phoB. Isso acontece, possivelmente, porque, na ausência de phoU, a expressão constitutiva do transportador Pst é tóxica para a bactéria (STEED; WANNER, 1993). O motivo dessa toxicidade ainda é desconhecido. Porém, resultados preliminares obtidos em nosso laboratório com o mutante phoU de P. aeruginosa mostraram que o excesso de $\mathrm{Pi}$ acumulado pela bactéria estaria quelando íons de magnésio, necessários à síntese proteica e ao funcionamento de diversas enzimas. Uma hipótese seria a de que na presença de PhoU, o Pi captado seria convertido em uma molécula sinalizadora, talvez atuando como substrato na síntese de ATP (STEED; WANNER, 1993).

2. Acúmulo de polifosfato: E. coli selvagem não exibe acúmulo considerável de poliP durante o crescimento em meio de cultivo complexo $(<1 \mathrm{nmol}$ de poliP $/ \mathrm{mg}$ de proteína). Por outro lado, P. aeruginosa e H. pylori podem acumular até 850 e $190 \mathrm{nmol}$ de poliP/mg proteína, respectivamente (KIM et al., 1998). Já quando phoU está ausente, ocorreria um defeito na sinalização, acarretando um superacúmulo de poliP na célula. Assim, o mutante phoU de E. coli acumula quantidades significativas de poliP no citoplasma sob condições de crescimento normal (400 nmol poliP/mg de proteína) (MOROHOSHI et al., 2002).

3. Resistência bacteriana: o mutante $\Delta p h o U$ apresenta caracteristicamente maior sensibilidade a diferentes tipos de antibióticos e estresses, como calor, estresse oxidativo, pH ácido, carência nutricional, etc., e também é deficiente no fenômeno de persistência bacteriana (LI; ZHANG, 2007).

Desta maneira, os diversos efeitos pleiotrópicos da mutação phoU sugerem um papel regulatório que vai muito além do metabolismo de Pi. 


\subsection{Pseudomonas aeruginosa e o metabolismo de $\mathrm{Pi}$}

Bactérias são organismos com uma surpreendente capacidade adaptativa diante de possíveis mudanças no seu microambiente. Esta habilidade é obtida através da correta adequação de seu metabolismo e fisiologia às novas condições do meio, logrando assim colonizar os mais variados ambientes naturais. Esta definição vale perfeitamente para descrever a espécie $P$. aeruginosa, que se encontra universalmente distribuída, em ambientes aquáticos e terrestres (GREEN et al., 1974; MONDS et al., 2006).

P. aeruginosa é um bacilo Gram-negativo do grupo das $\gamma$-Proteobacteria e de flagelo polar único. Diferentemente de outros membros do gênero Pseudomonas, a P. aeruginosa é uma espécie patogênica oportunista, sendo a maioria das infecções observadas em indivíduos imunocomprometidos, tais como pacientes com câncer (BENDIG et al., 1987), fibrose cística (FITZSIMMONS, 1993) e AIDS (ALI et al., 1995; KIELHOFNER et al., 1992). A infecção de queimaduras na pele também é frequente (CHURCH et al., 2006).

$P$. aeruginosa tem requerimentos nutricionais muito versáteis e tem a capacidade de crescer sob condições aeróbias e anaeróbias, usando $\mathrm{NO}_{3}$ ou arginina como aceptor final de elétrons da cadeia respiratória (REHM, 2008). A produção de vários pigmentos, envolvidos em diferentes processos celulares, é uma característica desta bactéria. Dentre esses, encontram-se: (i) pioverdina e piochelina, potentes agentes quelantes necessários à captação do ferro presente no ambiente; e (ii) piocianina, um fator de virulência de alta toxicidade que gera espécies reativas de oxigênio nas células do hospedeiro (MULLER, 2002).

O genoma da cepa PAO1 de P. aeruginosa, de 6,3 milhões de pares de bases, foi o primeiro genoma da espécie a ser sequenciado. Dos genes desta bactéria, 8,4\% estão provavelmente envolvidos em algum tipo de regulação, sendo essa uma proporção altíssima não encontrada ainda em nenhuma outra bactéria (STOVER et al., 2000). Tendo um extenso catálogo de genes envolvidos em regulação, transporte, catabolismo, quimiotaxia e efluxo de compostos orgânicos, $P$. aeruginosa torna-se uma bactéria profissional no que tange às estratégias de adaptação e sobrevivência (LEE et al., 2006).

Além de PAO1, os genomas da cepa PA14 e de outras nove cepas de P. aeruginosa também são conhecidos. O genoma de PA14 é ligeiramente maior que o de PAO1, tendo aproximadamente 6,5 milhões de pares de bases. Aproximadamente, 95,8\% do genoma de PAO1 está presente no genoma de PA14, e 91,7\% do genoma de PA14 corresponde 
ao genoma de PAO1. Dessa forma, PA14 apresenta genes adicionais, a maioria deles envolvidos em patogenicidade (LEE et al., 2006).

A resposta à limitação de $\mathrm{Pi}$ extracelular já foi descrita também em $P$. aeruginosa, apesar de não ter sido tão bem estudada como em E. coli. Em limitação de Pi, ocorre a síntese de vários tipos de proteínas, algumas relacionadas com o metabolismo do nutriente e, outras, com a virulência da bactéria. Por exemplo: (i) a fosfatase alcalina (FILLOUX et al., 1988); (ii) a fosfolipase C, um fator de virulência que contribui na formação de lesões da pele características da espécie (CHIN; WATTS, 1988; GRAY et al., 1982; KURIOKA; LIU, 1967; LIU, 1966; STINSON; HAYDEN, 1979); (iii) a proteína P, uma porina com alta especificidade por ânions, (HANCOCK et al., 1982); (iv) as proteínas PhoB/PhoR (ANBA et al., 1990; FILLOUX et al., 1988); e (v) PhoU e as proteínas do transportador Pst.

O operon pst de $P$. aeruginosa encontra-se aparentemente divido em duas partes: pstS e pstCAB-phoU (KATO et al., 1994; NIKATA et al., 1996; WU et al., 1999). Há um Pho box a montante do gene pstS (WU et al., 1999), e outro na região intergênica entre pstS e pstC (NIKATA et al., 1996) (Figura 5).

P. aeruginosa possui ao menos três proteínas envolvidas no metabolismo de poliP: PPK1, PPK2 e PPX. PPK1 é a proteína homóloga de PPK de E. coli, sendo a principal enzima envolvida na síntese do biopolímero em P. aeruginosa (ISHIGE et al., 1998; RASHID et al., 2000a). PPK1 sintetiza poliP na faixa de tamanho de 500-800 resíduos (ZHANG et al., 2002). PPK2 não está presente em E. coli, e difere de PPK1 principalmente em três aspectos: (i) além de ATP, pode utilizar GTP para a síntese de poliP (ISHIGE et al., 2002; ZHANG et al., 2002); (ii) sintetiza moléculas de 200-800 resíduos (ZHANG et al., 2002); (iii) in vitro, a taxa de síntese de GTP a partir de poliP é 75 vezes maior do que a taxa de síntese de poliP a partir de GTP. Desse modo, a função principal

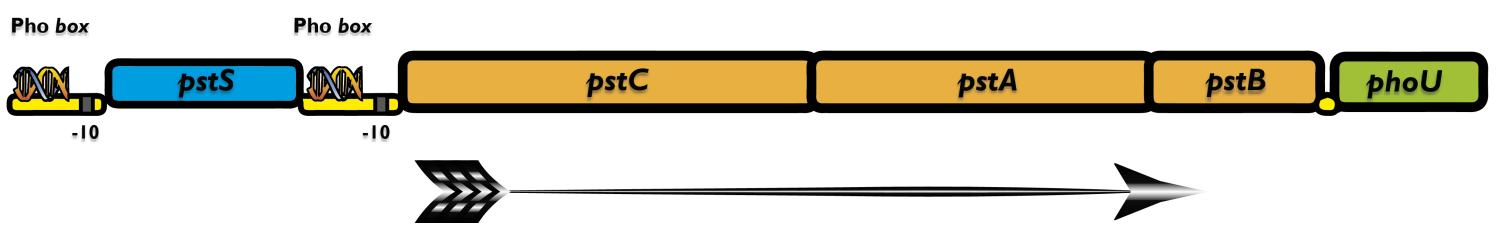

Figura 5-Organização dos genes do operon pst de $\boldsymbol{P}$. aeruginosa. As duas Pho box e as duas sequências -10 a montante de pstS e também de $p s t C$ são apresentadas. A seta indica a direção de transcrição do operon. 
de PPK2 parece ser a de sintetizar GTP a partir de poliP (ISHIGE et al., 2002; ZHANG et al., 2002). PPX de P. aeruginosa, a proteína homóloga de PPX de E. coli, é a principal enzima de degradação do poliP nessa bactéria (MIYAKE et al., 1999). No entanto, ela tem sido menos estudada do que as proteínas PPK1 e PPK2.

Ao contrário de E. coli, na qual os genes $p p k$ e $p p x$ formam um operon, em P. aeruginosa esses dois genes são adjacentes, porém, são transcritos em direções opostas (Figura 6) (ZAGO et al., 1999). A independência transcricional desses genes sugere que eles possam estar sendo regulados de forma antagônica, e poderia explicar por que P. aeruginosa, diferentemente de $E$. coli, acumula quantidades significativas de poliP, inclusive em condições normais de crescimento (KIM et al., 1998).

A regulação da expressão de $p p k$ e $p p x$ ainda é pouco entendida em $P$. aeruginosa e em outras bactérias. Recentemente, foi sugerido que a proteína PhoB atua na regulação de $p p x$ em PAO1, uma vez que ensaios com uma fusão transcricional entre o promotor de $p p x$ e o gene lac $Z$ da $\beta$-galactosidase mostraram que $p p x$ tem sua expressão aumentada em carência de Pi, de forma dependente de phoB (GALLARATO et al., 2014). Foi identificada também uma sequência Pho box putativa na região promotora de $p p x$. Até a presente data, a relação de $p p x$ com o regulon Pho não foi constatada em nenhuma outra espécie bacteriana.

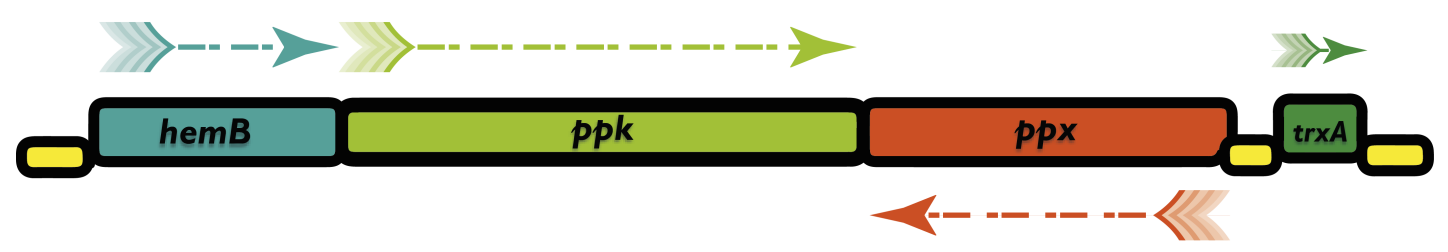

Figura 6 - Organização dos genes $p p k$ e $p p x$ no cromossomo de $P$. aeruginosa. As setas indicam a direção em que é transcrito cada gene. 


\section{OBJETIVOS}

\subsection{Objetivos gerais}

Considerando-se que $P$. aeruginosa acumula grandes quantidades de poliP, e que, tal como em E. coli, o nocaute de phoU exacerba ainda mais o acúmulo desse polímero, o objetivo deste trabalho foi investigar o metabolismo de poliP em P. aeruginosa PA14 e o papel de PhoU neste processo. Também visou-se analisar o operon pst desta bactéria em relação à sua expressão e regulação.

\subsection{Objetivos específicos}

- Caracterizar a região promotora do gene $p p k$.

- Estudar as condições necessárias à expressão dos genes $p p k$ e $p p x$.

- Medir os níveis de expressão dos genes ppk e ppx na cepa selvagem e no mutante phoU.

- Verificar se a proteína PhoB interage in vitro com a região promotora do gene $p p x$.

- Determinar o padrão de transcrição do operon pst.

- Avaliar uma possível atividade promotora a montante do gene phoU.

- Determinar a funcionalidade das duas sequências Pho box presentes no operon pst. 


\section{MATERIAIS E MÉTODOS}

\subsection{Cepas e plasmídios}

Cepas e plasmídios utilizados neste trabalho estão descritos na Tabela 1.

\subsection{Meios de cultura}

Culturas de P. aeruginosa foram cultivadas sob agitação a $37^{\circ} \mathrm{C}$ em LB ou em meio $\operatorname{DPMM}\left(0,5 \mathrm{mM}\right.$ de $\mathrm{MgSO}_{4}, 10 \mu \mathrm{M}$ de $\mathrm{FeSO}_{4}, 0,1 \mathrm{M}$ de HEPES, $7 \mathrm{mM}$ de $\left(\mathrm{NH}_{4}\right)_{2} \mathrm{SO}_{4}$, 20 mM de succinato de sódio, pH 7,4) (HANCOCK et al., 1981; HANCOCK et al., 1982). Uma solução de micronutrientes $\left(1,78 \mathrm{mM}\right.$ de $\mathrm{FeCl}_{3}, 1,62 \mathrm{mM}$ de $\mathrm{MnCl}_{2}, 2,45 \mathrm{mM}$ de $\mathrm{CaCl}_{2}, 13,91 \mathrm{mM}$ de $\mathrm{ZnCl}_{2}, 4,69 \mathrm{mM}$ de $\mathrm{H}_{3} \mathrm{BO}_{3}$ e $0,67 \mathrm{mM}$ de $\mathrm{CoSO}_{4}$ ), esterilizada com clorofórmio, foi acrescentada a esse meio a uma concentração final de 0,1\% (v/v). Quando acrescido com tampão fosfato $\left(\mathrm{H}_{2} \mathrm{PO}_{4}^{-} / \mathrm{HPO}_{4}^{2-}\right)$ a uma concentração final de $1 \mathrm{mM}$, o meio é considerado suficiente em $\mathrm{Pi}(+\mathrm{Pi})$ e, quando acrescido de $0,2 \mathrm{mM}$ dessa solução, é considerado deficiente em Pi (-Pi). O meio DPMM preparado com $\mathrm{NaNO}_{3}(20 \mathrm{mM})$ como fonte de nitrogênio e suficiente em Pi (+Pi) foi usado como meio de crescimento de culturas em condições de limitação de nitrogênio (-N).

Culturas de E. coli foram cultivadas sob agitação a $37{ }^{\circ} \mathrm{C}$ ou a $30{ }^{\circ} \mathrm{C}$ em meio LB. Quando necessário, no meio de cultura foram acrescentados antibióticos nas seguintes concentrações: $150 \mu \mathrm{g} / \mathrm{ml}$ de tetraciclina, $500 \mu \mathrm{g} / \mathrm{ml}$ de carbenicilina ou $100 \mu \mathrm{g} / \mathrm{ml}$ de gentamicina para $P$. aeruginosa, e $200 \mu \mathrm{g} / \mathrm{ml}$ de ampicilina, $15 \mu \mathrm{g} / \mathrm{ml}$ de tetraciclina, $30 \mu \mathrm{g} / \mathrm{ml}$ de ácido nalidíxico ou $50 \mu \mathrm{g} / \mathrm{ml}$ de canamicina para E. coli.

\subsection{Construção de fusões transcricionais com o gene lacZ}

\subsubsection{Amplificação das regiões promotoras}

As diferentes regiões promotoras no genoma de PA14 foram obtidas na base de dados www.pseudomonas.com. O programa Primer-BLAST (YE et al., 2012) foi utilizado no desenho dos oligonucleotídeos. As sequências e características de cada oligonucleotídeo estão descritas na Tabela 2.

Cada região promotora foi amplificada por PCR utilizando-se o kit GoTaq ${ }^{\circledR}$ Green Master Mix 2X (Promega). Como DNA molde foi utilizada uma colônia fresca de PA14. Com o mix foi empregado um programa térmico $\left(2\right.$ min a $94{ }^{\circ} \mathrm{C}$ e 25 ciclos de 30 s a $94{ }^{\circ} \mathrm{C}$, 
Tabela 1 - Cepas e plasmídios utilizados neste trabalho

\begin{tabular}{|c|c|c|}
\hline Cepa ou plasmídio & Descrição & Referência ou fonte \\
\hline E. coli & & \\
\hline DH10B & $\begin{array}{l}\mathrm{F}^{-} \lambda^{-} \text {endA1 } 1 \text { glnV44 thi-1 recA1 relA1 gyrA96 deoR nupG } \\
\phi 80 \mathrm{~d} l a c Z \Delta \mathrm{M} 15 \quad \Delta(\text { lacZYA } \\
\text { mcrA merBCmrr gale }\end{array}$ & (DURFEE et al., 2008) \\
\hline MG1655 & $\mathrm{F}^{-} \lambda^{-} \mathrm{i} l v G^{-} r f b-50 r p h-1$ & (BLATTNER et al., 1997) \\
\hline S17-1 & $\begin{array}{l}\text { Ec294:: }[\mathrm{RP} 4-2(\mathrm{Tc}:: \mathrm{Mu})(K m:: \operatorname{Tn} 7)] \mathrm{Tp}^{\mathrm{r}}, \mathrm{Sm}^{\mathrm{r}}, \mathrm{tra}^{+} \text {recA, pro, } \\
\text { res }^{-}\end{array}$ & (SIMON et al., 1983) \\
\hline BL21 (DE3) & B F- dcm ompT $h s d S\left(\mathrm{r}_{B}{ }^{-} \mathrm{m}_{B}{ }^{-}\right)$gal $\lambda(\mathrm{DE} 3)$ & (STUDIER; MOFFATT, 1986) \\
\hline $\begin{array}{l}\text { P. aeruginosa } \\
\text { UCBPP-PA14 }\end{array}$ & Cepa selvagem & (RAHME et al., 1995) \\
\hline CB-S7Z & PA14 attB::lacZ & Este trabalho \\
\hline CB-SBK & PA14 attB::(hemB-ppk) $P-l a c Z$ & Este trabalho \\
\hline CB-S7K & PA14 attB: $:_{p p k} P-l a c Z$ & Este trabalho \\
\hline CB-S7X & PA14 attB::ppx P-lacZ & Este trabalho \\
\hline CB-S7U & PA14 attB: ${ }_{p h o U} P-l a c Z$ & Este trabalho \\
\hline LG01 & PA14 phoU::pKNOCK-Gm & (ALMEIDA, 2013) \\
\hline CB-M7Z & PA14 phoU::pKNOCK-Gm attB::lacZ & Este trabalho \\
\hline CB-MBK & PA14 phoU::pKNOCK-Gm attB::(hemB-ppk) $P$-lac $Z$ & Este trabalho \\
\hline CB-M7X & PA14 phoU::pKNOCK-Gm attB::ppx P-lacZ & Este trabalho \\
\hline $\begin{array}{l}\text { Plasmídios } \\
\text { pGEM }^{\circledR}-\mathrm{T} \text { Easy }\end{array}$ & Amp $^{\mathrm{r}}$ ColE1; vetor de clonagem. & Promega \\
\hline $\mathrm{pTZ} 57 \mathrm{R} / \mathrm{T}$ & $\mathrm{Amp}^{\mathrm{r}}$; vetor de clonagem. & Thermo Scientific \\
\hline Mini-CTX-lacZ & $\begin{array}{l}\text { Tet }^{\mathrm{r}} \text { oriT } \\
\text { cricionais } \text { com lactor integrativo para a construção de fusões trans- } \\
\text { cromossomo de } P \text {. aeruginosa }\end{array}$ & (BECHER; SCHWEIZER, 2000) \\
\hline pFLP2 & $\begin{array}{l}\text { Amp }^{\mathrm{r}} / \mathrm{Car}^{\mathrm{r}} \text {; plasmídio que contém o gene que codifica a recombi- } \\
\text { nase Flp }\end{array}$ & (HOANG et al., 1998) \\
\hline pGEM-K & Promotor de $p p k$ de PA14 clonado no vetor pGEM ${ }^{\circledR}-\mathrm{T}$ Easy & Este trabalho \\
\hline pGEM-X & Promotor de $p p x$ de PA14 clonado no vetor pGEM ${ }^{\circledR}$-T Easy & Este trabalho \\
\hline pTZ-BK & $\begin{array}{l}\text { Região de PA14 de } 2.075 \mathrm{pb} \text { que contém o gene hemB, seu pro- } \\
\text { motor e a região promotora de } p p k \text {, clonada no vetor } \mathrm{pTZ} 57 \mathrm{R} / \mathrm{T}\end{array}$ & Este trabalho \\
\hline pTZ-U & $\begin{array}{l}\text { Região imediatamente a montante de } p h o U \text { de PA14 clonada no } \\
\text { vetor pTZ57R/T }\end{array}$ & Este trabalho \\
\hline pPVSM-K & Promotor de $p p k$ de PA14 clonado no vetor Mini-CTX-lacZ & Este trabalho \\
\hline pPVSM-BK & $\begin{array}{l}\text { Região de PA14 de } 2.075 \text { pb que contém o gene hemB, seu promo- } \\
\text { tor e a região promotora de } p p k \text {, clonada no vetor Mini-CTX-lacZ }\end{array}$ & Este trabalho \\
\hline pPVSM-X & Promotor de $p p x$ de PA14 clonado no vetor Mini-CTX-lacZ & Este trabalho \\
\hline pPVSM-U & $\begin{array}{l}\text { Região imediatamente a montante de } p h o U \text { de PA14 clonada no } \\
\text { vetor Mini-CTX-lacZ }\end{array}$ & Este trabalho \\
\hline pGEM-B & phoB de PA14 clonado no vetor pGEM ${ }^{\circledR}$-T Easy & Este trabalho \\
\hline pET-28a $(+)$ & $\operatorname{Kan}^{\mathrm{r}}$; vetor de expressão que possui o promotor T7lac & Novagen \\
\hline pET-phoB-his $(6 x)$ & phoB de PA14 clonado no vetor pET-28a(+) & Este trabalho \\
\hline
\end{tabular}


30 s com uma temperatura de anelamento variável (ver Tabela 2) e uma extensão a $74{ }^{\circ} \mathrm{C}$ com tempos diferentes, de acordo com o tamanho do amplicon) em um termociclador Mastercycler ${ }^{\circledR}$ personal (Eppendorf).

Após serem observados em um mini gel de agarose 1\%, os produtos de PCR foram purificados com o kit Wizard ${ }^{(B)}$ Gel and PCR Clean-Up System (Promega) conforme as recomendações do fabricante, e quantificados no espectrofotômetro Epoch ${ }^{\mathrm{TM}}$ (BioTek).

\subsubsection{Clonagem dos promotores nos vetores pTZ57R/T e pGEM ${ }^{\circledR}-\mathrm{T}$ Easy}

Os fragmentos amplificados por PCR, ${ }_{(h e m B-p p k)} P$ e ${ }_{p h o U} P$, foram clonados no vetor pTZ57R/T utilizando-se o kit InsTAclone PCR Cloning (Thermo Scientific). O mix de ligação foi preparado em um volume final de $30 \mu \mathrm{l}$, contendo: $1 \mu \mathrm{l}$ de pTZ57R/T (55 ng), $3 \mu \mathrm{l}$ de tampão 10X, $22 \mu \mathrm{l}$ de $\mathrm{dH}_{2} \mathrm{O}, 1 \mu \mathrm{l}$ de T4 DNA ligase e $3 \mu \mathrm{l}$ do respectivo produto de PCR ( $\approx 170 \mathrm{ng})$. Os fragmentos ${ }_{p p k} P \mathrm{e}_{p p x} P$ foram clonados no vetor $\mathrm{pGEM}^{\circledR}-\mathrm{T}$ Easy. O mix dessa ligação foi feito em um volume total de $10 \mu$ l, contendo: $1 \mu$ de vetor $(50 \mathrm{ng})$,

Tabela 2 - Oligonucleotídeos utilizados neste trabalho

\begin{tabular}{|c|c|c|c|c|}
\hline Alvo/finalidade & Oligonucleotídeo & Sequência & $\begin{array}{c}\text { Temperatura } \\
\text { hibridização }\left({ }^{\circ} \mathrm{C}\right)\end{array}$ & $\begin{array}{c}\text { Tamanho } \\
\text { amplicon (pb) }\end{array}$ \\
\hline \multirow[t]{2}{*}{${ }_{p p k} P /$ fusão transcricional } & PA14-ppk(p)-F & (KpnI) 5'-ATCCGGTACCGCCTTCAAAC-3' & 51 & 368 \\
\hline & $\mathrm{PA} 14-p p k(p)-\mathrm{R}$ & 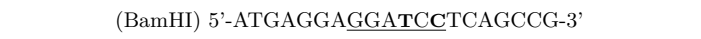 & & \\
\hline \multirow[t]{2}{*}{$($ hem $B-p p k) P /$ fusão transcricional } & $\mathrm{PA} 14-h e m B(p g)-p p k(p)-\mathrm{F}$ & 5'-TGTCTTGAAACGCCGCCATA-3' & 50 & 2.075 \\
\hline & $\mathrm{PA} 14-h e m B(p g)-p p k(p)-\mathrm{R}$ & 5'-GAGGAACTTCAGCCGCTCCA-3' & & \\
\hline \multirow[t]{2}{*}{${ }_{p p x} P /$ fusão transcricional } & $\operatorname{PA} 14-\operatorname{tr} x A(g)-p p x(p)-\mathrm{F}$ & (KpnI) 5'-ACGTCGGGTACCCGAATTTA-3' & 50 & 801 \\
\hline & PA14- $\operatorname{tr} x A(g)-p p x(p)-\mathrm{R}$ & (BamHI) 5'-CTGAGATTGGGATCCTCGTC-3' & & \\
\hline \multirow[t]{2}{*}{${ }_{p h o U} P /$ fusão transcricional } & $P A-p s t B 4445 F$ & 5'-GATGAACATTCCGAAGCAG-3' & 49 & 1.334 \\
\hline & PA-phoU5778R & 5'-GGGTCTTCCATCATGTAGGT-3' & & \\
\hline \multirow[t]{2}{*}{ Região interna hemB/RT-PCR } & PA14-hemB $(g)$-F & 5'-TCCTCAACGACGTCAGCATC-3' & 55 & 391 \\
\hline & PA14-hemB $(g)$-R & 5'-GCGCGGAATTCATCCTTCAC-3' & & \\
\hline \multirow[t]{2}{*}{ Região interna $p p k / \mathrm{RT}-\mathrm{PCR}$} & $\mathrm{PA} 14-p p k(g)-\mathrm{F}$ & 5'-AGAAGCAGATCACCTTCGCC-3' & 55 & 299 \\
\hline & PA14- $p p k(g)-\mathrm{R}$ & 5'-GAGGCTCTTGTTCACCAGCA-3' & & \\
\hline \multirow[t]{2}{*}{ Final de hemB e início de $p p k /$ RT-PCR } & PA14-hemB $(g)$-F & descrita acima & 55 & 1.198 \\
\hline & $\mathrm{PA} 14-p p k(g)-\mathrm{R}$ & descrita acima & & \\
\hline \multirow[t]{2}{*}{ Região interna $p s t S /$ northern blot } & pstS384F & 5'-GAGTACAAGCGCCTCTATCC-3' & 50 & 519 \\
\hline & pstS902R & 5'-CTTGTAGCCGATACCGGAG-3' & & \\
\hline \multirow[t]{2}{*}{ Região interna $p s t C /$ northern blot } & pst $C 1053 \mathrm{~F}$ & 5'-GTGAAAGCCATCTACCTCGAC-3' & 57 & 760 \\
\hline & pstC $1812 \mathrm{R}$ & 5'-CCTCCATCAGCTCGATCAC-3' & & \\
\hline \multirow[t]{2}{*}{ Região interna phoU/northern blot } & phoU $5398 \mathrm{~F}$ & 5'-CGACGACCAGATCAACCAG-3' & 50 & 381 \\
\hline & phoU5778R & 5'-GGGTCTTCCATCATGTAGGT-3' & & \\
\hline \multirow[t]{2}{*}{${ }_{p s t S} P /$ gel shift } & PA14-pstS(EMSA)-F & 5'-GGCTTGCGGAAAAATGTCGG-3' & 45 & 124 \\
\hline & PA14-pstS(EMSA)-R & 5'-TCCTTGGACAGGATGGGGTT-3' & & \\
\hline \multirow[t]{2}{*}{${ }_{p s t C} P /$ gel shift } & PA14-pst $C$ (EMSA)-F & 5'-GTCCAGGCATGAAGGCTCT-3' & 48 & 176 \\
\hline & PA14-pstC(EMSA)-R & 5'-GCAAGGGAGGAGTTCATCGG-3' & & \\
\hline \multirow[t]{2}{*}{${ }_{\text {ppx }} P /$ gel shift } & PA14- $p p x($ EMSA)-F & 5'-GTCTCTATCGTTGGTCGGC-3' & 45 & 119 \\
\hline & PA14- $p p x($ EMSA)-R & 5'-AGGTTTTTGCGGCATGCTT-3' & & \\
\hline \multirow[t]{2}{*}{ phoB/gel shift } & $p h o B(g)-\mathrm{F}$ & (NdeI) 5'-CGAGTTACCATATGGTTGGCAAGACAATCCTCATC-3' & 50 e 58 & 710 \\
\hline & $\operatorname{phoB}(g)-\mathrm{R}$ & (HindIII) 5'-CGTAAGCTTTCAGCTCTTGGTGGAGAAACGAT-3' & & \\
\hline
\end{tabular}

As sequências sublinhadas mostram o sítio de restrição da enzima anotada. Letras de menor tamanho indicam a presença de mismatches, introduzidos para formar o sítio de restrição desejado. Em negrito aparecem indicados os códons de iniciação e parada de $p h o B$. 
$5 \mu \mathrm{l}$ de Rapid Ligation buffer $2 \mathrm{X}, 1 \mu \mathrm{l}$ de T4 DNA ligase e $3 \mu \mathrm{l}$ do respectivo produto de $\operatorname{PCR}(\approx 170 \mathrm{ng})$.

Cada reação de ligação foi incubada overnight a $4{ }^{\circ} \mathrm{C}$. No dia seguinte, $2 \mu \mathrm{l}$ do produto de cada ligação foram utilizados para eletroporar $50 \mu \mathrm{l}$ de E. coli DH10B eletrocompetente. As células foram plaqueadas e incubadas overnight a $37{ }^{\circ} \mathrm{C}$ em placas de L-ágar suplementadas com ampicilina, $80 \mu \mathrm{g} / \mathrm{ml}$ de X-gal (Thermo Scientific) e $0.5 \mathrm{mM}$ de IPTG (Bio Basic Inc) para a seleção de colônias por $\alpha$-complementação.

Colônias brancas foram isoladas e cultivadas overnight em meio LB. Os plasmídios foram extraídos pelo método de lise alcalina (SAMBROOK; RUSSELL, 2001), digeridos com enzimas de restrição e analisados em gel de agarose.

Os plasmídios derivados de pGEM ${ }^{\circledR}-\mathrm{T}$ Easy foram digeridos com EcoRI, enquanto que os derivados de pTZ57R/T foram digeridos com KpnI e BamHI. Para determinar a orientação de clonagem dos fragmentos ${ }_{(h e m B-p p k)} P$ e ${ }_{p h o U} P$, clonados em pTZ57R/T, foi aproveitada a presença de um sítio de restrição XhoI interno próximo da extremidade 3' da sequência de ${ }_{p h o U} P$ e um sítio BamHI interno próximo da extremidade 3' do fragmento $($ hemB-ppk) $P$.

\subsubsection{Subclonagem dos promotores no vetor Mini-CTX-lacZ}

Os plasmídios recombinantes pTZ-U (promotor de phoU), pGEM-K (promotor de $p p k$ ), pGEM-X (promotor de $p p x$ ) e o vetor Mini-CTX-lacZ foram digeridos com KpnI (Thermo Scientific) e BamHI (Thermo Scientific). Já o plasmídio pTZ-BK (promotor de hemB) e o vetor Mini-CTX-lacZ foram digeridos com KpnI (Thermo Scientific) e HindIII (Thermo Scientific). Após a digestão, os fragmentos de DNA relevantes foram separados em gel de agarose e purificados utilizando-se o kit Wizard $^{\circledR} S V$ Gel and PCR Clean-Up System (Promega).

Os fragmentos de DNA foram ligados ao vetor Mini-CTX-lacZ utilizando-se a a proporção 1:3 (vetor:inserto). As reações foram incubadas a $16{ }^{\circ} \mathrm{C}$ overnight. A enzima foi então inativada a $70{ }^{\circ} \mathrm{C}$ por 5 min e $1 \mu$ de cada ligação foi eletroporado na cepa DH10B. Colônias azuis foram repicadas e cultivadas em meio LB suplementado com tetraciclina para a extração dos plasmídios. A presença dos insertos foi determinada através de uma análise de restrição com as enzimas respectivas empregadas nas reações de digestão prévias ao processo de clonagem. Os plasmídios resultantes foram denominados: pPVSM-K, pPVSM-BK, pPVSM-X e pPVSM-U. 


\subsection{Sequenciamento}

Todos os plasmídios foram sequenciados utilizando-se o kit BigDye terminator version

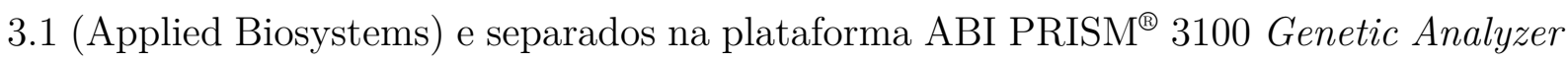
(HITACHI) para sequenciamento por eletroforese capilar.

\subsection{Integração cromossomal das fusões transcricionais construídas com o ve- tor Mini-CTX-lacZ, no cromossomo de PA14 e do mutante phoU}

Para inserir as fusões em P. aeruginosa, primeiro, a cepa S17-1, que carrega no cromossomo os genes do sistema RP4 de conjugação, foi eletrotransformada com as fusões Mini-CTX-lacZ. Em seguida, os transformantes contendo as fusões foram utilizados como doadores em um processo de conjugação para a cepa PA14.

O Mini-CTX-lacZ é inserido no sítio attB do cromossomo da bactéria por recombinação sítio específica. Essa recombinação é mediada pela proteína integrase codificada pelo próprio vetor (Figura 7). Uma vez inserida a fusão no cromossomo da bactéria, esta é transformada com o vetor pFLP2, que codifica a recombinase Flp. Essa proteína catalisa a excisão da maioria dos genes do vetor, permanecendo no cromossomo de $P$. aeruginosa apenas uma cópia da fusão promotor-lacZ junto com a "cicatriz" da recombinação.

\subsection{Eletrotransformação de $E$. coli e P. aeruginosa}

Para a eletrotransformação de E. coli, bactérias cultivadas overnight a $37{ }^{\circ} \mathrm{C} \mathrm{em}$ $2 \mathrm{ml}$ de meio LB foram centrifugadas à velocidade máxima por 1 minuto. Cada pellet foi ressuspendido em $2 \mathrm{ml}$ de água destilada gelada estéril e recentrifugado. A mesma lavagem foi repetida mais duas vezes utilizando-se $1 \mathrm{ml}$ de água e $500 \mu \mathrm{l}$ de uma solução gelada de glicerol $10 \%$ estéril. Finalmente, cada pellet foi ressuspendido em um volume de $50 \mu \mathrm{l}$ da solução de glicerol $10 \%$ gelada. Após aplicar um pulso $(25 \mu \mathrm{F}, 200 \Omega$ e $2,5 \mathrm{kV}$, no eletroporador MicroPulser ${ }^{\mathrm{TM}}$ (Bio-Rad)) foram acrescentados $950 \mu \mathrm{l}$ de meio LB. A seguir, as bactérias foram transferidas para um tubo de ensaio estéril. Após serem incubadas a $37^{\circ} \mathrm{C}$ por 90 min com LB, as bactérias foram plaqueadas e incubadas a $37^{\circ} \mathrm{C}$ overnight em L-ágar suplementado com o antibiótico apropriado.

Na eletroporação de PA14, empregou-se a metodologia descrita em (CHOI et al., 2006). Brevemente, bactérias cultivadas em $6 \mathrm{ml}$ de LB a $37^{\circ} \mathrm{C}$ overnight foram centrifugadas a $8.000 \mathrm{rpm}$ por $5 \mathrm{~min}$. Cada pellet foi ressuspendido em $10 \mathrm{ml}$ de uma solução 

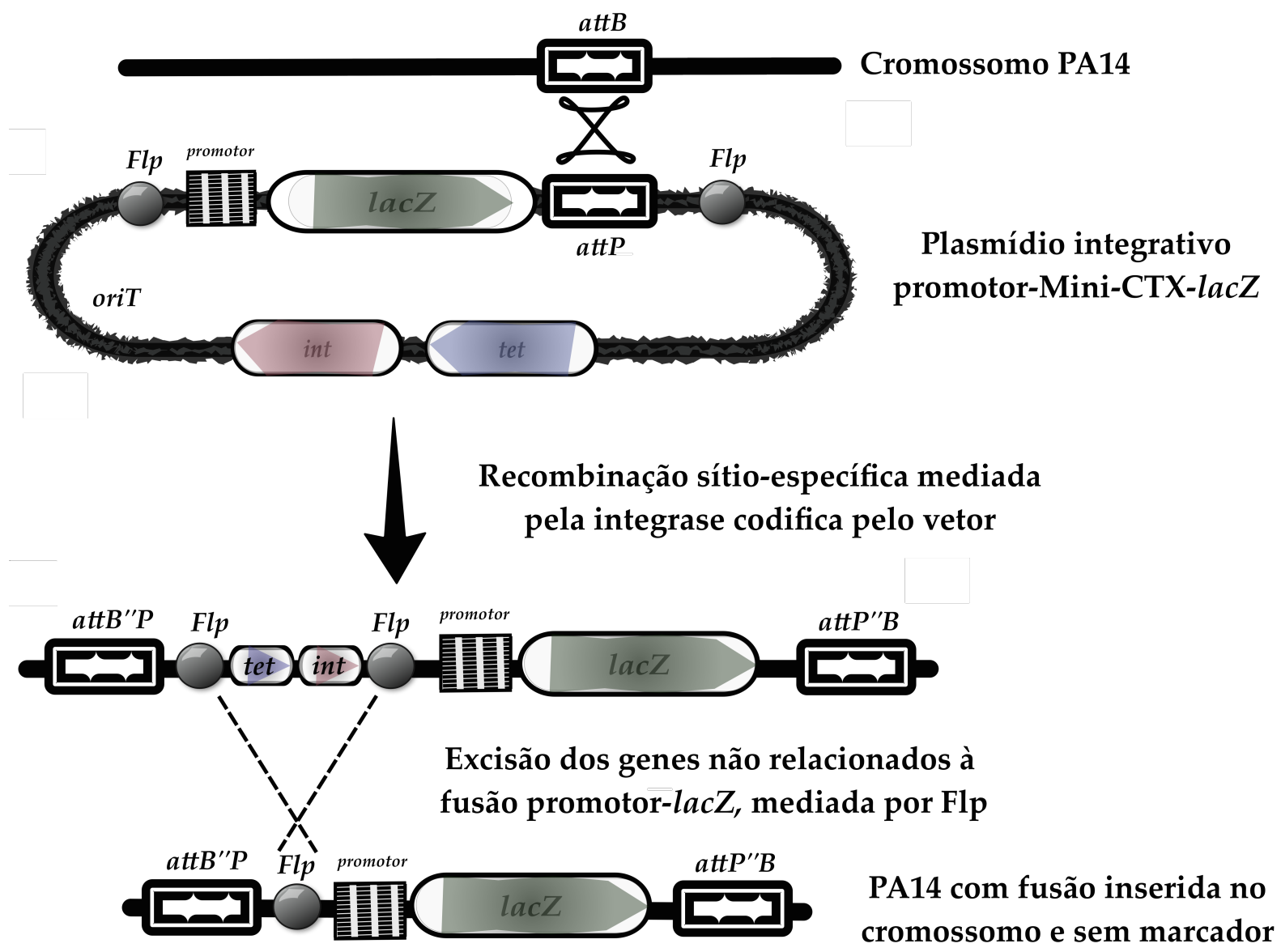

Figura 7 - Mecanismo gênico da integração e excisão do backbone do plasmídio não replicativo promotor-Mini-CTX-lacZ em PA14 e o mutante phoU. O sítio attP, presente no plasmídio contendo o promotor clonado, integra-se no cromossomo de PA14 pelo sítio attB por meio da atividade da integrase codificada pelo próprio vetor. Bactérias transformadas são então selecionadas em meio seletivo contendo tetraciclina. Finalmente, a proteína Flp, codificada pelo vetor pFLP2, excisa genes e promotores do plasmídio integrado que, potencialmente, possam interferir na expressão da fusão transcricional. Adaptado de (BECHER; SCHWEIZER, 2000).

estéril de sacarose $300 \mathrm{mM}$ a temperatura ambiente. As culturas foram então centrifugadas por 5 min à velocidade máxima e cada pellet foi ressuspendido novamente em $10 \mathrm{ml}$ da solução de sacarose. A lavagem anterior foi repetida duas vezes. Por fim, os pellets foram ressuspendidos em $100 \mu \mathrm{l}$ da solução de sacarose. Após aplicado o pulso $(1,8 \mathrm{kV})$ em $80 \mu \mathrm{l}$ de cultura eletrocompetente, foram acrescentados $920 \mu \mathrm{l}$ de LB. As bactérias eletroporadas foram incubadas a $37^{\circ} \mathrm{C}$ por 2 horas e plaqueadas em L-ágar suplementado com antibiótico. 


\subsection{Conjugação}

A mobilização das fusões transcricionais em PA14 e no mutante $p h o U$ foi feita via conjugação utilizando-se a cepa de E. coli S17-1 como doadora. PA14 e S17-1, portadora de cada fusão, foram cultivadas em meio LB a $37{ }^{\circ} \mathrm{C}$ overnight. A seguir, foram feitas subculturas em LB. Cada subcultura foi cultivada até uma $\mathrm{DO}_{600}$ de aproximadamente 0,4. Nesse momento, 0,5 ml de cada $\mathrm{S} 17-1$ foram misturados com 0,5 ml de PA14. Os pares conjugantes foram incubados a $37^{\circ} \mathrm{C}$ por um período de 4 a 5 horas sob agitação de 150 rpm. No final, eles foram plaqueados em L-ágar suplementado com ácido nalidíxico e tetraciclina, e incubados a $37^{\circ} \mathrm{C}$ por aproximadamente 48 horas. Colônias exconjugantes foram repicadas em placas da mesma composição.

\subsection{Excisão dos genes do backbone do Mini-CTX-lacZ do cromossomo de PA14 e do mutante phoU}

Os exconjugantes foram eletrotransformados com o vetor pFLP2. Os transformantes foram selecionados em placas de L-ágar suplementado com carbenicilina. Bactérias Tet $^{\mathrm{s}}$ Car $^{\mathrm{r}}$ foram então curadas do plasmídio pFLP2 repicando as bactérias em placas de L-ágar/sacarose 5\%. o pFLP2 carrega o gene sacB de Bacillus subtilis que codifica a enzima levansacarose que, na presença de sacarose, gera o acúmulo tóxico de levana, um biopolímero de frutose, no periplasma de bactérias Gram-negativas, inibindo seu crescimento (GAY et al., 1985). Portanto, só bactérias que perderam o plasmídio, ou cujo gene $s a c B$ foi inativado, conseguirão crescer em meio ágar com sacarose (Figura 8).

As cepas resultantes, descritas na Tabela 1, foram avaliadas para confirmar o excisado do backbone do vetor Mini-CTX-lacZ, a perda do vetor pFLP2 e atividade basal da $\beta$-galactosidase, por repique em placas de L-ágar suplementado com tetraciclina, carbenicilina ou X-gal. Com as cepas do mutante phoU, além dos testes descritos acima, foi feito um plaqueamento adicional para confirmar sua Pho constitutividade em L-ágar suplementado com $40 \mu \mathrm{g} / \mathrm{ml}$ de XP (Thermo Scientific). 


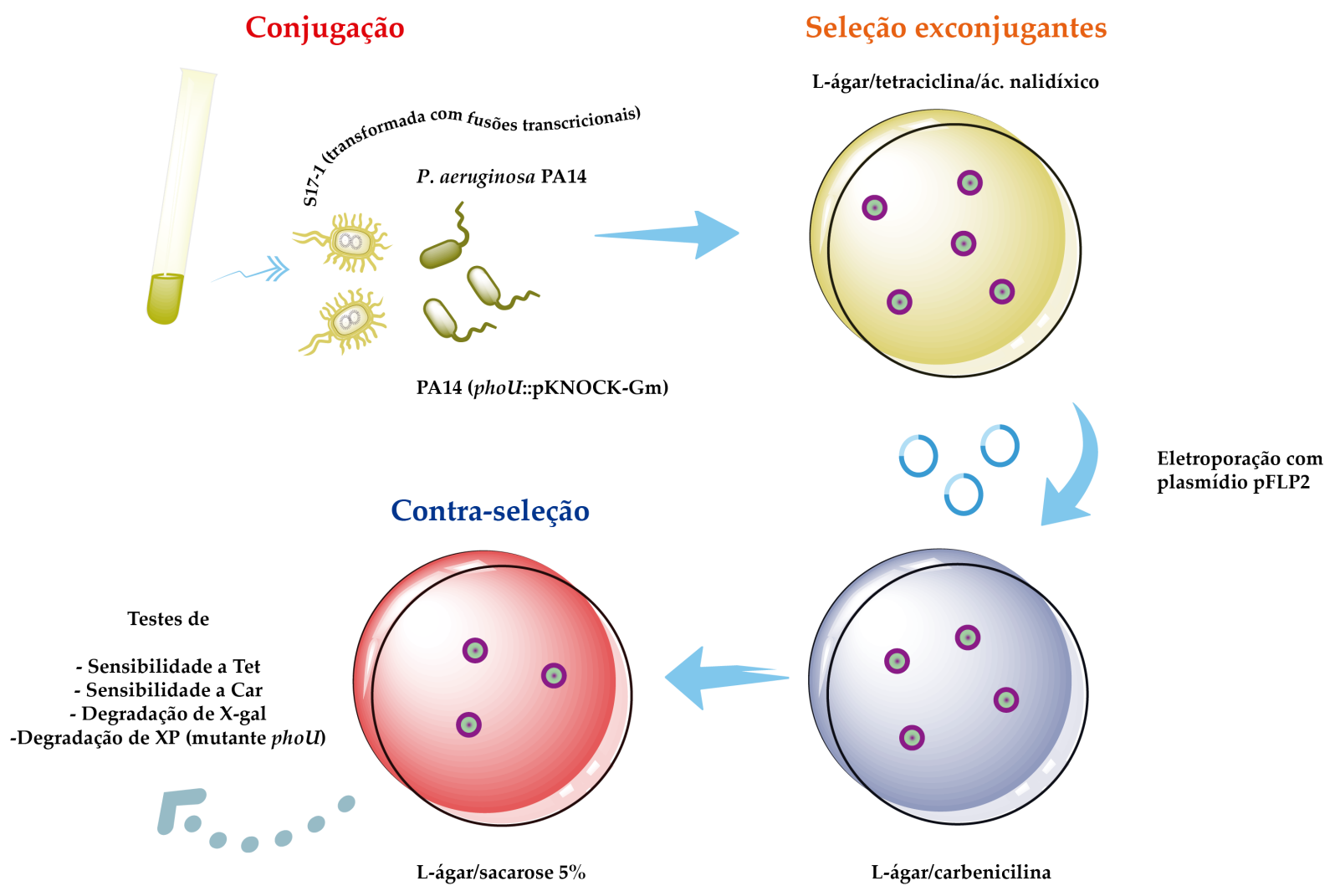

Figura 8 - Metodologia aplicada na construção de cepas de PA14 carregando fusões transcricionais de cópia única no cromossomo. Bactérias de S17-1 carregando o plasmídio promotor-Mini-CTX-lacZ foram conjugadas com PA14. Exconjugantes de PA14 foram selecionados em placas de meio seletivo contendo tetraciclina e ácido nalidíxico. A seguir, as bactérias $\operatorname{Tet}^{\mathrm{r}}$ foram eletroporadas com o vetor pFLP2, e os transformantes foram selecionados em placa contendo carbenicilina. Finalmente, bactérias $\mathrm{Tet}^{\mathrm{s}} \mathrm{Car}^{\mathrm{r}}$ foram contraselecionadas em meio L-ágar suplementado com sacarose 5\%. Algumas colônias da placa com sacarose $5 \%$ foram repicadas em placas com antibiótico, X-gal e XP para confirmar a excisão do backbone do vetor, a cura do plasmídio pFLP2 e a atividade basal da $\beta$-galactosidase, e, no caso do mutante pho $U$, a atividade da FA.

\subsection{Avaliação da faixa de linearidade do espectrofotômetro de microplacas $\operatorname{Epoch}^{\mathrm{TM}}$}

Foram preparadas diluições seriadas de o-nitrofenol (ONP) nas faixas de absorbâncias de 0 a 3 . O mesmo foi feito para uma cultura de PA14 cultivada em meio LB overnight a $37^{\circ} \mathrm{C}$. A seguir, foram transferidos em duplicata $200 \mu \mathrm{l}$ de cada amostra a uma microplaca de 96 poços e foi determinada a $\mathrm{DO}_{420}$ das diluições de $\mathrm{ONP}$ e a $\mathrm{DO}_{600}$ das diluições das culturas. As leituras de absorbância foram feitas e reportadas utilizando-se a opção de correção automática do caminho óptico do espectrofotômetro de placas. 


\subsection{Ensaios de $\beta$-galactosidase em microplaca de 96 poços}

Os ensaios de $\beta$-galactosidase em placa de 96 poços foram baseados nas metodologias descritas em (GRIFFITH; WOLF JR., 2002; ZHANG; BREMER, 1995). Brevemente, colônias de cada cepa a ser avaliada foram inoculadas em poços contendo meio DPMM $(+\mathrm{Pi},-\mathrm{Pi}$ ou $-\mathrm{N})$ de uma microplaca estéril de 24 poços. Alguns poços com meio não inoculado foram usados como controle negativo. A microplaca com os inóculos foi tampada e selada com fita. As culturas foram cultivadas a $37^{\circ} \mathrm{C}$ a $160 \mathrm{rpm}$ por pelo menos 17 horas. $\mathrm{A} \mathrm{DO}_{600}$ de cada cultura foi determinada. Em seguida, as culturas foram diluídas a uma $\mathrm{DO}_{600}$ de aproximadamente 0,050 no meio de cultura respectivo em uma nova microplaca estéril de 24 poços. As subculturas foram cultivadas a $37^{\circ} \mathrm{C}$ a $150 \mathrm{rpm}$ por tempos variáveis, entre 8 e 24 horas.

Alíquotas de cada cultura foram coletadas em diferentes momentos do crescimento para ensaios de $\beta$-galactosidase. Primeiro, foi determinada a $\mathrm{DO}_{600}$ e, em seguida, alíquotas de $20 \mu \mathrm{l}$ de cada cultura foram transferidas para uma microplaca de 96 poços contendo $80 \mu \mathrm{l} /$ poço da solução de permeabilização recém preparada (100 mM de $\mathrm{Na}_{2} \mathrm{HPO}_{4}, 20 \mathrm{mM}$ de $\mathrm{KCl}, 2 \mathrm{mM}$ de $\mathrm{MgSO}_{4}$, 0,6 mg/ml de CTAB, 0,4 mg/ml de deoxicolato de sódio, 2,7 mM de TCEP e carbenicilina). A microplaca contendo as células permeabilizadas foi tampada e mantida a $4{ }^{\circ} \mathrm{C}$ até sua utilização.

Após serem permeabilizadas todas as amostras, foram transferidos $25 \mu \mathrm{l}$ de cada cultura permeabilizada a uma nova microplaca de 96 poços. O ensaio foi iniciado pela adição de $175 \mu \mathrm{l}$ de uma solução de substrato recém preparada $\left(60 \mathrm{mM}\right.$ de $\mathrm{Na}_{2} \mathrm{HPO}_{4}, 40 \mathrm{mM}$ de $\mathrm{NaH}_{2} \mathrm{PO}_{4}, 4 \mathrm{mg} / \mathrm{ml}$ de $\mathrm{ONPG}$ e $1,35 \mathrm{mM}$ de TCEP) às células permeabilizadas. A microplaca foi protegida da luz e centrifugada por 5 min a $1.400 \mathrm{rpm}$ para eliminar possíveis interferências nas leituras espectrofotométricas devido à formação de bolhas em cada poço como consequência da pipetagem. A placa foi introduzida no leitor de microplacas, foi determinada a $\mathrm{DO}_{550}$ e a reação foi monitorada a uma $\mathrm{DO}_{420}$ a cada 15 min por 14 horas a temperatura ambiente. Cada experimento foi realizado em triplicata técnica e em pelo menos triplicata biológica. As unidades de $\beta$-galactosidase foram calculadas empregando-se a equação 4.1 como descrito em (MILLER, 1992).

$$
\text { Unidades de } \beta \text {-galactosidase }=\frac{1000 \times \mathrm{DO}_{420}-\left(1,75 \times \mathrm{DO}_{550}\right)}{t \times v \times \mathrm{DO}_{600}}
$$


Onde:

$\mathrm{DO}_{420}=$ absorbância da amostra, a $420 \mathrm{~nm}$.

$\mathrm{DO}_{550}=$ absorbância a $550 \mathrm{~nm}$. Quando multiplicada por 1,75 permite determinar a contribuição dos restos bacterianos à absorbância a $420 \mathrm{~nm}$.

$t=$ tempo de reação, em min.

$v=$ volume de células utilizadas no ensaio, em $\mathrm{ml}$.

$\mathrm{DO}_{600}=$ concentração celular a $600 \mathrm{~nm}$.

\subsection{Ensaio de fosfatase alcalina}

Os ensaios foram efetuados como descrito em (SPIRA et al., 1995). Utilizou-se pNPP (Amresco) como substrato da enzima, a uma concentração de $1 \mathrm{mg} / \mathrm{ml}$ em tampão tris·HCl $1 \mathrm{M}(\mathrm{pH} 8,0)$. Na parte final de cada ensaio, as amostras foram centrifugadas por 5 min a $10.000 \mathrm{rpm}$ antes da leitura espectrofotométrica a $410 \mathrm{~nm}$. A atividade da enzima foi calculada com base na equação 4.2.

$$
\text { Unidades de fosfatase alcalina }=\frac{\mathrm{A}_{410} \times \mathrm{fd}}{t \times \mathrm{DO}_{600}}
$$

Onde:

$\mathrm{A}_{410}=$ absorbância da amostra, a $410 \mathrm{~nm}$.

$t=$ tempo de reação, em min.

$\mathrm{fd}=$ fator de diluição das células testadas.

$\mathrm{DO}_{600}=$ concentração celular a $600 \mathrm{~nm}$.

\subsection{Extração de RNA total}

Culturas de PA14 cultivadas overnight a $37^{\circ} \mathrm{C}$ foram centrifugadas por 15 min a $5.500 \mathrm{rpm}$ a temperatura ambiente. Cada pellet bacteriano foi ressuspendido em $1 \mathrm{ml}$ de Trizol ${ }^{\circledR}$ e aquecido a $65{ }^{\circ} \mathrm{C}$ por $10 \mathrm{~min}$. Posteriormente, foram acrescentados $200 \mu \mathrm{l}$ de clorofórmio a cada amostra e elas foram misturadas manualmente de forma vigorosa. Cada amostra foi incubada a temperatura ambiente por 5 min e depois foi centrifugada a $12.000 \mathrm{rpm}$ por $15 \mathrm{~min}$ a $4{ }^{\circ} \mathrm{C}$. Em seguida, $580 \mu \mathrm{l}$ do sobrenadante foi tratado com 1 volume de isopropanol. Cada amostra foi incubada a $-80{ }^{\circ} \mathrm{C}$ por $30 \mathrm{~min}$ e, em seguida, centrifugada a $12.000 \mathrm{rpm}$ por $10 \mathrm{~min}$ a $4{ }^{\circ} \mathrm{C}$. O pellet foi lavado com $1 \mathrm{ml}$ de etanol $75 \%$ e recentrifugado por $5 \mathrm{~min}$ a $12.000 \mathrm{rpm}$ a $4{ }^{\circ} \mathrm{C}$. O RNA foi seco por $10 \mathrm{~min}$ a 
temperatura ambiente e ressuspendido em $50 \mu \mathrm{l}$ de $\mathrm{dH}_{2} \mathrm{O}$. A qualidade de cada extração foi avaliada em gel de agarose 1,2\%/formaldeído (2,2 M), e o RNA foi quantificado espectrofotometricamente.

\subsection{Detecção do transcrito hemB-ppk por RT-PCR}

Na identificação de um longo transcrito que inclui os genes hemB e $p p k$ foram usados os oligonucleotídeos descritos na Tabela 2. Foi extraído o RNA total a partir de uma cultura de PA14 cultivada em meio mínimo de fosfato (-Pi) até uma $\mathrm{DO}_{600}$ de aproximadamente 0,5. Para remover qualquer contaminação de DNA, foi realizado um tratamento com DNase (DNA-free ${ }^{\mathrm{TM}}$ Kit, Ambion) a 8,5 $\mu \mathrm{g}$ de RNA. O tratamento enzimático foi repetido até não ser observada nenhuma banda de amplificação em uma PCR convencional. O RNA foi quantificado espectrofotometricamente.

Cada mix da reação de transcrição reversa foi preparado em um volume de $20 \mu$, contendo: $4 \mu \mathrm{l}$ de ImProm-II 5X Reaction Buffer (Promega), 1,5 mM de $\mathrm{MgCl}_{2}$ (Promega), 0,5 mM de cada dNTP (Eppendorf), 20 unidades de Recombinant RNasin ${ }^{\circledR}$ Ribonuclease Inhibitor (Promega), 7,8 $\mu \mathrm{l}$ de água do kit, $1 \mu \mathrm{ImProm-II}{ }^{\mathrm{TM}}$ Reverse Transcriptase (Promega), 0,46 $\mu \mathrm{g}$ de RNA (livre de DNA) e 15 pmol do respectivo oligonucleotídeo reverso, (PA14-hemB (g)-R ou PA14-ppk(g)-R). Foram utilizados dois controles negativos por cada conjunto de oligonucleotídeos: um continha o mesmo mix de acima, exceto a enzima transcriptase reversa e, o outro, o mix sem RNA molde. O cDNA foi sintetizado por incubação de 1 hora a $42{ }^{\circ} \mathrm{C}$. Posteriormente, a enzima foi inativada a $70{ }^{\circ} \mathrm{C}$ por 15 min. A seguir, o cDNA sintetizado foi amplificado através de uma PCR convencional junto com os produtos dos controles empregando-se o seguinte programa térmico: 2 min a $94{ }^{\circ} \mathrm{C}$ e 30 ciclos de $30 \mathrm{~s}$ a $94{ }^{\circ} \mathrm{C}, 30 \mathrm{~s}$ a $55^{\circ} \mathrm{C}$ e $90 \mathrm{~s}$ a $74{ }^{\circ} \mathrm{C}$, com uma extensão final de 10 min a $74{ }^{\circ} \mathrm{C}$. Cada produto de PCR foi visualizado em um gel de agarose $1 \%$.

\subsection{Determinação do padrão de transcrição do operon pst de Pseudomonas aeruginosa por northern blot}

Culturas de PA14 foram cultivadas em meio mínimo de fosfato (+Pi) e (-Pi) até uma $\mathrm{DO}_{600}$ de aproximadamente 0,6 . Em seguida, foi realizado um ensaio de atividade da fosfatase alcalina para confirmar que as culturas cultivadas em meio limitado de Pi já houvessem atingido a fase de carência. Posteriormente, foi realizada a extração de RNA das culturas. 


\subsubsection{Eletroforese em gel de agarose/formaldeído}

Em um gel de agarose 1,4\% com formaldeído 2,2 M foram carregados $20 \mu \mathrm{g}$ de RNA por poço, com tampão de carga (2X RNA Loading Dye, Thermo Scientific). Foram utilizados dois marcadores de peso molecular de RNA: 0,2-6,0 kb (Thermo Scientific) e 0,16-1,77 kb (Invitrogen). A corrida eletroforética foi feita a $120 \mathrm{~V}$ por 2,5 horas. Finalmente, o gel foi fotodocumentado em transiluminador.

\subsubsection{Transferência do RNA para a membrana}

O gel foi lavado três vezes com $\mathrm{dH}_{2} \mathrm{O}$ em intervalos de 10 min e incubado em tampão SSC 10X (1,5 M de $\mathrm{NaCl}$ e 0,15 M de citrato de sódio dihidratado) por $45 \mathrm{~min}$. Uma membrana de náilon neutra (GeneScreen Hybridization Transfer Membrane, NEN DuPont) foi lavada brevemente em $\mathrm{dH}_{2} \mathrm{O}$ e em tampão SSC 10X por 15 min. Em seguida, o RNA foi transferido por capilaridade para a membrana por 12 horas com o esquema de transferência descrito em (STREIT et al., 2009). Após a transferência, o RNA foi fixado à membrana pela exposição a radiação UV de comprimento de onda de $254 \mathrm{~nm}$ por 10 min. Por fim, a membrana foi seca por 30 min a $80{ }^{\circ} \mathrm{C}$ no Gel Dryer Model 583 (Bio-Rad).

\subsubsection{Preparação das sondas}

Foram utilizadas sondas biotiniladas correspondentes a regiões internas dos genes $p s t S$, pstC e phoU. Na amplificação das sondas de DNA, o programa térmico empregado foi: 2 min a $94^{\circ} \mathrm{C}$ e 35 ciclos de 30 s a $94{ }^{\circ} \mathrm{C}, 30$ s à temperatura indicada na Tabela 2 , de acordo com o conjunto de oligonucleotídeos usados, e 1 min a $74{ }^{\circ} \mathrm{C}$ com uma extensão final de 10 min a $74^{\circ} \mathrm{C}$. Cada produto de PCR foi purificado e quantificado no espectrofotômetro.

Na marcação do DNA foi utilizado o kit Biotin DecaLabel DNA Labeling (Thermo Scientific). Foi marcado $1 \mu \mathrm{g}$ de cada produto de PCR purificado, segundo recomendações do fabricante.

\subsubsection{Prehibridização, hibridização e detecção}

Cada membrana contendo o RNA total foi colocada na solução de prehibridização (0,5 M de tampão de $\mathrm{Na}_{2} \mathrm{HPO}_{4} / \mathrm{H}_{3} \mathrm{PO}_{4}, 1 \mathrm{mM}$ de EDTA e $7 \%$ de SDS, pH 7,2) a $70{ }^{\circ} \mathrm{C}$ por 2,5 horas. Em seguida, foram adicionadas as sondas desnaturadas. A hibridização foi realizada a $55{ }^{\circ} \mathrm{C}$ por 16 horas. As membranas foram então lavadas: uma vez com a solução A (SDS 1\% e SSC 1X) a temperatura ambiente e três vezes com a solução B (SDS 
$0,1 \%$ e SSC $0,5 \mathrm{X})$ a $68^{\circ} \mathrm{C}$. Cada membrana foi seca brevemente em papel Whatman e as sondas foram detectadas utilizando-se o kit Biotin Chromogenic Detection (Thermo Scientific) de acordo com as instruções do fabricante.

\subsection{Ensaio de retardo da mobilidade eletroforética (EMSA)}

\subsubsection{Amplificação de $p h o B$ e clonagem em pGEM ${ }^{\circledR}-\mathrm{T}$ Easy}

Foi amplificada a ORF de PhoB através de uma PCR empregando-se os oligonucleotídeos descritos na tabela 2 e as condições têrmicas a seguir: 2 min a $94{ }^{\circ} \mathrm{C}$ e 5 ciclos iniciais de $30 \mathrm{~s}$ a $94{ }^{\circ} \mathrm{C}, 30 \mathrm{~s}$ a $50{ }^{\circ} \mathrm{C}$ e $1 \mathrm{~min}$ a $74{ }^{\circ} \mathrm{C}$; e mais 20 ciclos empregando-se as mesmas condições descritas anteriormente, porém com uma temperatura de anelamento de $58{ }^{\circ} \mathrm{C}$. Como DNA molde empregou-se uma colônia fresca de PA14.

O fragmento amplificado foi purificado e clonado no vetor pGEM ${ }^{\circledR}-$ T Easy (Promega) $^{-}$ adotando as mesmas metodologias descritas em 4.3.2. O plasmídio recombinante resultante, carregando o gene $p h o B$, foi denominado pGEM-B.

\subsubsection{Subclonagem no vetor pET-28a $(+)$}

Foram digeridos os plasmídios pGEM-B e pET-28a (+) com as enzimas HindIII (Thermo Scientific) e NdeI (Thermo Scientific). Cada produto de digestão foi purificado excisando-se a banda correspondente em um gel de agarose $1 \%$ e quantificado espectrofotometricamente.

Na ligação entre o fragmento liberado, contendo a ORF de PhoB, com o vetor digerido pET-28a $(+)$ empregou-se a proporção 1:8 (vetor:inserto). A reação foi incubada a $16{ }^{\circ} \mathrm{C}$ overnight. Ato contínuo, a enzima foi inativada a $70{ }^{\circ} \mathrm{C}$ por $5 \min$ e $1 \mu \mathrm{l}$ do produto da ligação foi eletroporado em DH10B. As bactérias foram plaqueadas e incubadas overnight a $37{ }^{\circ} \mathrm{C}$ em L-ágar suplementado com canamicina. Colônias crescidas após esse tempo foram repicadas em novas placas da mesma composição.

Clones positivos foram confirmados através de uma PCR de colônia empregandose oligonucleotídeos que flanqueavam a região de clonagem. A construção resultante, o plasmídio pET-phoB-his(6x), foi sequenciado e eletroporado na cepa BL21 (DE3) de E. coli. 
4.15.3 Testes de expressão e solubilidade da proteína recombinante PhoB-His

\subsubsection{Mini ensaio de indução}

A partir de uma cultura de transformantes de BL21 (DE3) crescida overnight foram feitas subculturas por diluição em LB suplementado com canamicina, a uma $\mathrm{DO}_{600}$ de aproximadamente 0,050 . Uma cultura foi cultivada a $37{ }^{\circ} \mathrm{C}$ e outra a $30{ }^{\circ} \mathrm{C}$ até ambas atingirem uma $\mathrm{DO}_{600}$ de aproximadamente 0,9. Neste ponto, foi retirado $1 \mathrm{ml}$ de cada cultura, para servir de controle negativo (culturas não induzidas), e o restante da cultura foi tratado com IPTG a uma concentração final de $1 \mathrm{mM}$. As culturas foram cultivadas por mais 4 horas. Posteriormente, $1 \mathrm{ml}$ de cada cultura foi coletado e centrifugado a $8.000 \mathrm{rpm}$ por 5 min e o restante foi usado em ensaios de solubilidade, descritos na seção seguinte. Cada pellet foi ressuspendido em $50 \mu \mathrm{l}$ de tampão de aplicação 1X (50 mM de tris. $\mathrm{HCl}(\mathrm{pH}$ 6,8), $100 \mathrm{mM}$ de DTT, $2 \%$ de SDS, 0,1\% de azul de bromofenol e $10 \%$ de glicerol (v/v)) e aquecido em banho de água fervente por 3 min. As amostras foram centrifugadas a $13.000 \mathrm{rpm}$ por $5 \mathrm{~min}$. $10 \mu \mathrm{l}$ de cada sobrenadante foram aplicados no gel junto com o marcador de peso molecular SeeBlue ${ }^{\circledR}$ Plus2 Pre-Stained Standard: 4-250 kDa (tris-glicina, Life Technologies).

Na separação eletroforética (SDS-PAGE) foi utilizada acrilamida 15\%. A corrida eletroforética foi efetuada a $200 \mathrm{~V}$ por 2,75 horas. O gel foi corado por 4 horas com uma solução de azul de Coomassie R-250 (0,25\% de azul de Coomassie R-250, 50\% de metanol (v/v) e $10 \%$ de ácido acético glacial (v/v)) sob agitação branda a temperatura ambiente e descorado por 4 horas com uma solução de $50 \%$ de metanol (v/v) e $10 \%$ de ácido acético $(\mathrm{v} / \mathrm{v})$.

\subsubsection{Testes de solubilidade}

Para testar a solubilidade da proteína recombinante, $3 \mathrm{ml}$ das culturas induzidas com IPTG foram centrifugados a $8.000 \mathrm{rpm}$ por 5 min e o pellet foi ressuspendido em $700 \mu \mathrm{l}$ de tampão de lise gelado (50 mM de tris. $\mathrm{HCl}(\mathrm{pH} 8,0), 200 \mathrm{mM}$ de $\mathrm{NaCl}, 25 \%$ de sacarose, $1 \mathrm{mM}$ de $\mathrm{MgCl}_{2}$ e $5 \%$ de glicerol (v/v)). As amostras foram incubadas no gelo por 10 min. A seguir, a suspensão celular foi sonicada empregando-se o sonicador de células Sonics Vibra-Cell ${ }^{\mathrm{TM}}$ modelo CV 334, em banho de gelo por pulsos de $10 \mathrm{~s}$ com $20 \mathrm{~s}$ de intervalo entre cada pulso por 10 min e uma amplitude de 40\%. As amostras foram centrifugadas a $12.000 \mathrm{rpm}$ por $10 \mathrm{~min}$ a $4{ }^{\circ} \mathrm{C}$. Por fim, o sobrenadante foi guardado a $-20{ }^{\circ} \mathrm{C}$ (fração de proteína solúvel) e o pellet foi ressuspendido em $700 \mu$ l de tampão de 
lise gelado (fração de proteína insolúvel). Foram separados $15 \mu$ le cada fração em gel de poliacrilamida em condições desnaturantes (SDS-PAGE 15\%) misturados com $6 \mu$ lo Lane Marker Reducing Sample Buffer (5X) (Thermo Scientific) junto com o marcador de peso molecular Precision Plus ProteinTM Dual Color Standards (Bio-Rad).

4.15.4 Purificação de PhoB-His recombinante por cromatografia de afinidade por íons metálicos imobilizados (IMAC)

O transformante BL21(DE3), contendo o plasmídio pET-phoB-his $(6 x)$, foi cultivado a $37{ }^{\circ} \mathrm{C}$ sob agitação de $150 \mathrm{rpm}$ overnight em LB suplementado com canamicina. Essa cultura foi, então, diluída em um volume de 1,5 l de LB suplementado com canamicina a uma $\mathrm{DO}_{600}$ inicial de aproximadamente 0,025 e cultivada a $30{ }^{\circ} \mathrm{C}$ sob agitação de $160 \mathrm{rpm}$ até uma $\mathrm{DO}_{600}$ de 0,6-0,7. Nesse ponto, foi acrescentado IPTG a uma concentração final de 0,5 mM e o crescimento foi mantido a $30{ }^{\circ} \mathrm{C}$ por um período de mais 4 horas. Em seguida, a cultura foi centrifugada a $5.000 \mathrm{rpm}$ por $10 \mathrm{~min}$. O pellet foi ressuspendido em $30 \mathrm{ml}$ de tampão de lise gelado contendo, adicionalmente, $1 \mathrm{mg} / \mathrm{ml}$ de lisozima e $10 \mathrm{mM}$ de imidazol. A suspensão bacteriana foi incubada a $30^{\circ} \mathrm{C}$ por 1 hora com agitação branda e depois foi mantida no gelo por pelo menos 15 min. A suspensão bacteriana foi sonicada em banho de gelo com pulsos de 20 s e 50 s de intervalo entre cada pulso a uma amplitude de $30 \%$ por 30 min. A suspensão com as células lisadas foi clarificada por centrifugação a 12.000 rpm por 15 min a $4{ }^{\circ} \mathrm{C}$. Posteriormente, o sobrenadante foi inserido na coluna HiTrap Chelating $H P(\mathrm{GE})$ de $5 \mathrm{ml}$ de Chelating Sepharose ${ }^{\mathrm{TM}}$ High Performance carregada com $\mathrm{NiSO}_{4}$ (300 mM) e equilibrada com tampão de ligação $(50 \mathrm{mM}$ de tris $\cdot \mathrm{HCl}(\mathrm{pH} 8,0), 200 \mathrm{mM}$ de $\mathrm{NaCl}$ e $10 \mathrm{mM}$ de imidazol), processo automatizado pelo emprego do equipamento ÄKTA start (GE). Após várias lavagens da coluna com tampão de ligação, a proteína recombinante PhoB-His foi eluída com tampão de eluição (50 mM de tris· $\mathrm{HCl}(\mathrm{pH} 8,0)$, $200 \mathrm{mM}$ de $\mathrm{NaCl}$ e $500 \mathrm{mM}$ de imidazol).

No processo de purificação, foram coletadas 10 frações de $5 \mathrm{ml}$ cada, cuja pureza foi avaliada por SDS-PAGE, como descrito em 4.15.3. As frações contendo a maior quantidade de proteína recombinante foram reunidas e dialisadas contra o tampão de armazenamento (50 mM de tris. $\mathrm{HCl}(\mathrm{pH} 7,0), 200 \mathrm{mM}$ de $\mathrm{NaCl}, 0,1 \mathrm{mM}$ de EDTA e 0,1 mM de DTT). Na diálise foi empregada a membrana SnakeSkin Dialysis Tubing (Thermo Scientific) de 3,5K MWCO. PhoB-His dialisada foi filtrada em filtro de 0,22 $\mu \mathrm{m}$, sua con- 
centração foi determinada utilizando-se o espectrofotômetro Epoch ${ }^{\mathrm{TM}}$, e foi estocada a $4{ }^{\circ} \mathrm{C}$.

\subsubsection{Fosforilação de PhoB-His}

A reação de fosforilação de PhoB-His foi baseada nas metodologias descritas em (MCCLEARY; STOCK, 1994; MCCLEARY, 1996). Brevemente, foi preparado o seguinte mix de reação em um volume de $1 \mathrm{ml}: 50 \mathrm{mM}$ de tris. $\mathrm{HCl}\left(\mathrm{pH}\right.$ 7,0), $20 \mathrm{mM}$ de $\mathrm{MgCl}_{2}, 0,1 \mathrm{mM}$ de DTT, $30 \mathrm{mM}$ de acetilfosfato (estoque preparado em $50 \mathrm{mM}$ de tris. $\mathrm{HCl}(\mathrm{pH} 7,0)$, $30 \mu \mathrm{M}$ de PhoB-His e $3,4 \mu \mathrm{l}$ de $\mathrm{dH}_{2} \mathrm{O}$. O mix foi incubado a $37{ }^{\circ} \mathrm{C}$ por 2 horas. A proteína fosforilada foi mantida a $4{ }^{\circ} \mathrm{C}$.

4.15.6 Marcação das extremidades dos fragmentos de DNA com $\left[\gamma^{-32} \mathrm{P}\right]$-ATP

Fragmentos de DNA correspondentes aos promotores dos genes $p s t S$, $p s t C$ e $p p x$ foram amplificadas por PCR. Empregaram-se os oligonucleotídeos descritos na Tabela 2, com o seguinte programa térmico: 2 min a $94{ }^{\circ} \mathrm{C}$ e 25 ciclos de $30 \mathrm{~s}$ a $94^{\circ} \mathrm{C}, 30 \mathrm{~s}$ à temperatura reportada na Tabela 2, de acordo com o conjunto de oligonucleotídeos usados, e $30 \mathrm{~s} \mathrm{a}$ $74^{\circ} \mathrm{C}$. Como DNA molde utilizou-se DNA cromossômico de PA14, extraído empregando-

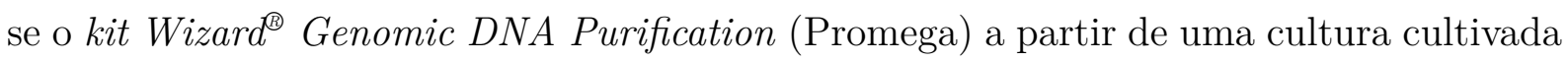
em meio LB a $37^{\circ} \mathrm{C}$ overnight. Cada produto de PCR foi separado em gel de agarose $1 \%$, seguido pela excisão de banda e purificação do DNA com o kit Wizard $^{\circledR} S V$ Gel and PCR Clean-Up System (Promega).

A marcação radioativa de cada sonda foi feita em um volume de $50 \mu \mathrm{l}$, contendo: 10 pmol de DNA, $5 \mu$ l de tampão 10X de T4 PNK (forward reaction, Thermo Scientific), 10 unidades de T4 PNK (Thermo Scientific), $6 \mu \mathrm{l}$ de $\left[\gamma-{ }^{32} \mathrm{P}\right]$-ATP 3,33 $\mu \mathrm{M}$ (PerkinElmer) e $\mathrm{dH}_{2} \mathrm{O}$ até completar o volume de reação. Cada mix de marcação foi incubado a $37^{\circ} \mathrm{C}$ por 90 min e a reação foi terminada utilizando-se $2 \mu \mathrm{l}$ de EDTA $0.5 \mathrm{M}$ (pH 8,0). A enzima foi inativada a $75{ }^{\circ} \mathrm{C}$ por $10 \mathrm{~min}$. Cada sonda radiomarcada foi purificada mediante precipitação com etanol e ressuspendida em $50 \mu \mathrm{l}$ de $\mathrm{dH}_{2} \mathrm{O}$. A incorporação radioativa de cada sonda foi determinada no cintilador líquido Tri-Carb B2910TR Liquid Scintillation Analyzer (PerkinElmer). As sondas radiomarcadas foram estocadas a $-20{ }^{\circ} \mathrm{C}$.

\subsubsection{Ensaio de retardo da mobilidade eletroforética (EMSA)}

Cada reação de interação foi feita em um volume final de $20 \mu \mathrm{l}$, contendo: $50 \mathrm{mM}$ de tris $\cdot \mathrm{HCl}(\mathrm{pH} 7,0), 10 \mathrm{mM}$ de $\mathrm{MgCl}_{2}, 1 \mathrm{mM}$ de DTT, $100 \mu \mathrm{g} / \mathrm{ml}$ de BSA, $4 \%$ de 
glicerol, $50 \mathrm{ng} / \mu \mathrm{l}$ de DNA de esperma de salmão e 0,5 mM de EDTA, proteína e sonda radiomarcada. No ensaio de EMSA, concentrações crescentes de PhoB-His fosforilada (0; $0,1 ; 0,3 ; 0,5 ; 0,7 ; 0,9 ; 5 ; 10 ; 15$ e $20 \mu \mathrm{M})$ foram adicionadas a um microtubo contendo o meio de interação sem sonda (ver acima). As proteínas foram incubadas no gelo por 15 min. Em seguida, aproximadamente $6.000 \mathrm{cpm}$ de DNA marcado (1 $\mu \mathrm{l}$ de sonda diluída) foram acrescentados e as reações foram incubadas a $37{ }^{\circ} \mathrm{C}$ por $30 \mathrm{~min}$. Após esse período, foram acrescentados $3 \mu \mathrm{l}$ de tampão de amostra 6X (DNA Loading Dye, Thermo Scientific) em cada reação e o DNA foi separado em gel de poliacrilamida $10 \%$ não desnaturante a $100 \mathrm{~V}$ em tampão TBE $1 \mathrm{X}$ a $4{ }^{\circ} \mathrm{C}$ por $90 \mathrm{~min}$. Posteriormente, os géis foram colocados sobre papel Whatman e foram secos no Gel Dryer Model 583 (Bio-Rad) por 1 hora e 20 min no vácuo. Cada gel foi então visualizado no Cyclone ${ }^{\circledR}$ Plus Storage Phosphor System (PerkinElmer) e pela exposição a um filme de raio-X. 


\section{RESULTADOS E DISCUSSÃO}

\subsection{Identificação do promotor principal do gene $p p k$ de PA14}

Tendo em vista que um dos objetivos deste projeto era investigar a regulação do promotor de $p p k$, foi necessário primeiro identificar a localização desse promotor. Há, aparentemente, uma discrepância na literatura a esse respeito: segundo (ZAGO et al., 1999), a sequência promotora de $p p k$ da cepa 8830 encontra-se na região intergênica entre os genes ppk e hemB (Figura 9a). Por outro lado, em PAO1, o promotor situa-se a montante do gene hemB (ISHIGE et al., 1998) (Figura 9b). A diferença na posição do promotor não apenas afetaria o tamanho e a regulação do transcrito, mas também alteraria o tamanho da ORF de ppk em cada cepa: em 8830, a proteína PPK teria 690 aminoácidos (ZAGO et al., 1999), enquanto que a PPK de PAO1 teria 736 aminoácidos (ISHIGE et al., 1998). O produto do gene hemB não está relacionado com o metabolismo de Pi: o gene codifica uma proteína envolvida na síntese de porfirinas (FRANKENBERG et al., 1998).

Segundo Ishige et al. (1998), predições computacionais mostraram que, em PAO1, o ATG de $p p k$ situa-se apenas 18 pb a jusante do códon de parada de hemB (Figura 9b). Portanto, sugeriu-se que o promotor de $p p k$ deve encontrar-se a montante de hem $B$, sendo talvez comum a ambos os genes. No entanto, na cepa 8830, ensaios de primer extension e predições computacionais mostraram que o códon de iniciação de ppk, GTG, situa-se mais a jusante, ou seja, 156 pb a jusante do códon de parada do gene hemB, o que resultaria em uma proteína com 46 aminoácidos a menos na porção N-terminal (ZAGO et al., 1999) (Figura 9a).

Se o promotor de $p p k$ for o mesmo de hemB, isso significa que os dois genes formam uma única unidade transcricional. Para esclarecer se hemB e $p p k$ formam um operon na cepa PA14, foi realizada uma análise de RT-PCR. Nessa análise, empregaram-se os oligonucleotídeos PA14-hemB(g)-R e PA14-ppk(g)-R, que correspondem a sequências específicas nas ORFs de hemB e ppk, respectivamente. O sítio de anelamento de cada oligonucleotídeo e os tamanhos dos produtos de amplificação esperados estão descritos na Figura 10.

O resultado da análise de RT-PCR evidenciou a presença de uma banda de aproximadamente 1,2 kb (Figura 10). Esse produto de amplificação deve corresponder ao transcrito de mRNA resultante da cotranscrição de $p p k$ com hemB. É possível concluir, portanto, 


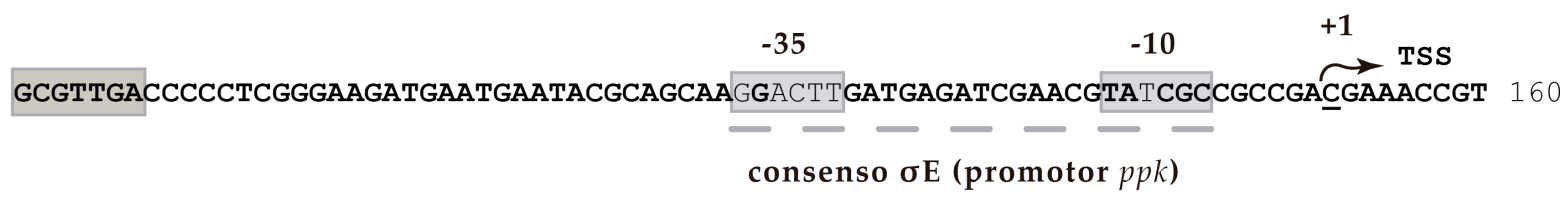

161 AGTGGCGAACGTGGAAAGCGAAGCAGAAGTGAAGATGGCCGAAACGATCCCGGTGGAAACGCCACCTGCGGTGGTTCCCA 240

SHINE-DALGARNO

241 GCGTGGATGACAGCAGCCTGTACATTCATCGCGAGCTCTCCCAGTTGCAGTTCAACATCCGCGTGCTGGAACAGGCGCTG 320 $\begin{array}{llllllllllllllllllllllllllllll}\mathrm{M} & \mathrm{D} & \mathrm{D} & \mathrm{S} & \mathrm{S} & \mathrm{L} & \mathrm{Y} & \mathrm{I} & \mathrm{H} & \mathrm{R} & \mathrm{E} & \mathrm{L} & \mathrm{S} & \mathrm{Q} & \mathrm{L} & \mathrm{Q} & \mathrm{F} & \mathrm{N} & \mathrm{I} & \mathrm{R} & \mathrm{V} & \mathrm{L} & \mathrm{E} & \mathrm{Q} & \mathrm{A} & \mathrm{L}\end{array}$

(a) Gene $p p k$ da cepa 8830 .

1 CTTACCGCCTTCAAACGTGCCGGCGCCGATGGCATTCTGACCTACTTCGCCAAGCAGGCCGCAGAACAATTAAGACGGGG 80

Final da ORF de hemB

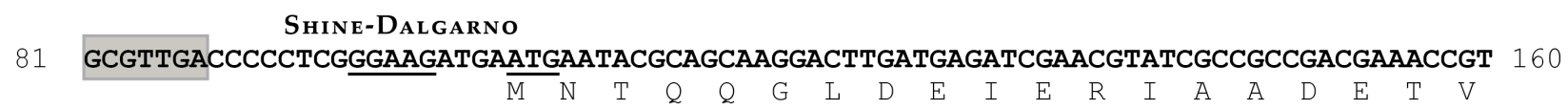

161 AGTGGCGAACGTGGAAAGCGAAGCAGAAGTGAAGATGGCCGAAACGATCCCGGTGGAAACGCCACCTGCGGTGGTTCCCA 240 $\begin{array}{llllllllllllllllllllllllllll}V & A & N & V & E & S & E & A & E & V & K & M & A & E & T & I & P & V & E & T & P & P & A & V & V & P & S\end{array}$

241 GCGTGGATGACAGCAGCCTGTACATTCATCGCGAGCTCTCCCAGTTGCAGTTCAACATCCGCGTGCTCGAACAGGCGCTG 320 $\begin{array}{llllllllllllllllllllllllll}V & D & D & S & S & L & Y & I & H & R & E & L & S & Q & L & Q & F & N & I & R & V & L & E & Q & A & L\end{array}$

(b) Gene $p p k$ da cepa PAO1.

Figura 9 - Sequência nucleotídica da porção 3' do gene hemB e 5' de $p p k$ nas cepas PAO1 e $\mathbf{8 8 3 0}$ de $\boldsymbol{P}$. aeruginosa. Aparecem sublinhadas as sequências Shine-Dalgarno putativas próximas ao códon de iniciação de tradução de PPK de cada cepa (ATG ou GTG). Na sequência correspondente à cepa 8830 aparece indicada a região promotora de $p p k$ : são mostrados o sítio de início da transcrição (TSS), determinado por primer extension (ZAGO et al., 1999), e os elementos putativos -35 e -10 reconhecidos pelo fator $\sigma^{\mathrm{E}}$. A sequência de aminoácidos de PPK predita é apresentada em baixo da sequência nucleotídica. Os números ao lado indicam o comprimento da sequência, e dentro de círculos cinzas aparecem marcados os SNPs encontrados. 


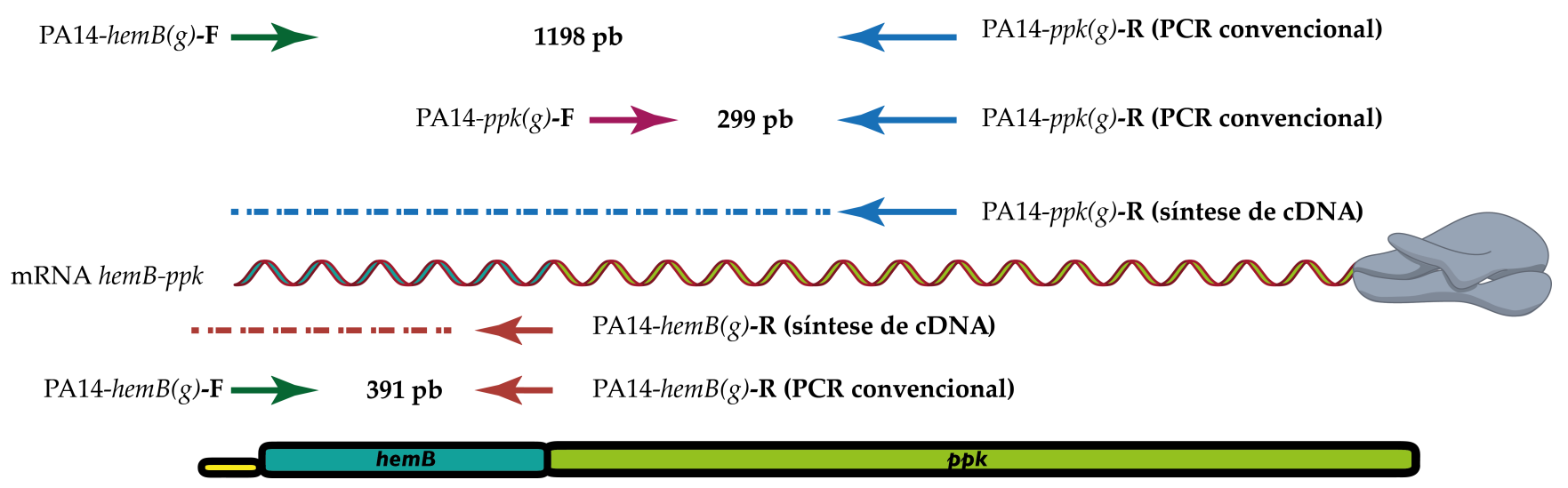

(a) Esquema representativo dos oligonucleotídeos empregados na RT-PCR. São apresentados também os tamanhos dos produtos de amplificação esperados.

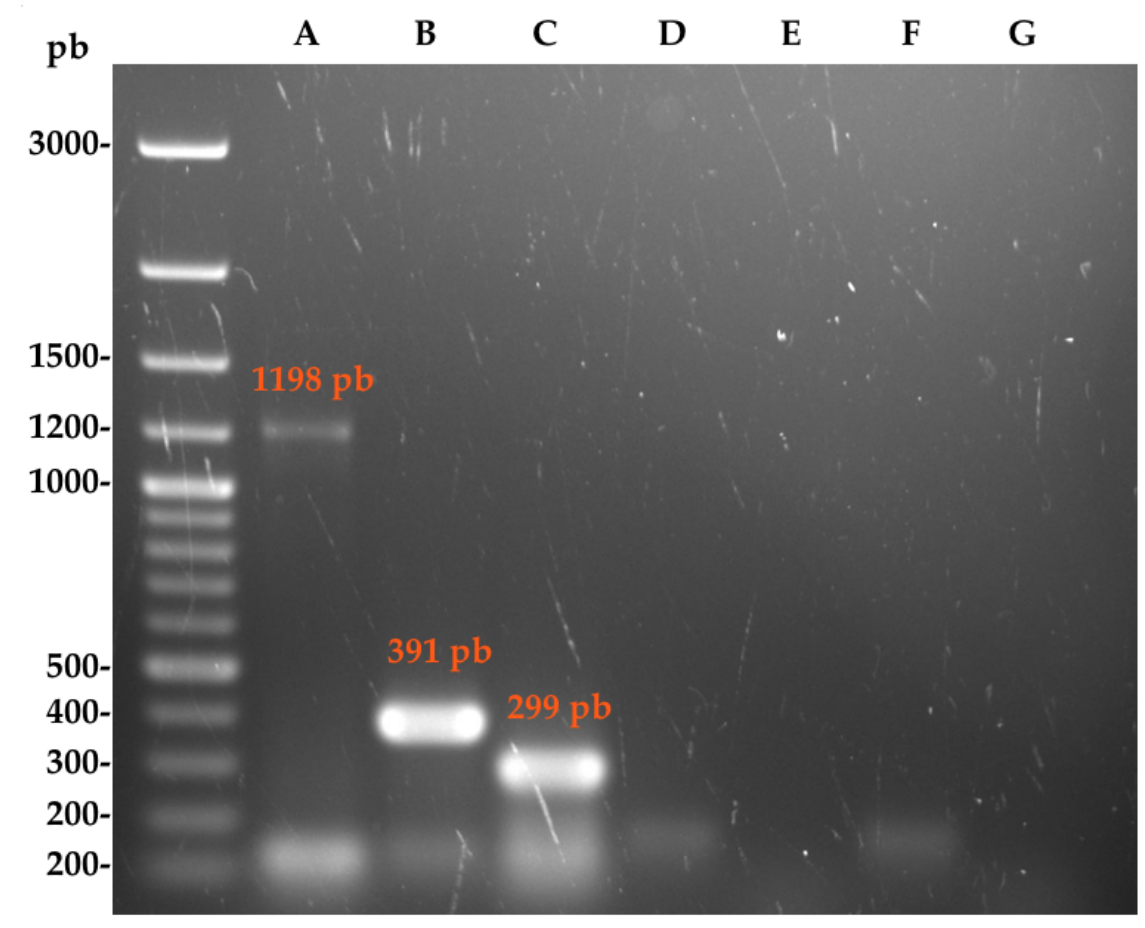

(b) Gel de agarose $1 \%$ com os produtos da análise por RT-PCR.

Figura 10 - Detecção do transcrito hemB-ppk. Em (a) são ilustrados os sítios de anelamento dos oligonucleotídeos utilizados na análise, assim como os tamanhos esperados dos produtos de amplificação correspondentes à etapa de PCR convencional. A imagem não está em escala. Em (b) observa-se o gel de agarose $1 \%$ com os produtos finais da reação de RT-PCR. A) produto hemB-ppk; B) produto hemB; C) produto $p p k$. Controles negativos: oligonucleotídeos PA14-hemB(g)-F/PA14-hemB(g)-R: D) RT-PCR sem transcriptase reversa; E) RT-PCR sem RNA molde; oligonucleotídeos PA14- $p p k(g)-\mathrm{F} / \mathrm{PA} 14-p p k(g)$ R: F) RT-PCR sem transcriptase reversa; G) RT-PCR sem RNA molde. 


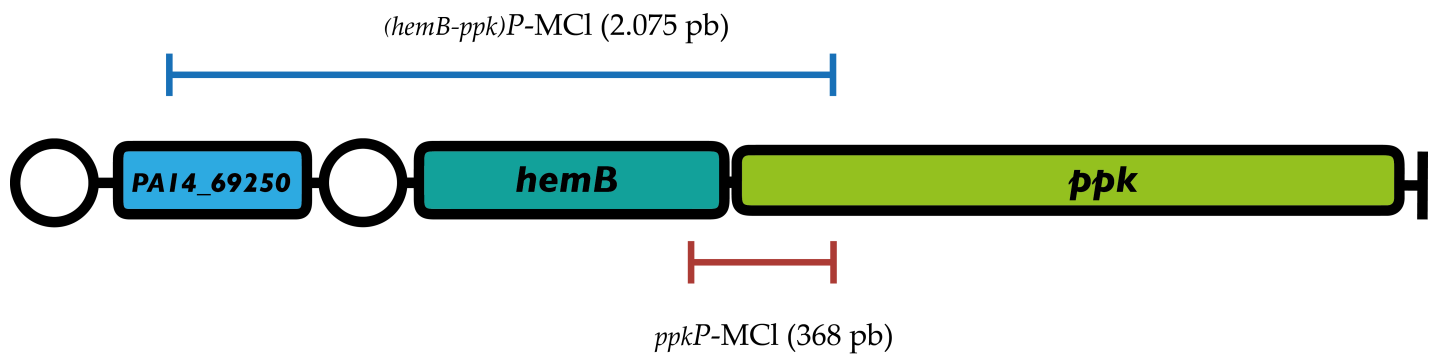

Figura 11 - Possível organização dos genes hemB e ppk no cromossomo de PA14. São mostradas as regiões clonadas no vetor mini-CTX-lacZ para a avaliação de atividade promotora mediante ensaios de $\beta$-galactosidase. Os círculos brancos representam regiões intergênicas.

que, em PA14, esses dois genes devem ser cotranscritos em um operon, como também foi sugerido para PAO1. Sendo assim, o promotor a montante de hemB provavelmente deve regular a expressão de $p p k$. Porém, isso não descarta a possibilidade de $p p k$ ser regulado por dois promotores: um promotor localizado a montante de hemB e o outro imediatamente a montante de $p p k$. A intensidade da banda de amplificação pertencente a esse transcrito é bem mais fraca do que as bandas correspondentes aos controles positivos. Essa diferença se deve ao fato de que a PCR de fragmentos pequenos é mais eficiente do que a de fragmentos grandes. Os controles negativos estão limpos, mostrando que todo o produto de amplificação por PCR foi gerado a partir de cDNA.

O próximo passo foi analisar a a atividade promotora a montante do gene hemB e imediatamente a montante do gene $p p k$. Com esse intuito, foram construídas duas fusões transcricionais no vetor Mini-CTX-lacZ (Figura 11): uma continha um fragmento de PCR de 2.075 pb englobando a porção 3' do gene PA14_69250 (localizado a montante de hem $B$ ), a totalidade do gene hemB e também a porção 5' do gene $p p k$. A outra construção continha um fragmento de 368 pb correspondente a 92 pb da região 3' do gene hemB e uma porção de 122 pb no 5' de $p p k$ (empregando-se o gene $p p k$ de 8830 como referência). As construções foram integradas no cromossomo de PA14, conforme descrito na seção 4.5. Finalmente, avaliou-se a expressão promotora desses fragmentos de DNA através de ensaios de $\beta$-galactosidase (Figura 12a). As culturas testadas foram cultivadas em meio DPMM +Pi e-Pi.

Os ensaios de $\beta$-galactosidase tornaram evidente a fraca atividade promotora da região localizada imediatamente a montante de $p p k$, avaliada por meio da fusão ${ }_{p p k} P$-lacZ . De 


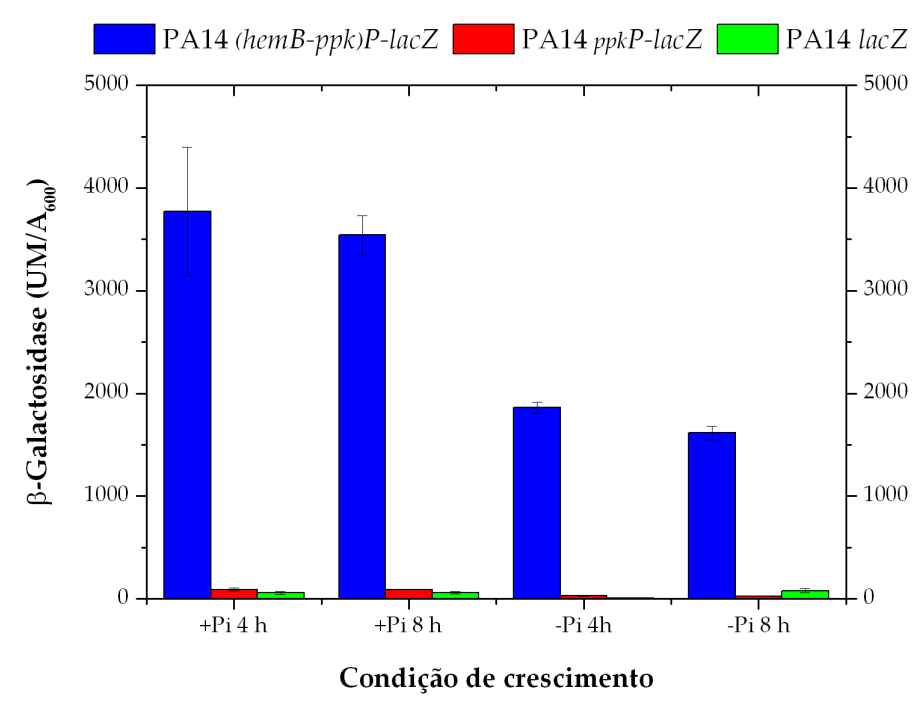

(a) Ensaio de $\beta$-galactosidase na determinação do promotor de $p p k$ em PA14.

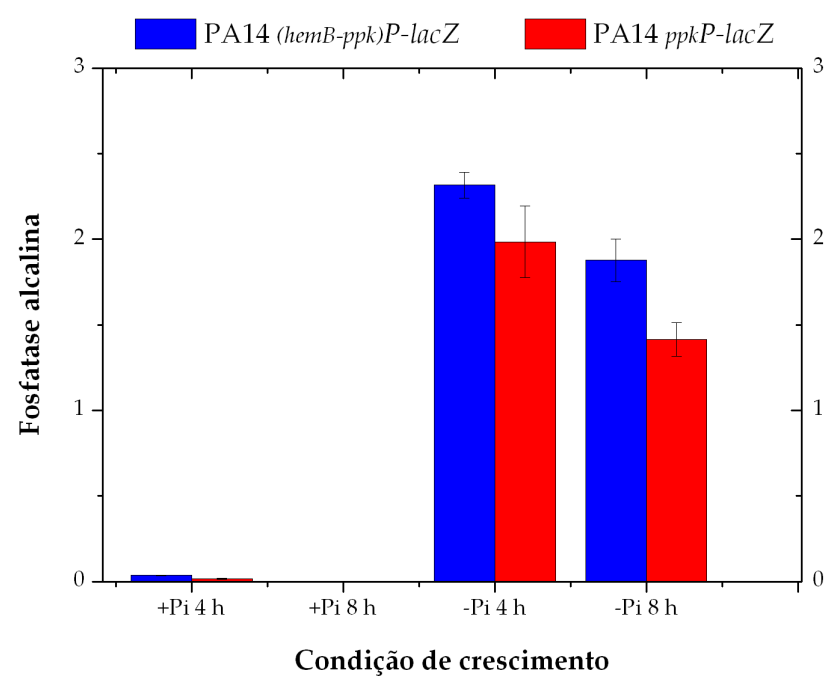

(b) Ensaio de fosfatase alcalina.

Figura 12 - Avaliação da atividade de dois possíveis promotores do gene $\boldsymbol{p} p \boldsymbol{k}$ em meio DPMM suficiente $(1 \mathbf{m M})$ e limitado $(0,2 \mathrm{mM})$ em Pi. Bactérias carregando as inserções cromossomais ${ }_{(h e m B-p p k)} P-l a c Z$ e ${ }_{p p k} P$-lacZ foram analisadas após 4 e 8 horas de crescimento em relação à atividade da $\beta$-galactosidase e fosfatase alcalina. Os valores apresentados e o desvio padrão da média correspondem a réplicas de três experimentos independentes.

fato, a expressão dessa fusão foi só ligeiramente maior que a expressão da $\beta$-galactosidase observada na cepa carregando o gene lac $Z$ sem promotor. No entanto, a fusão ${ }_{(h e m B-p p k)} P$ lac $Z$, que incluía o promotor de hemB, apresentou uma atividade promotora pelo menos 39 vezes maior do que a observada com a fusão ${ }_{p p k} P$-lacZ. Esse resultado sugere que na região promotora de hemB inicia-se a síntese de um longo mRNA que é transcrito até o final de $p p k$, não havendo nenhum terminador transcricional entre esses dois genes. Contudo, o promotor fraco, imediatamente a montante de $p p k$, poderia ter algum papel importante em alguma condição fisiológica desconhecida ainda não testada.

A atividade do promotor de hemB foi inibida em condições de carência de Pi. Este resultado indica que $p p k$ não pertence ao regulon Pho de PA14, assim como ocorre em E. coli (DIEN; KEASLING, 1999; MOROHOSHI et al., 2002; NEIDHARDT, 1996). A inibição da atividade promotora é provavelmente devida ao estresse nutricional causado pela carência de Pi, que causa a interrupção do crescimento e diminuição do metabolismo celular. Portanto, aparentemente, o promotor que regula a expressão de $p p k$ é ativado de forma constitutiva. De fato, análises da expressão de hemB mostraram que ele não é regulado por oxigênio, nitrato, heme ou ferro (FRANKENBERG et al., 1998), sendo que, seu 
promotor apresenta sequências consenso putativas -35 e -10 reconhecidas pelo fator $\sigma^{70}$, não havendo indícios da presença de outras sequências regulatórias (FRANKENBERG et al., 1998). Conforme esperado, a atividade da fosfatase alcalina aumentou de forma substancial nas bactérias limitadas em Pi (Figura 12b).

\subsection{Avaliação do efeito da mutação $p h o U$ sobre a regulação dos genes $p p k$ e ppx de PA14}

Para testar se a mutação phoU afeta a expressão de $p p k$ e de $p p x$, foram utilizados os plasmídios integrativos $\left(\right.$ hemB-ppk) $P-\mathrm{MCl}$ e ${ }_{p p x} P-\mathrm{MCl}$, inseridos no cromossomo da cepa selvagem e do mutante phoU. A atividade promotora foi inicialmente avaliada em meio DPMM +Pi (meio mínimo suficiente em Pi). Como observado na Figura 13, a expressão de ${ }_{p p k} P$-lacZ foi 4,9 vezes maior no mutante $p h o U$ do que na cepa selvagem durante as duas primeiras horas de crescimento. Daí em diante, essa diferença caiu para um pouco mais do dobro. Já em relação a ${ }_{p p x} P$-lac $Z$, o mutante $p h o U$ apresentou 5 a 9 vezes menos atividade do que a cepa selvagem durante a fase exponencial de crescimento, e aproximadamente duas vezes menos no começo da fase estacionária. Ambos os promotores apresentaram um nível basal de atividade não desprezível, que foi aumentando conforme as bactérias iam entrando na fase estacionária. Esse dado é compatível com o que se sabe sobre a atividade desses genes em $E$. coli, na qual a expressão do operon $p p k-p p x$ aumenta na fase estacionária (JUNG et al., 2012).

Alguma das limitações que dificultaram o planejamento desses experimentos foi a falta de informações na literatura no que diz respeito à regulação dos genes $p p k$ e $p p x$ de $P$. aeruginosa, e até mesmo de E. coli. Embora já tenham sido descritos os estímulos ambientais que levam ao acúmulo de poliP, eles nem sempre afetam a expressão de $p p k$ e/ou de $p p x$ ao nível de transcrição (JUNG et al., 2012).

Em E. coli, foi observado o rápido acúmulo de poliP em resposta aos estresses osmótico e nutricional (limitação de nitrogênio ou Pi e aminoácidos) (AULT-RICHÉ et al., 1998; RAO et al., 1998). Já em P. aeruginosa, o acúmulo de poliP foi evidenciado em condições de limitação de Pi e aminoácidos (AULT-RICHÉ et al., 1998). Portanto, esses fatores de estresse poderiam representar o estímulo necessário para aumentar de forma significativa a transcrição de $p p k$ e/ou de $p p x$. De fato, foi mostrado que a limitação de Pi ou de nitrogênio estimula a transcrição de $p p x$ em PAO1 (GALLARATO et al., 


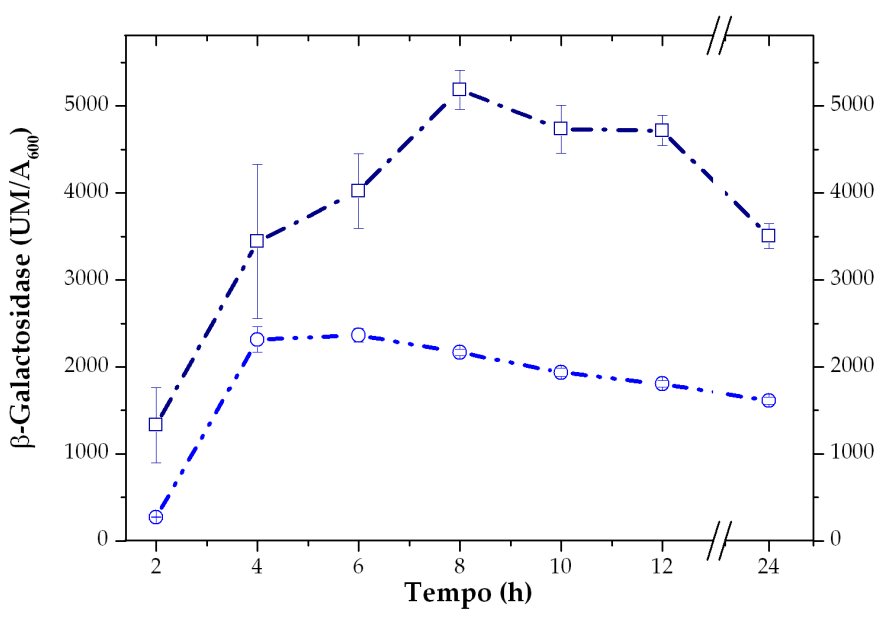

- o- PA14 (hemB-ppk)P-lacZ - $-p_{\text {hou }}^{-}{ }_{(h e m B-p p k) P-l a c Z}$

(a)

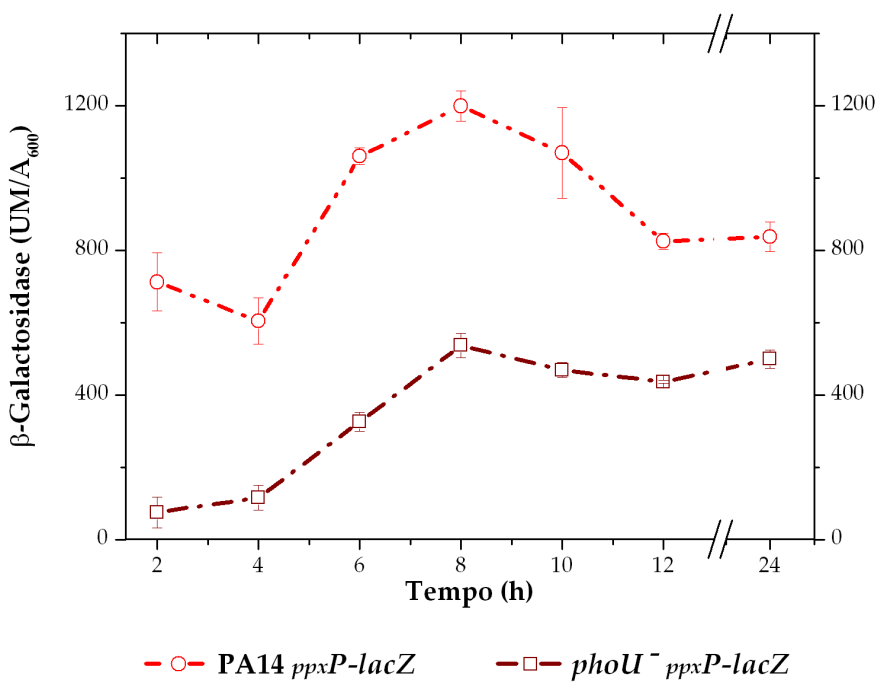

(b)

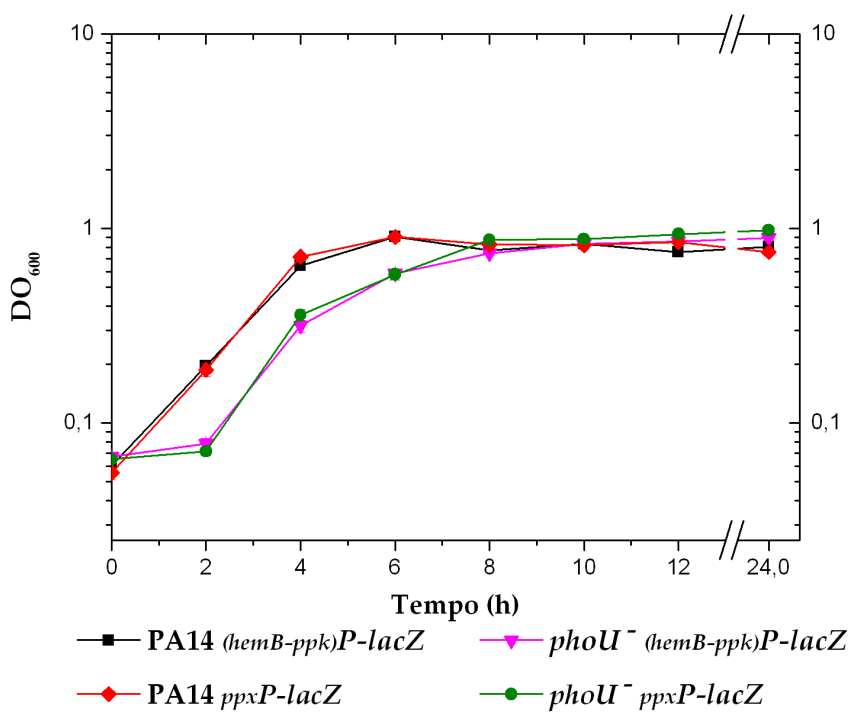

(c)

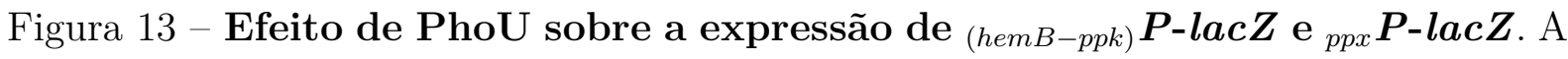
cepa selvagem PA14 e o mutante phoU, carregando as inserções cromossomais $\left(\right.$ hemB-ppk) $P$-lacZ e ${ }_{p p x} P$-lacZ, foram cultivadas em meio DPMM suficiente em Pi (1 mM). A expressão das fusões foi avaliada a cada 2 horas em ensaios de $\beta$-galactosidase. Os valores apresentados e o desvio padrão da média correspondem a três experimentos independentes. 


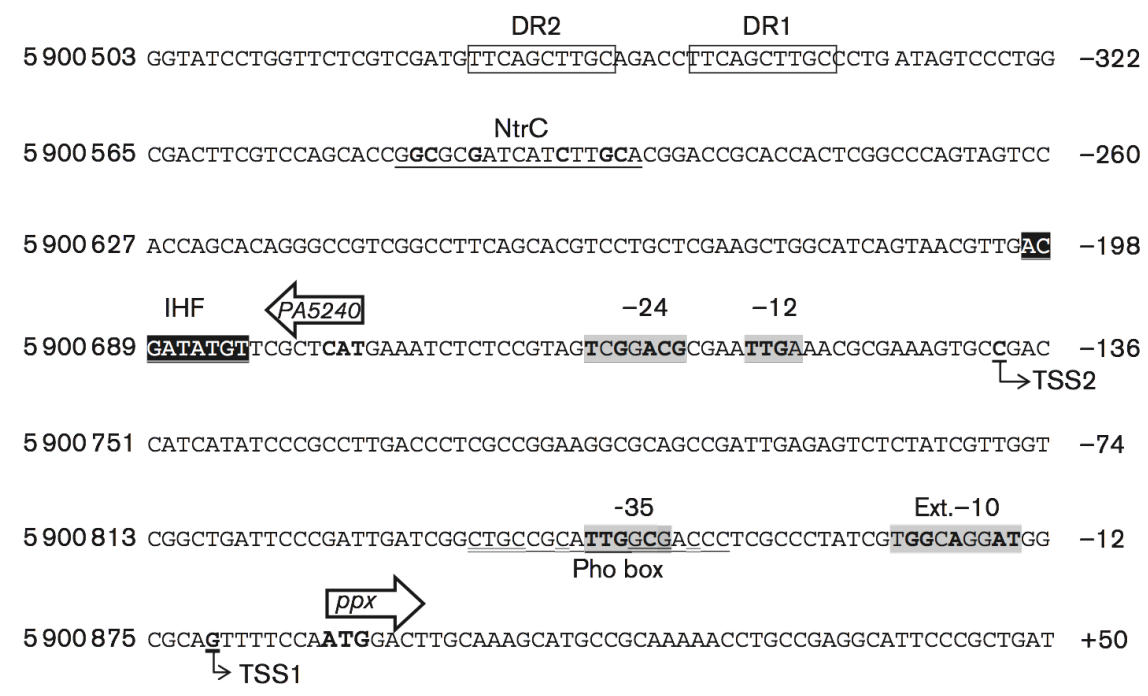

Figura 14 - Sequências consenso na região promotora necessárias à regulação do gene $\boldsymbol{p p x}$ de $\boldsymbol{P}$. aeruginosa PAO1. Fonte: (GALLARATO et al., 2014).

2014). Esses autores descreveram na região promotora de $p p x$ uma sequência consenso de ligação da proteína ativadora NtrC, e uma sequência promotora reconhecida pelo fator $\sigma^{54}$ (Figura 14). Foi identificada também uma sequência Pho box putativa próxima a uma possível região -10. Para corroborar esses dados, a expressão de ${ }_{(h e m B-p p k)} P$-lacZ e ${ }_{p p x} P$-lacZ também foi avaliada em condições de limitação de Pi ou de nitrogênio.

Para induzir nas bactérias uma resposta fisiológica à limitação de nitrogênio, empregouse a metodologia descrita em (WENNER et al., 2013). Dessa forma, as bactérias foram cultivadas em meio DPMM suplementado com $\mathrm{NO}_{3}^{-}$ao invés de $\mathrm{NH}_{4}^{+}$, a forma química preferencial de nitrogênio. $\mathrm{NO}_{3}^{-}$não é uma boa fonte de nitrogênio, pois não é eficientemente captado pela bactéria (KIRCHMAN, 1994; WENNER et al., 2013). A expressão promotora de ${ }_{(h e m B-p p k)} P$-lacZ e ${ }_{p p x} P$-lacZ foi avaliada 4 horas (fase exponencial) e 8 horas (fase de carência nutricional) após a diluição das bactérias nos meios limitantes.

O padrão de expressão da $\beta$-galactosidase de ${ }_{(\text {hemB-ppk) }} P$-lacZ nas cepas cultivadas em meio DPMM -Pi assemelha-se ao observado em meio DPMM +Pi, sendo a expressão de ${ }_{(h e m B-p p k)} P$-lacZ no mutante $p h o U$ maior do que na cepa selvagem (Figura 15a). Em meio limitado em N, observou-se pouca diferença entre a cepa selvagem e o mutante phoU em relação à expressão dessa fusão. Com referência à fusão ${ }_{p p x} P$-lacZ, a cepa selvagem apresentou maior atividade em todos os casos, quando comparada ao mutante phoU, especialmente nos meios $-\mathrm{N}$ e $+\mathrm{Pi}$ (Figura 15b). O mutante phoU apresentou expressão constitutiva da fosfatase alcalina, enquanto que a cepa selvagem apresentou alta atividade 


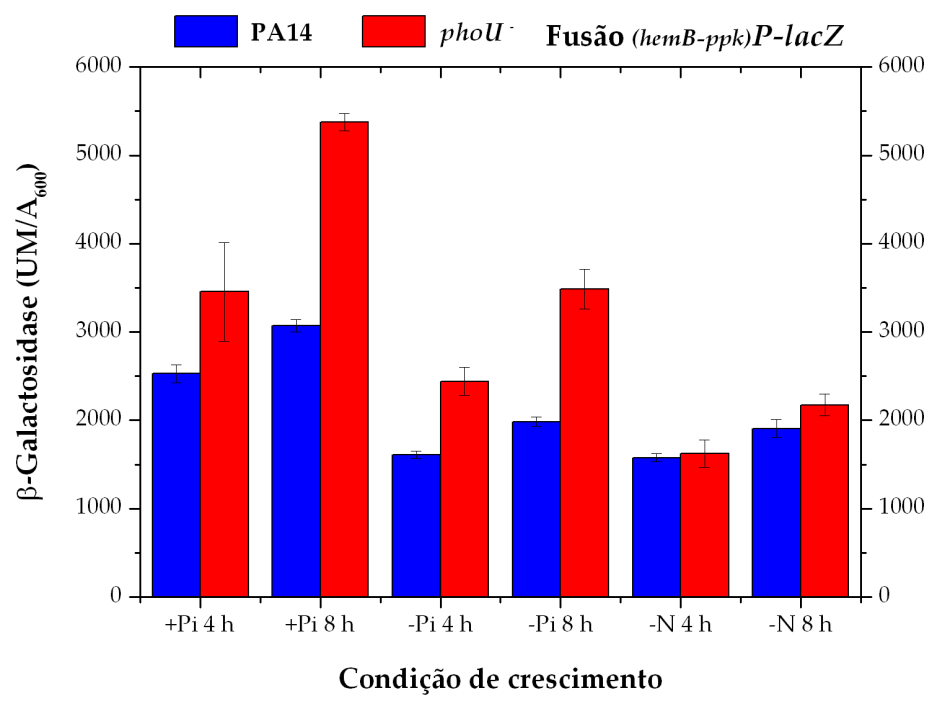

(a) Ensaios de $\beta$-galactosidase em PA14 e o mutante phoU carregando a inserção cromossomal (hemB-ppk) $P-l a c Z$.

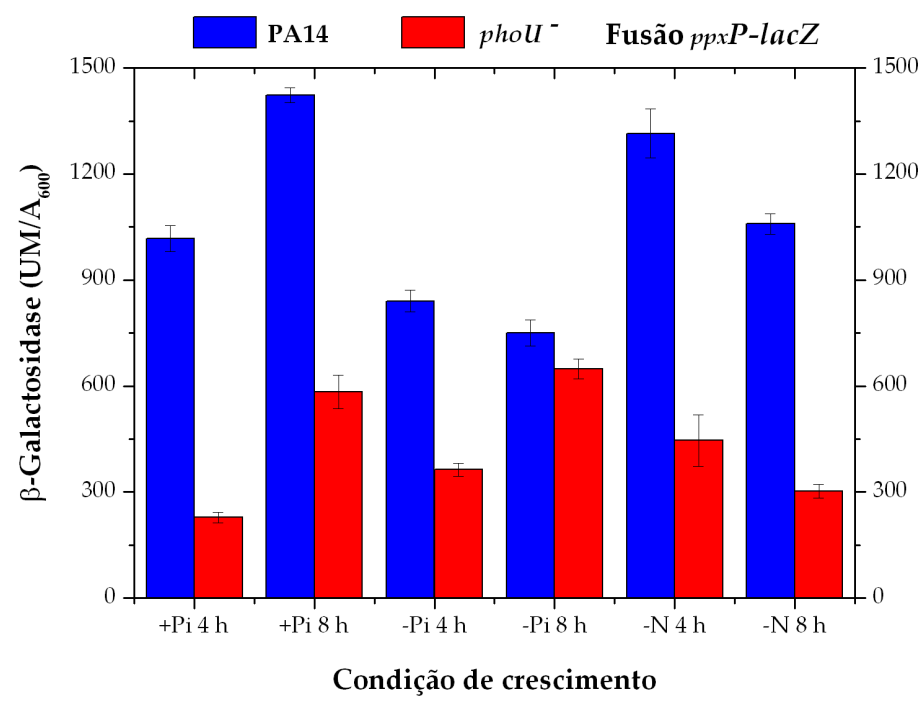

(b) Ensaios de $\beta$-galactosidase em PA14 e o mutante phoU carregando a inserção cromossomal ${ }_{p p x} P$-lacZ.

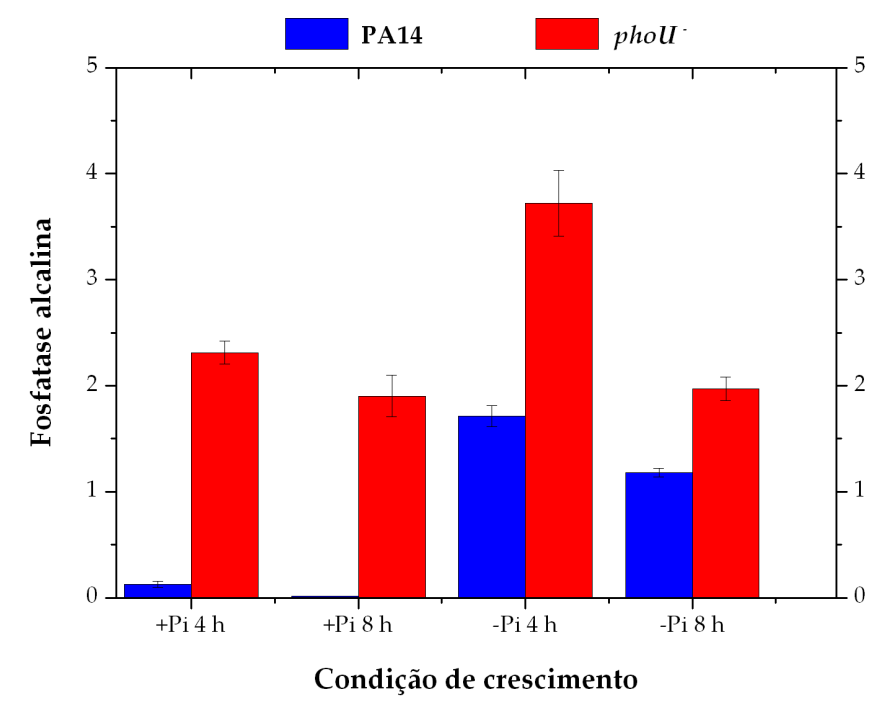

(c) Ensaio de fosfatase alcalina nas cepas carregando a inserção cromossomal ${ }_{(h e m B-p p k)} P-l a c Z$.

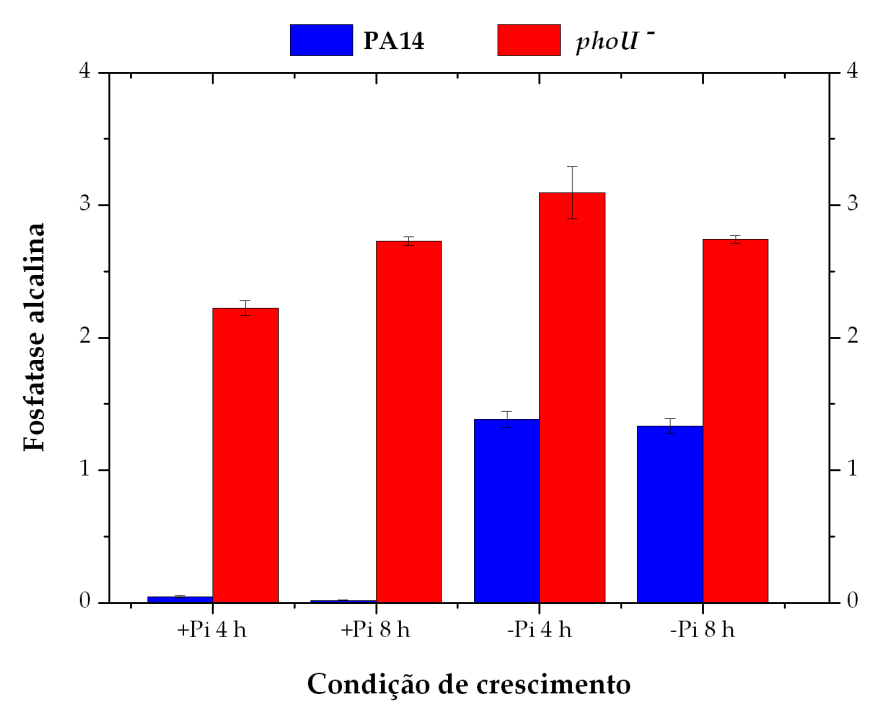

(d) Ensaio de fosfatase alcalina nas cepas carregando a inserção cromossomal ${ }_{p p x} P-l a c Z$.

Figura 15 - Efeito de PhoU sobre a expressão de ${ }_{(h e m B-p p k)} \boldsymbol{P}$-lac $\boldsymbol{Z} \mathbf{e}_{p p x} \boldsymbol{P}$-lac $\boldsymbol{Z}$ em diferentes condições de crescimento. Bactérias carregando as inserções cromossomais $\left(\right.$ hemB-ppk) $P$-lac $Z$ e ${ }_{p p x} P$-lac $Z$ foram cultivadas em meio DPMM $+\mathrm{Pi}$, -Pi e $-\mathrm{N}$ a $37^{\circ} \mathrm{C}$ e ensaiadas nos tempos de 4 e 8 horas para a atividade da $\beta$-galactosidase e fosfatase alcalina. Os valores apresentados e o desvio padrão da média correspondem a três experimentos independentes. 
da enzima somente na fase de carência de Pi, conforme esperado (Figura 15c-d).

Os resultados apresentados sugerem as seguintes conclusões:

1. Na ausência de $p h o U$ há aumento da expressão do gene $p p k$ e redução da expressão de $\boldsymbol{p p \boldsymbol { x }}$ : isto levaria a um maior acúmulo de poliP no mutante phoU, de acordo com o observado em (ALMEIDA et al., 2015). Pesquisas desenvolvidas em nosso laboratório demostraram que o mutante phoU, além de acumular poliP, acumula o nucleotídeo (p)ppGpp (ALMEIDA et al., 2015). Em E. coli, foi demonstrado que o (p)ppGpp inibe a atividade da proteína PPX in vitro (KURODA et al., 1997) e que quando se apresenta o acúmulo de poliP nessa bactéria, não há alteração aparente nas atividades de PPK e de PPX (KURODA et al., 1997). Portanto, foi proposto que o acúmulo de poliP no mutante phoU de $E$. coli seria consequência de uma diminuição na degradação enzimática do bipolímero devido à inibição da atividade de PPX causada por (p)ppGpp.

Em E. coli e em espécies relacionadas, $p p k$ e $p p x$ estão arranjados na forma de um operon. Por esse motivo, nessas bactérias pareceria realmente necessário algum tipo de regulação pós-transcricional que, através do desequilíbrio nos processos de síntese/degradação, levasse finalmente ao acúmulo de poliP. Todavia, em P. aeruginosa, $p p k$ e $p p x$ formam unidades transcricionais independentes. Desse modo, um aumento da transcrição de $p p k$ e uma diminuição da transcrição de $p p x$, como observado no mutante phoU neste trabalho, poderia gerar as condições necessárias para o acúmulo de poliP nesta bactéria. Além disso, haveria a contribuição de (p)ppGpp para o acúmulo de poliP através da inibição de PPX. Em conjunto, esses três fenômenos poderiam explicar por que $P$. aeruginosa acumula muito mais poliP do que E. coli.

2. A forma de regulação dos genes $p p k$ e $p p x$ é controversa: embora existam atualmente diversos trabalhos detalhando uma ampla variedade de estímulos que geram a síntese de poliP, há realmente pouca informação sobre a regulação transcricional e pós-transcricional dos genes $p p k$ e $p p x$. Além disso, as informações existentes não são conclusivas, e são comuns trabalhos com resultados contraditórios, tendo como exemplo: fusões transcricionais construídas com o promotor do operon $p p k-p p x$ de E. coli mostraram que se trata de um promotor fraco e constitutivo, cuja atividade aumenta ligeiramente em limitação de Pi, porém PhoR/PhoB 
não estão envolvidos nessa regulação (DIEN; KEASLING, 1999; JUNG, 2008). Por outro lado, (KATO et al., 1993) mostraram que uma fusão construída com o mesmo promotor parece indicar que a atividade de $p p k$ é dependente de PhoB.

Atualmente, sabe-se que genes envolvidos na síntese de purinas ativam a transcrição do operon $p p k-p p x$ em E. coli, e de $p p k$ em várias bactérias - K. pneumoniae, $V$. cholerae, Acinetobacter sp. ADP1 e S. typhimurium-(JUNG et al., 2012). Em Acinetobacter sp. foi observada a regulação de $p p k$ em limitação de $\mathrm{Pi}$, porém os dois promotores que regulam sua transcrição não apresentam sequências consenso reconhecidas por PhoB (GEISSDÖRFER et al., 1998). Em K. aerogenes, a sequência promotora de $p p k$ parece possuir um Pho box e sua regulação é dependente de PhoB (KATO et al., 1993). Em P. fluorescens, a transcrição de ppk é regulada por PhoB e por algum outro mecanismo desconhecido (SILBY et al., 2009).

A regulação de $p p x$ foi ainda menos estudada. GALLARATO et al. demonstraram que $p p x$ possui pelo menos dois tipos de controle a nível transcricional: um promotor que responde às limitações de nitrogênio, regulado pelo ativador $\mathrm{NtrC}$ e reconhecido pelo fator $\sigma^{54}$, e outro promotor que responde às carências/limitações de Pi regulado por PhoB. No entanto, os resultados aqui apresentados mostraram que nem $p p x$ nem $p p k$ têm sua expressão aumentada nessas condições. No caso de $p p x$, a cepa selvagem cultivada em meio deficiente em $\mathrm{N}$ apresentou um perfil de expressão similar ao da cultura em meio não limitado. Por outro lado, foi evidenciada uma ligeira queda na expressão de $p p x$ em meio limitado em Pi. Concluimos, portanto, que $p p k$ e $p p x$ são expressos a partir de promotores que não respondem à carência de Pi ou N.

Em (BAINS et al., 2012) estudaram o perfil de genes diferencialmente expressos na deficiência de $\mathrm{Pi}$ em $P$. aeruginosa PAO1 através da técnica de microarranjos. O resultado dessa análise mostrou que 842 genes tiveram sua expressão afetada pela deficiência de $\mathrm{Pi}$, dos quais 495 tiveram sua expressão aumentada e 347 diminuída. Um estudo similar de análise de transcriptoma foi realizado em (ZABORIN et al., 2009), no qual grande parte dos resultados coincidem com os dados da análise de microarranjos de (BAINS et al., 2012). Contudo, em nenhuma dessas duas análises de expressão gênica foram detectadas alterações nos níveis de expressão de $p p k$ (PA5242) ou de ppx (PA5241) em deficiência ou carência total de Pi. Em outra pesquisa, uma fusão transcricional do promotor de $p p x$ de $P$. aeruginosa 8830 com 
lacZ, não mostrou qualquer tipo de modulação na transcrição desse gene (ZAGO et al., 1999). Por fim, mutantes phoU de E. coli e de P. aeruginosa são caracteristicamente Pho constitutivos e acumuladores de poliP (ALMEIDA et al., 2015; MOROHOSHI et al., 2002). Portanto, se $p p x$ possuísse um Pho box, e ele respondesse positivamente à deficiência de $\mathrm{Pi}$, seria esperado que a expressão desse gene fosse afetada positivamente pela mutação phoU. Isso não foi observado nos ensaios de $\beta$-galactosidase com a cepa $p h o U^{-}{ }_{p p x} P$-lacZ em qualquer uma das condições nutricionais avaliadas. Além disso, a atividade aumentada da exopolifosfatase deveria degradar grande parte do poliP presente na bactéria, sendo seu acúmulo inatingível. Como isso não ocorre (ALMEIDA et al., 2015), concluímos que, pelo menos no caso da cepa PA14, ppx não deve ser ativado pela deficiência de Pi.

GALLARATO et al. identificaram uma possível sequência Pho box a montante de ppx, cuja identidade com o Pho box do gene phoX de P. fluorescens (MONDS et al., 2006), segundo eles, é de 64\%. Porém, uma rápida inspeção por BLAST (ALTSCHUL et al., 1990) permitiu verificar que a identidade é menor, de 50\% (Figura 16). Além disso, a jusante da suposta Pho box há apenas uma sequência -10 com baixíssima similaridade ao consenso TATAAT. Tomados todos esses dados em conjunto, em nossa opinião, a possibilidade de $p p x$ e/ou $p p k$ pertencerem ao regulon Pho de P. aeruginosa não parece ser muito provável.

\begin{tabular}{|c|c|c|c|}
\hline FONTE & ALINHAMENTO & Pho box & IDENTIDADE \\
\hline GALLARATO et al., 2014 & $\begin{array}{l}\text { CTGCCGCATTGGCGACCC } \\
|||||||||l| l|l| l|l| l\end{array}$ & & 9/18 (50\%) \\
\hline
\end{tabular}

Figura 16 - Alinhamento das sequências Pho box putativas presentes nos promotores de $p p x$ e phoX das espécies $P$. aeruginosa e P. fluorescens, respectivamente. Foi usada a ferramenta BLAST (ALTSCHUL et al., 1990) para o alinhamento das sequências. Fonte das sequências: (GALLARATO et al., 2014; MONDS et al., 2006). 


\subsection{Determinação do padrão de transcrição do operon pst de Pseudomonas aeruginosa}

\subsubsection{Detecção dos transcritos de pst por northern blot}

Um dos objetivos do projeto era analisar o padrão transcricional do operon pst de P. aeruginosa. Isso porque o sistema Pst é o principal meio de captação de Pi, sendo fundamental para o acúmulo de poliP e, também, porque phoU, cuja mutação é analisada neste trabalho, pertence ao operon pst. A técnica de northern blot é a única ferramenta que permite avaliar o tamanho dos transcritos de um operon. Para essa análise, foram utilizadas sondas de DNA biotiniladas que hibridizam com regiões internas dos transcritos de pstS, pstC ou phoU (Figura 17).

Apesar de diversas tentativas e diversas modificações no protocolo, conseguiu-se detectar apenas um produto de hibridização com a sonda $p s t S$, correspondendo a um transcrito de $0,97 \mathrm{~kb}$ (Figura 18). A partir desse transcrito deve ser codificada a proteína periplasmática PstS. O método cromogênico de detecção utilizado no ensaio de northern blot tem baixa sensibilidade, quando comparado com outros sistemas de detecção de sondas marcadas. Por esse motivo acreditamos que demais espécies de mRNA não foram detectadas.

Em outros operons que codificam sistemas de transporte do tipo $\mathrm{ABC}$, normalmente o transcrito mais abundante corresponde ao primeiro gene do operon, que codifica a proteína periplasmática de ligação ao substrato (HIGGINS et al., 1982; HORAZDOVSKY; HOGG, 1987). Em E. coli, o operon pst é transcrito em uma longa molécula de mRNA que, após sua síntese, é rapidamente processada, gerando moléculas de menor tamanho (AGUENA et al., 2002). Próximo da extremidade 3' do gene pstS, foi identificada uma sequência REP putativa que estabiliza essa região do mRNA, evitando sua degradação pela atividade de

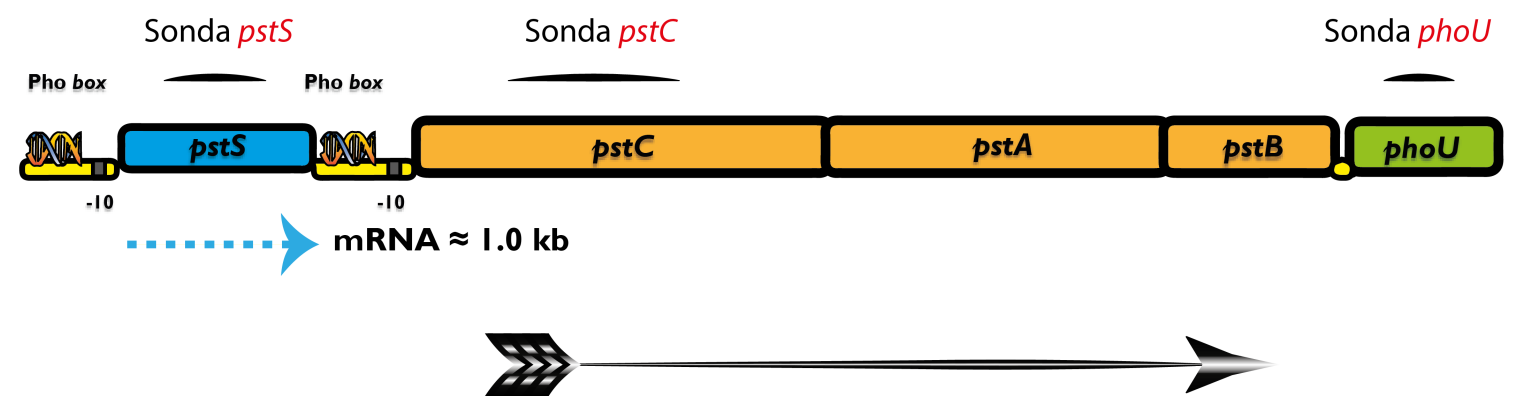

Figura 17 - Operon pst de $\boldsymbol{P}$. aeruginosa apresentando as regiões de amplificação por PCR das sondas de DNA utilizadas no ensaio de northern blot. A seta tracejada representa a transcrição da espécie de mRNA detectada correspondente ao transcrito de $p s t S$. 


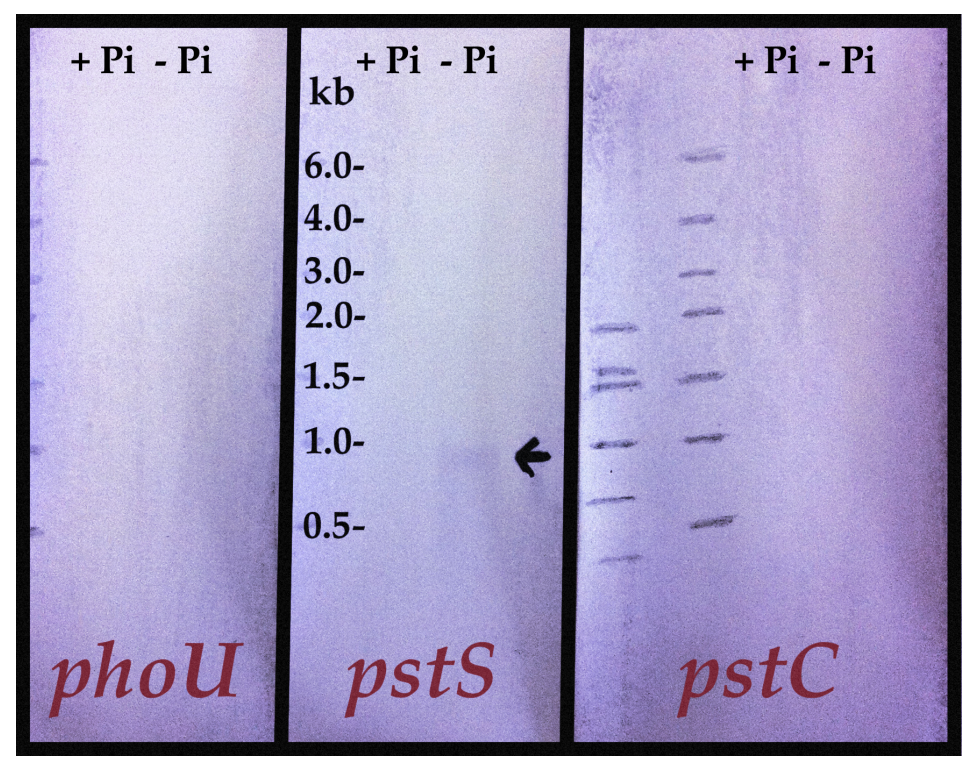

Figura 18 - Análise do operon pst por northern blot. Cada sonda biotinilada utilizada para hibridizar com os respectivos transcritos aparece identificada na membrana. O RNA foi extraído de culturas de PA14 cultivadas em meio DPMM em suficiência (+ Pi) ou deficiência (- Pi) de fosfato.

ribonucleases (AGUENA et al., 2002; AGUENA et al., 2008). Assim, o transcrito de pstS torna-se o mais abundante, quando comparado com os mRNAs correspondentes aos outros genes do operon. Isso também foi observado no operon pst da bactéria Gram-positiva $B$. subtilis (ALLENBY, 2004).

$\mathrm{Na}$ análise da transcrição do operon pst de outro bacilo Gram-positivo, Clostridium acetobutylicum, foram observados unicamente dois transcritos de mRNA de abundâncias diferentes: um correspondente ao gene $p s t S$, o mais abundante, e outro correspondente ao transcrito do operon completo (FISCHER et al., 2006). Nessa análise, mostrou-se que próximo do final do gene $p s t S$ existe uma sequência que poderia atuar como um terminador de transcrição. Portanto, em C. acetobutylicum, esse pequeno transcrito parece ser gerado pela terminação prematura de sua transcrição e não pelo processamento do longo mRNA.

A relativa abundância da proteína PstS, em comparação com os outros componentes do transportador Pst, poderia tornar o processo de captação de Pi mais eficiente, pois, como observado em outros transportadores ABC, a ligação da proteína periplasmática a seu substrato é geralmente o processo que limita a velocidade do transporte (PODBIELSKI et al., 1996). Além disso, um único canal intermembranal poderia ser utilizado por várias cópias da proteína periplasmática, aumentando a eficiência do transporte do nutriente (ALLENBY, 2004). 
Segundo a análise de microarranjos mencionada acima, foi observado que o gene pstS apresentou um nível de expressão de 8 a 12 vezes mais intenso do que os demais genes do operon pst nas limitações de Pi (BAINS et al., 2012). O operon pst de P. aeruginosa possui duas Pho box: um a montante de pstS e outro a montante de pstC (Figura 17). Essa independência transcricional permitiria à bactéria empregar uma estratégia diferente da observada em E. coli para modular, já no nível da transcrição, os níveis de expressão de pstS em relação aos demais genes do operon. Ou seja, haveria um terminador de transcrição imediatamente a jusante de $p s t S$ e, em seguida, viria o promotor de $p s t C$. Uma análise com o programa mfold (ZUKER, 2003) revelou a presença de um terminador de transcrição putativo 51 nt após o códon de parada de pstS e 43 nt antes da sequência Pho box a montante de $p s t C$. Esse aparente terminador apresenta uma haste de 9 pb composta por GCs, uma alça de 8 nt, e 3 uracilas próximas à região 3' do mRNA (Figura 19).

Embora só tenha sido observada uma banda de hibridização no northern blot, acreditamos que os demais transcritos possam ser detectados empregando-se essa técnica. No

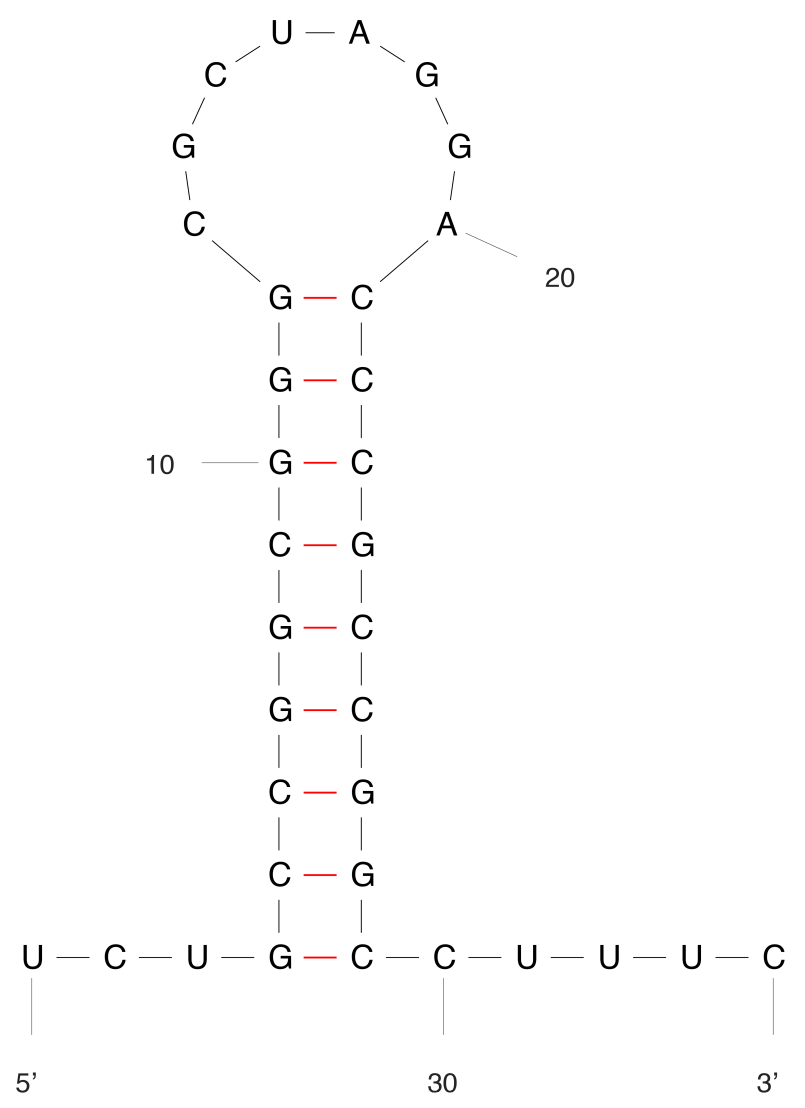

Figura 19 - Estrutura secundária com forma de grampo presente na região intergênica entre $\boldsymbol{p} \boldsymbol{s t} \boldsymbol{S}$ e $\boldsymbol{p} \boldsymbol{s t} \boldsymbol{C}$. O grampo apresenta uma haste de GCs e 3 uracilas próximas da região 3' do mRNA. 
futuro, serão aprimoradas as condições experimentais utilizando-se um kit de marcação e hibridização mais sensível ou sondas de DNA radiomarcadas.

\subsubsection{Identificação de um promotor alternativo a montante de $p h o U$}

No operon pst de E. coli, além do promotor principal, a montante de pstS, foram encontrados promotores internos de atividade fraca a montante de $p s t C$, pstB e phoU (SPIRA et al., 2010). Diferentemente do promotor principal, esses promotores atuam de forma constitutiva, mesmo quando a concentração de Pi no meio é alta. A expressão basal do promotor principal, em conjunto com a expressão constitutiva dos promotores internos, permitiria que o transportador Pst mantivesse um nível de transcrição mínimo e que contribuísse para o transporte de $\mathrm{Pi}$, mesmo quando a concentração do nutriente no meio fosse alta (SPIRA et al., 2010).

Complementando a análise do padrão de transcrição do operon pst de PA14, foi abordada a viabilidade da presença de promotores internos nesse operon. Foi inicialmente estudada essa possibilidade para o gene phoU, pois o foco de atenção da presente pesquisa recai particularmente sobre ele.

Para avaliar a existência de uma possível atividade promotora a montante de $p h o U$, foi amplificada uma região de $1.334 \mathrm{pb}$ que engloba parte de pstB e a região 5' de phoU (Figura 20). Esse fragmento de DNA foi clonado no vetor Mini-CTX-lacZ e o vetor resultante foi transformado em PA14. Bactérias carregando a fusão foram cultivadas em meio DPMM +Pi e -Pi.

Os ensaios de $\beta$-galactosidase mostraram que a expressão de ${ }_{p h o U} P$-lacZ foi de 4 a 10 vezes maior do que a observada na cepa carregando apenas um gene lacZ (Figura 21a), sendo ligeiramente maior em condições de abundância de Pi. Isto sugere que deve haver um promotor funcional constitutivo na região a montante de phoU. A atividade da fosfa-

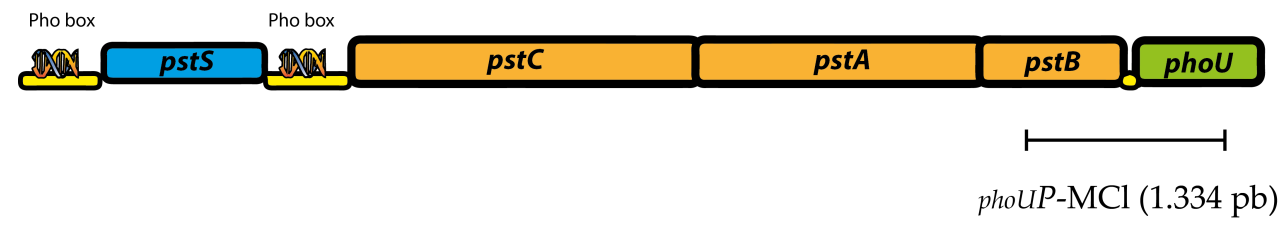

Figura 20 - Esquema do operon pst de PA14 no qual aparece indicada a região pstB-phoU amplificada por PCR e clonada no Mini-CTXlac $\boldsymbol{Z}$. A atividade promotora dessa região foi avaliada através de ensaios de $\beta$-galactosidase. 


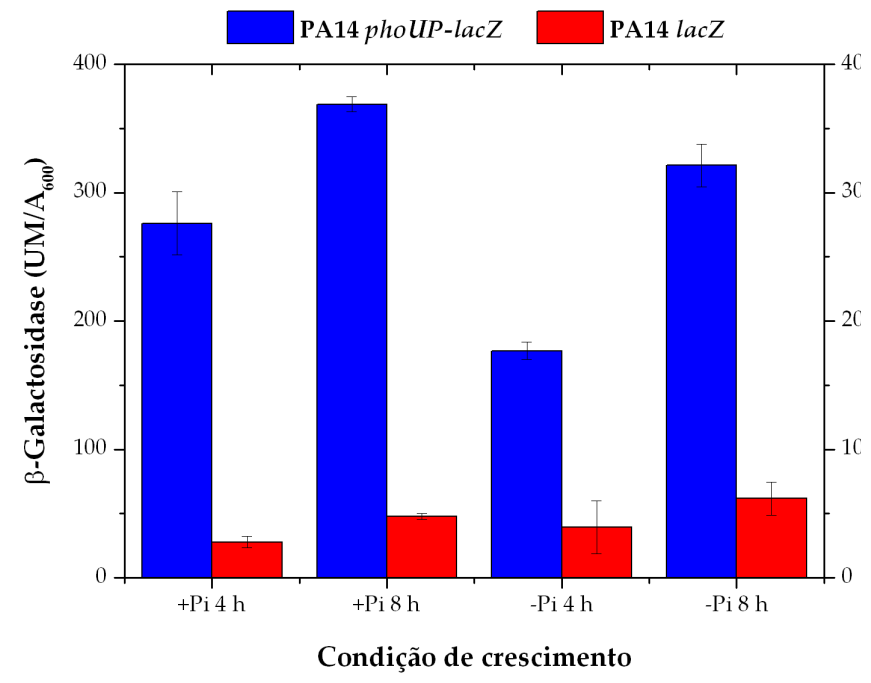

(a) Ensaio de $\beta$-galactosidase.

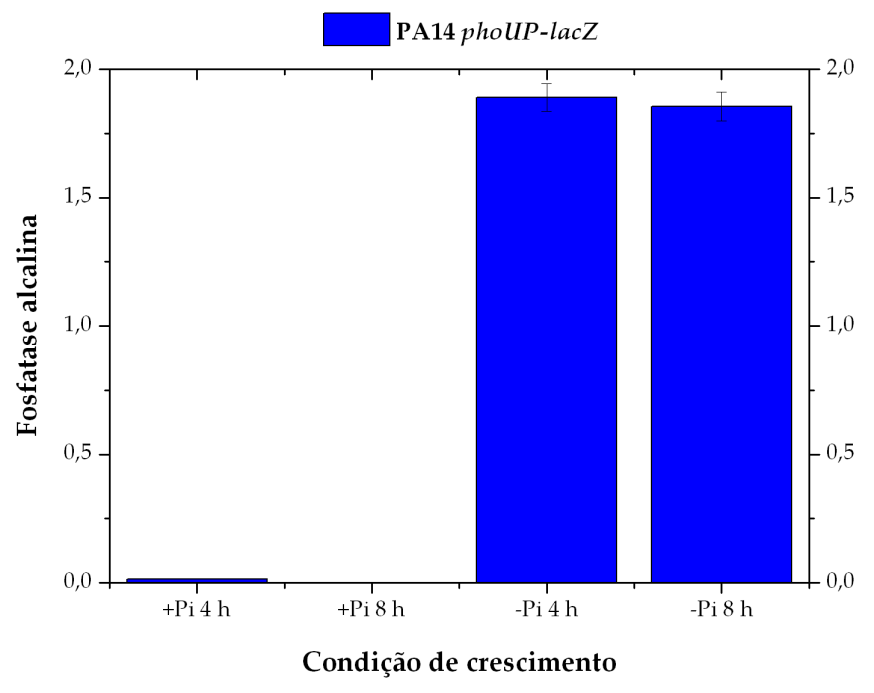

(b) Ensaio de fosfatase alcalina.

Figura 21 - Avaliação da atividade promotora na região imediatamente a montante de phoU. Bactérias foram cultivadas em meio DPMM +Pi e -Pi a $37^{\circ} \mathrm{C} .4$ e 8 horas após o início do crescimento, alíquotas de bactérias foram coletadas e avaliadas em ensaios de $\beta$-galactosidase. Foi também testada a atividade da fosfatase alcalina de cada cultura. Os valores apresentados e o desvio padrão da média correspondem a três experimentos independentes.

tase alcalina confirma que as culturas cultivadas em meio mínimo -Pi haviam entrado na fase de carência de Pi (Figura 21b).

Pode haver mais de um motivo para a presença de um promotor próprio constitutivo governando a transcrição de $p h o U$. A ausência de $p h o U$ foi associada a vários fenótipos distintos, tais como acúmulo de poliP, diminuição da resistência a antibióticos e aos estresses osmótico, oxidativo, térmico e nutricional, e menor persistência (LEE et al., 2009; LI; ZHANG, 2007; SHI; ZHANG, 2010; WANG et al., 2013). É possível que a expressão de phoU a partir de seu próprio promotor seja necessária para manter um nível de proteína PhoU suficiente para evitar os efeitos nocivos causados pela ausência de phoU. A atividade de PhoU não se limita ao seu papel de repressor do regulon Pho pois, na sua ausência, genes envolvidos em processos fisiológicos e metabólicos diferentes são afetados (LI; ZHANG, 2007).

Finalmente, no futuro espera-se caracterizar melhor o papel de phoU e de seu promotor, e também avaliar a presença de outros promotores internos no operon pst de PA14. 


\subsection{Avaliação da funcionalidade das sequências Pho box do operon pst e da possível regulação de $\mathrm{PhoB}$ sobre o gene $p p x$ de PA14}

Para testar se as duas sequências Pho box putativas presentes no operon pst são funcionais, foi realizado um ensaio de retardo da mobilidade eletroforética (EMSA).

Como primeiro passo, foi necessário clonar a ORF de PhoB, e expressar e purificar a proteína. Para isso, $p h o B$ foi amplificado por PCR e clonado no vetor de expressão pET-28a(+). Essa construção foi eletroporada na cepa BL21 (DE3) de E. coli e foi realizado um ensaio da expressão da proteína PhoB-His em pequena escala. Testaram-se as temperaturas de crescimento de 30 e $37^{\circ} \mathrm{C}$. A separação das proteínas do extrato de células por SDS-PAGE mostrou de forma clara uma banda intensa do tamanho próximo ao esperado, de 26,6 kDa, nas culturas induzidas com IPTG em ambas as temperaturas de crescimento (Figura 22). Além disso, ensaios de solubilidade mostraram que a maior parte da proteína expressada encontrava-se na fração solúvel (dados não apresentados).

A proteína PhoB-His foi então purificada em coluna de afinidade, originando um pico intenso correspondente à espécie proteica principal das frações coletadas, assim como pequenos ombros nas laterais desse pico, principalmente nas frações finais (Figura 23a). O gel de poliacrilamida que avaliou a pureza da proteína nas frações eluídas, mostrou bandas intensas e relativamente puras nas frações 4 e 5 (Figura 23b). Essas frações foram utilizadas para o ensaio de EMSA. A proteína PhoB-His purificada foi fosforilada in vitro utilizando-se acetil fosfato como doador do grupo fosforil. Fragmentos de DNA

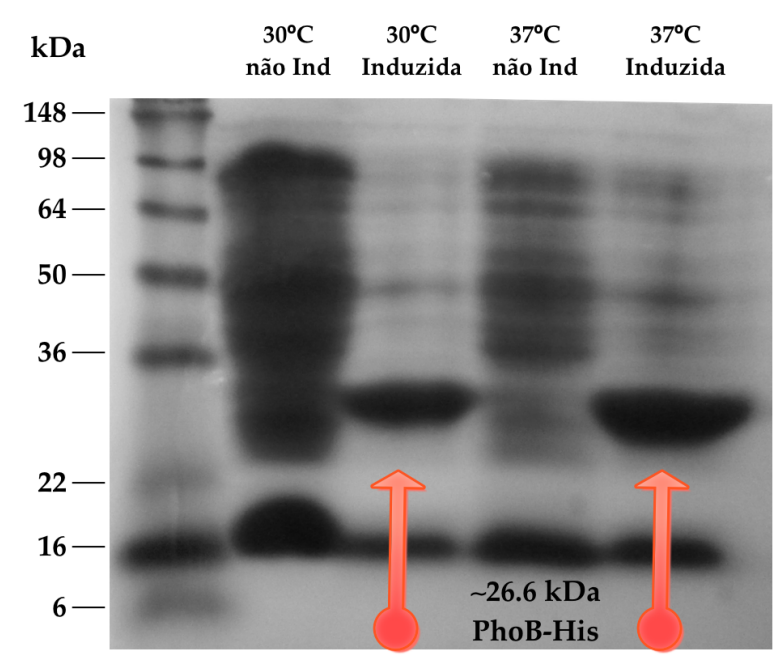

Figura 22 - Mini ensaio de indução de PhoB-His. SDS-PAGE (15\%) com os extratos de proteína das culturas de BL21 (DE3) crescidas a 30 e $37{ }^{\circ} \mathrm{C}$. As culturas induzidas foram tratadas com IPTG a uma concentração de $1 \mathrm{mM}$ por 4 horas. 


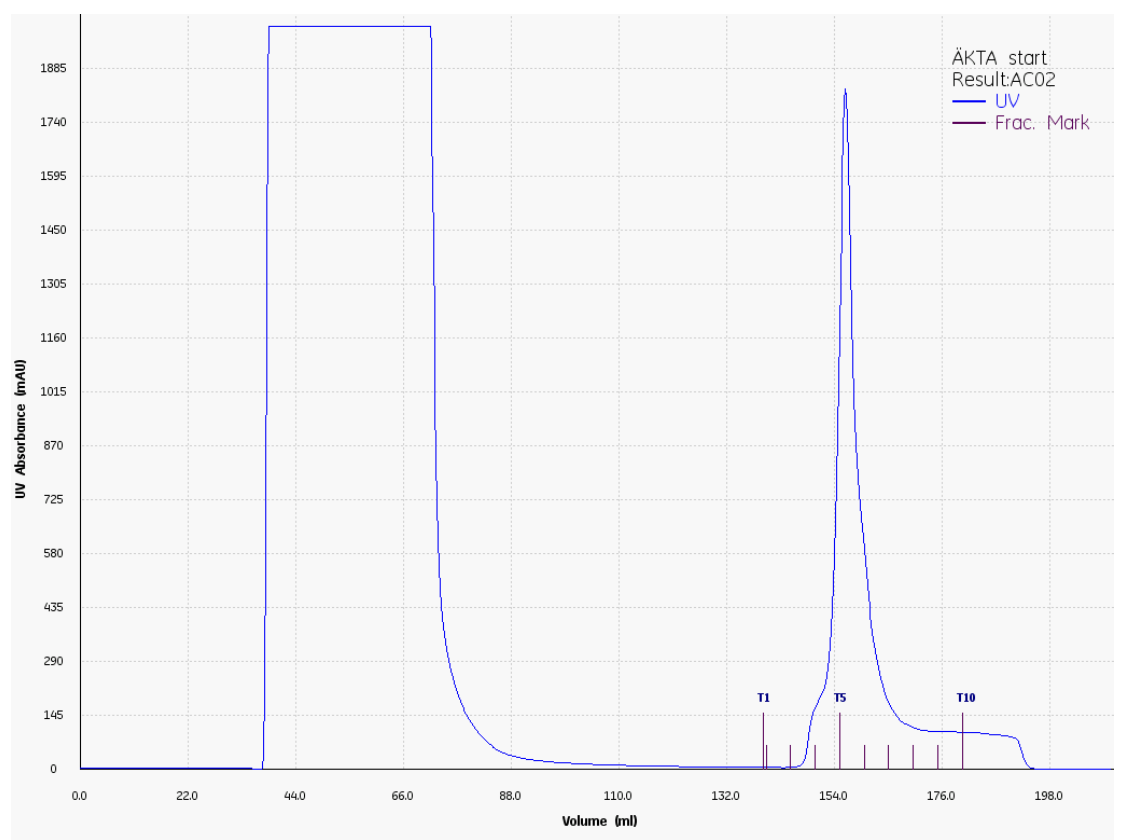

(a)

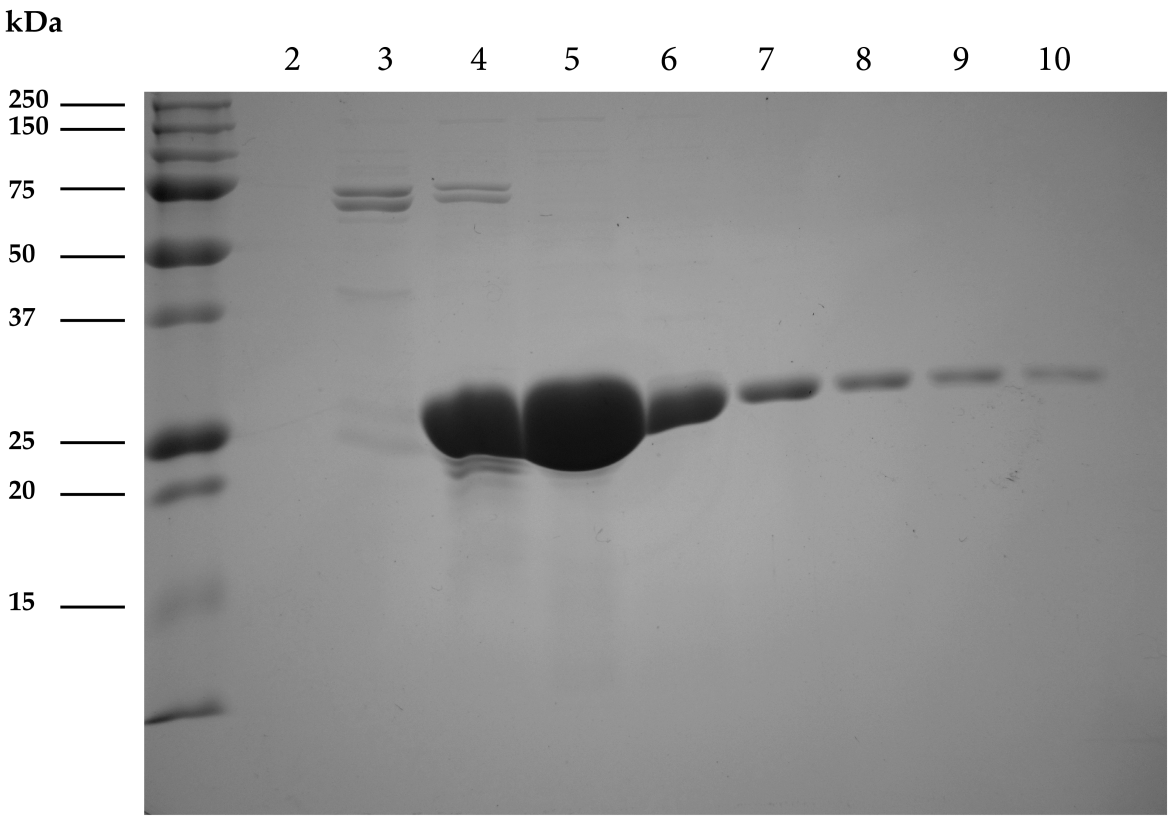

(b)

Figura 23 - Purificação de PhoB-His por cromatografia de afinidade por íons metálicos imobilizados. A coluna de afinidade carregada com $\mathrm{Ni}^{2+}$ foi equilibrada com tampão de ligação $(50 \mathrm{mM}$ de tris. $\mathrm{HCl}(\mathrm{pH} 8,0), 200 \mathrm{mM}$ de $\mathrm{NaCl}$ e $10 \mathrm{mM}$ de imidazol). Uma cultura de BL21 (DE3), cultivada a $30{ }^{\circ} \mathrm{C}$ por 4 horas em LB suplementado com $0,5 \mathrm{mM}$ de IPTG, foi lisada, clarificada e inserida na coluna de afinidade. Depois de várias lavagens com tampão de ligação, a proteína foi eluída com tampão de eluição contendo imidazol (500 mM). (a) $\mathrm{O}$ cromatograma apresentado corresponde às diferentes frações de PhoB-His eluídas da coluna. (b) Gel de poliacrilamida em condições desnaturantes (SDS-PAGE 15\%) com as frações de eluição (2-10) da purificação de PhoB-His. 
correspondentes à região regulatória de $p s t S$ e $\operatorname{de} p s t C$ foram marcados radioativamente em suas extremidades utilizando-se $\left[\gamma-{ }^{32} \mathrm{P}\right]$-ATP e a enzima PNK, incubados na presença de PhoB-P, e separados em um gel nativo, conforme descrito detalhadamente nas seções 4.15.6 e 4.15.7.

O ensaio de EMSA mostrou que PhoB interagiu in vitro com as duas sondas contendo as sequências Pho box putativas localizadas a montante dos genes pstS e pstC (Figura 24). A interação com cada sequência de DNA foi observada em todas as faixas de concentração de proteína avaliadas (i.e., 0,1-20 $\mu \mathrm{M}$ ). Considerando-se o resultado do ensaio de northern blot, no qual foi detectado um transcrito correspondente ao gene $p s t S$, esperava-se que o Pho box localizado a montante desse gene fosse completamente funcional. Contudo, não havia evidência direta sobre a funcionalidade do segundo Pho box localizado na região intergênica entre pstS e pstC. Esse resultado sugere que o operon pst de PA14 deve ser transcrito a partir de dois locais diferentes, gerando-se pelo menos dois transcritos: pstS e pstCABphoU. Interessantemente, em (BAINS et al., 2012) foi observado que o nível de expressão dos genes $p s t C$, pstA, pstB e phoU é similar, porém diferente ao nível de expressão do gene $p s t S$.

De acordo com (GALLARATO et al., 2014), deve haver um Pho box funcional a montante de $p p x$. Porém, os resultados com a fusão ${ }_{p p x} P$-lac $Z$ aqui apresentados, mostraram claramente que $p p x$ não responde à carência de Pi. Desta maneira, resolvemos testar se o Pho box putativo, sugerido por (GALLARATO et al., 2014), é funcional. A interação de PhoB-His com o Pho box putativo de $p p x$ mostrou-se muito fraca quando comparada com aquela observada para os Pho box de pstS e pstC. Além disso, PhoB-His ligou-se à sonda ppx somente quando presente em altas concentrações (i.e., $\geq 10 \mu \mathrm{M}$ ), porém, mesmo na maior concentração de PhoB-His (i.e., $20 \mu \mathrm{M}$ ), a quantidade de sonda ligada continuou sendo baixa. Isto sugere que o fraco sinal observado referente ao shift da banda de $p p x$ deve ser fruto de uma interação inespecífica de PhoB-His com o DNA.

Em conclusão, a presença de um Pho box funcional a montante de $p p x$ é improvável, dada a fraca interação entre PhoB-His e o DNA a montante de ppx. Portanto, considerando-se:

1. Os ensaios de $\beta$-galactosidase com a fusão ${ }_{p p x} P$-lac $Z$, que mostraram que $p p x$ não é induzido em carência de Pi 


\section{Sonda pstS}

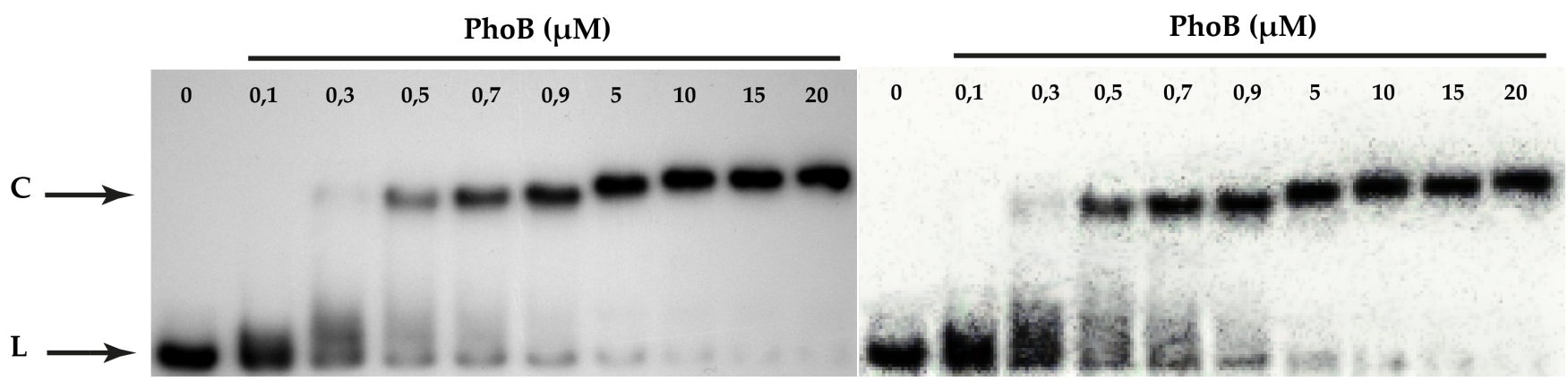

\section{Sonda pstC}

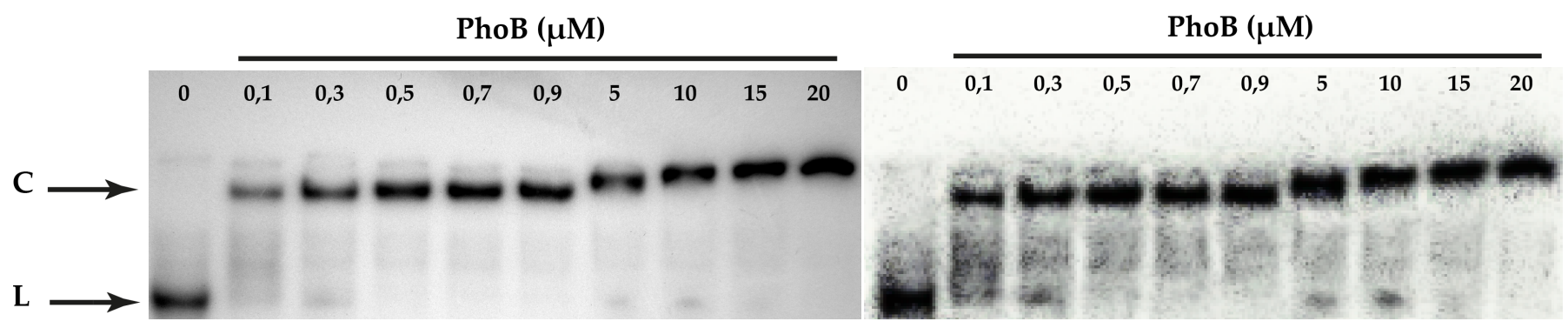

\section{Sonda $p p x$}

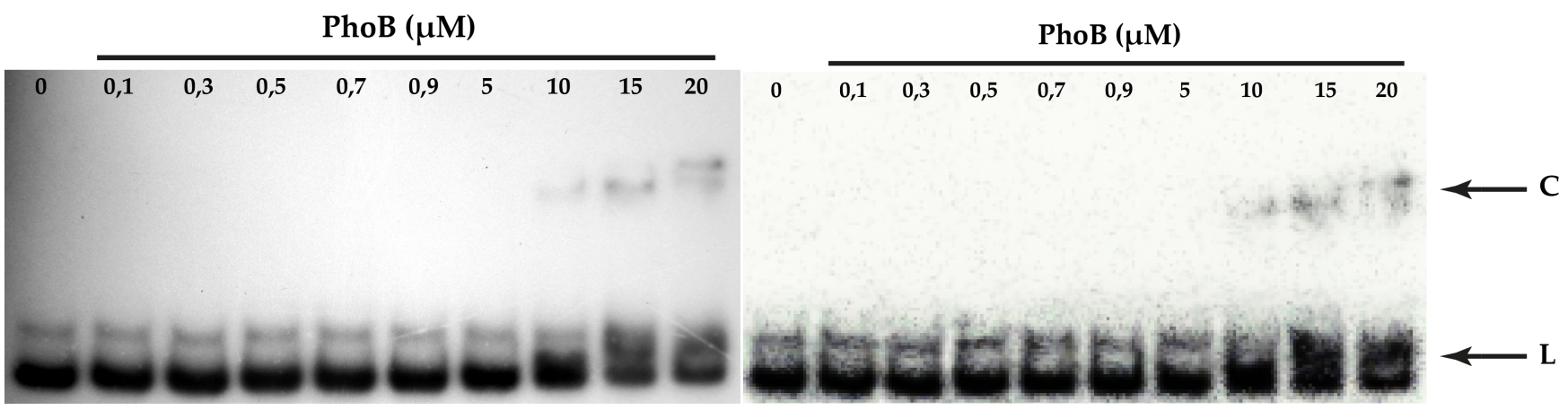

Figura 24 - Ensaio de ligação in vitro de $\mathrm{PhoB}$ nas regiões promotoras dos genes $\boldsymbol{p s t} \boldsymbol{S}, \boldsymbol{p s t} \boldsymbol{C}$ e $\boldsymbol{p} \boldsymbol{p} \boldsymbol{x}$. São apresentados os resultados dos ensaios de retardo da mobilidade eletroforética no estudo da ligação da proteína PhoB-His em três promotores de interesse. Os sítios de ligação encontram-se centrados em suas sequências Pho box putativas. Cada sonda foi incubada com $0 ; 0,1 ; 0,3$; 0,$5 ; 0,7 ; 0,9 ; 5 ; 10 ; 15$ e $20 \mu \mathrm{M}$ de PhoB-His como mostrado. O DNA livre e o complexo PhoB-His-DNA foram nomeados como L e C, respectivamente. Cada gel foi visualizado por autorradiografia (esquerda) e por análise com phosphorimager (direita). 
2. O ensaio de EMSA, que mostrou que PhoB-His interage fracamente com o suposto Pho box a montante de $p p x$

3. O acúmulo de poliP que ocorre de forma exacerbada no mutante phoU Pho constitutivo (ALMEIDA et al., 2015)

é muito provável que a suposta dependência de $p p x$ por PhoB, descrita para PAO1 (GALLARATO et al., 2014), não seja relevante para a cepa PA14. 


\section{CONCLUSÕES}

- Os genes hemB e ppk são transcritos juntamente, formando um operon.

- Os genes $p p k$ e $p p x$ são expressos a partir de promotores constitutivos, não sendo evidenciado nenhum aumento em sua expressão em condições de limitação de Pi ou de N.

- Constatou-se alterações significativas nos níveis de expressão dos genes $p p k$ e $p p x$ no mutante phoU. A inibição parcial de $p p x$, e o aumento na expressão de $p p k$ devem contribuir para o acúmulo de poliP característico da cepa $p h o U^{-}$.

- Foi detectado o transcrito pstS do operon pst. No entanto, por limitações técnicas, não foi possível determinar o padrão de transcrição completo desse operon

- Há um promotor localizado imediatamente a montante da ORF de PhoU, que não responde à disponibilidade de $\mathrm{Pi}$ no meio.

- O operon pst contém duas Pho box funcionais.

- A Pho box a montante de $p p x$ aparentemente não é funcional. 


\section{REFERÊNCIAS ${ }^{*}$}

AGUENA, M.; FERREIRA, G. M.; SPIRA, B. Stability of the pstS transcript of Escherichia coli. Archives of Microbiology, v. 191, n. 2, p. 105-112, set. 2008.

AGUENA, M.; YAGIL, E.; SPIRA, B. Transcriptional analysis of the pst operon of Escherichia coli. Molecular Genetics and Genomics, v. 268, n. 4, p. 518-524, dez. 2002.

AHN, K.; KORNBERG, A. Polyphosphate kinase from Escherichia coli. Purification and demonstration of a phosphoenzyme intermediate. Journal of Biological Chemistry, v. 265, n. 20, p. 11734-11739, 1990.

AKIYAMA, M.; CROOKE, E.; KORNBERG, A. An exopolyphosphatase of Escherichia coli. The enzyme and its $p p x$ gene in a polyphosphate operon. Journal of Biological Chemistry, v. 268, n. 1, p. 633-639, jan. 1993.

ALI, N. J.; KESSEL, D.; MILLER, R. F. Bronchopulmonary infection with Pseudomonas aeruginosa in patients infected with human immunodeficiency virus. Genitourinary Medicine, v. 71, n. 2, p. 73-77, abr. 1995.

ALLENBY, N. E. E. Post-transcriptional regulation of the Bacillus subtilis pst operon encoding a phosphate-specific ABC transporter. Microbiology, v. 150, n. 8, p. 26192628, ago. 2004.

ALMEIDA, L. G. de. Acúmulo de polifosfato e o papel do gene phoU em Pseudomonas aeruginosa. Dissertação (Mestrado) — Universidade de São Paulo, dez. 2013.

ALMEIDA, L. G. de et al. phoU inactivation in Pseudomonas aeruginosa enhances accumulation of ppGpp and polyphosphate. Applied and Environmental Microbiology, v. 81, n. 9, p. 3006-3015, maio 2015.

ALTSCHUL, S. F. et al. Basic local alignment search tool. Journal of Molecular Bio$\operatorname{logy}$, v. 215, n. 3, p. 403-410, out. 1990.

ANBA, J. et al. Nucleotide sequence of the Pseudomonas aeruginosa phoR gene, the regulatory gene for the phosphate regulon. Journal of Bacteriology, v. 172, n. 8, p. 4685-4689, ago. 1990.

AUESUKAREE, C. et al. Intracellular phosphate serves as a signal for the regulation of the PHO pathway in Saccharomyces cerevisiae. Journal of Biological Chemistry, v. 279 , n. 17 , p. $17289-17294$, abr. 2004.

AULT-RICHÉ, D. et al. Novel assay reveals multiple pathways regulating stress-induced accumulations of inorganic polyphosphate in Escherichia coli. Journal of Bacteriology, v. 180, n. 7 , p. 1841-1847, abr. 1998.

BAEK, J. H.; LEE, S. Y. Novel gene members in the Pho regulon of Escherichia coli. FEMS Microbiology Letters, v. 264, n. 1, p. 104-109, nov. 2006.

BAINS, M.; FERNÁNDEZ, L.; HANCOCK, R. E. W. Phosphate starvation promotes swarming motility and cytotoxicity of Pseudomonas aeruginosa. Applied and Environmental Microbiology, v. 78, n. 18, p. 6762-6768, set. 2012. 
BECHER, A.; SCHWEIZER, H. P. Integration-proficient Pseudomonas aeruginosa vectors for isolation of single-copy chromosomal lacZ and lux gene fusions. BioTechniques, v. 29 , n. 5, p. 948-952, nov. 2000.

BENDIG, J. W. et al. Two neutropenic patients with multiple resistant Pseudomonas aeruginosa septicaemia treated with ciprofloxacin. Journal of the Royal Society of Medicine, v. 80, n. 5, p. 316-317, maio 1987.

BLATTNER, F. R. et al. The complete genome sequence of Escherichia coli K-12. Science, v. 277, n. 5331, p. 1453-1462, set. 1997.

BOLESCH, D. G.; KEASLING, J. D. Polyphosphate binding and chain length recognition of Escherichia coli exopolyphosphatase. Journal of Biological Chemistry, v. 275, n. 43 , p. 33814-33819, out. 2000.

CAMPILLO, M. C. D.; ZEE, S. E. A. T. M. V. D.; TORRENT, J. Modelling long-term phosphorus leaching and changes in phosphorus fertility in excessively fertilized acid sandy soils. European Journal of Soil Science, v. 50, n. 3, p. 391-399, set. 1999.

CARMANY, D. O.; HOLLINGSWORTH, K.; MCCLEARY, W. R. Genetic and biochemical studies of phosphatase activity of PhoR. Journal of Bacteriology, v. 185, n. 3, p. $1112-1115$, fev. 2003.

CHIN, J. C.; WATTS, J. E. Biological properties of phospholipase C purified from a fleecerot isolate of Pseudomonas aeruginosa. Microbiology, v. 134, n. 9, p. 2567-2575, set. 1988 .

CHOI, K.-H.; KUMAR, A.; SCHWEIZER, H. P. A 10-min method for preparation of highly electrocompetent Pseudomonas aeruginosa cells: Application for DNA fragment transfer between chromosomes and plasmid transformation. Journal of Microbiological Methods, v. 64, n. 3, p. 391-397, mar. 2006.

CHRISTENSSON, M.; BLACKALL, L. L.; WELANDER, T. Metabolic transformations and characterisation of the sludge community in an enhanced biological phosphorus removal system. Applied Microbiology and Biotechnology, v. 49, n. 2, p. 226-234, fev. 1998.

CHURCH, D. et al. Burn wound infections. Clinical Microbiology Reviews, v. 19, n. 2, p. 403-434, abr. 2006.

DIEN, S. J. V.; KEASLING, J. D. Control of polyphosphate metabolism in genetically engineered Escherichia coli. Enzyme and Microbial Technology, v. 24, n. 1, p. 21-25, 1999.

DURFEE, T. et al. The complete genome sequence of Escherichia coli DH10B: insights into the biology of a laboratory workhorse. Journal of Bacteriology, v. 190, n. 7, p. 2597-2606, abr. 2008.

FILLOUX, A. et al. Phosphate regulation in Pseudomonas aeruginosa: cloning of the alkaline phosphatase gene and identification of $p h o B$-and $p h o R$-like genes. Molecular \& General Genetics, v. 212, n. 3, p. 510-513, 1988. 
FISCHER, R. J. et al. Transcription of the pst Operon of Clostridium acetobutylicum Is Dependent on Phosphate Concentration and pH. Journal of Bacteriology, v. 188, n. 15 , p. 5469-5478, jul. 2006.

FITZSIMMONS, S. C. The changing epidemiology of cystic fibrosis. The Journal of Pediatrics, v. 122, n. 1, p. 1-9, 1993.

FRANKENBERG, N. et al. Cloning, mapping and functional characterization of the hemB gene of Pseudomonas aeruginosa, which encodes a magnesium-dependent 5-aminolevulinic acid dehydratase. Molecular \& General Genetics, v. 257, n. 4, p. 485-489, fev. 1998.

GALLARATO, L. A. et al. Exopolyphosphatase of Pseudomonas aeruginosa is essential for the production of virulence factors, and its expression is controlled by NtrC and PhoB acting at two interspaced promoters. Microbiology, v. 160, n. Pt 2, p. 406-417, fev. 2014 .

GARDNER, S. G. et al. The PhoU protein from Escherichia coli interacts with PhoR, PstB, and metals to form a phosphate-signaling complex at the membrane. Journal of Bacteriology, v. 196, n. 9, p. 1741-1752, maio 2014.

GAY, P. et al. Positive selection procedure for entrapment of insertion sequence elements in gram-negative bacteria. Journal of Bacteriology, v. 164, n. 2, p. 918-921, nov. 1985.

GEISSDÖRFER, W. W.; RATAJCZAK, A. A.; HILLEN, W. W. Transcription of $p p k$ from Acinetobacter sp. strain ADP1, encoding a putative polyphosphate kinase, is induced by phosphate starvation. Applied and Environmental Microbiology, v. 64, n. 3, p. 896-901, mar. 1998.

GRAY, G. L.; BERKA, R. M.; VASIL, M. L. Phospholipase C regulatory mutation of Pseudomonas aeruginosa that results in constitutive synthesis of several phosphaterepressible proteins. Journal of Bacteriology, v. 150, n. 3, p. 1221-1226, jun. 1982.

GRAY, M. J.; JAKOB, U. Oxidative stress protection by polyphosphate - new roles for an old player. Current Opinion in Microbiology, v. 24, p. 1-6, abr. 2015.

GRAY, M. J. et al. Polyphosphate is a primordial chaperone. Molecular Cell, v. 53, n. 5, p. 689-699, mar. 2014.

GREEN, S. K. et al. Agricultural plants and soil as a reservoir for Pseudomonas aeruginosa. Applied Microbiology, v. 28, n. 6, p. 987-991, dez. 1974.

GRIFFITH, K. L.; WOLF JR., R. E. Measuring $\beta$-galactosidase activity in bacteria: cell growth, permeabilization, and enzyme assays in 96-well arrays. Biochemical and Biophysical Research Communications, v. 290, n. 1, p. 397-402, jan. 2002.

GRILLO-PUERTAS, M. et al. Copper tolerance mediated by polyphosphate degradation and low-affinity inorganic phosphate transport system in Escherichia coli. BMC Microbiology, v. 14, n. 1, p. 72, mar. 2014.

HAN, J. S. et al. PhoB-dependent transcriptional activation of the $i c i A$ gene during starvation for phosphate in Escherichia coli. Molecular \& General Genetics, v. 262, n. 3, p. 448-452, out. 1999. 
HANCOCK, R. E. R.; POOLE, K.; BENZ, R. Outer membrane protein P of Pseudomonas aeruginosa regulation by phosphate deficiency and formation of small anion-specific channels in lipid bilayer membranes. Journal of Bacteriology, v. 150, n. 2, p. 730-738, 1982.

HANCOCK, R. E. R.; RAFFLE, V. J. V.; NICAS, T. I. T. Involvement of the outer membrane in gentamicin and streptomycin uptake and killing in Pseudomonas aeruginosa. Antimicrobial Agents and Chemotherapy, v. 19, n. 5, p. 777-785, maio 1981.

HARDOYO et al. Production and release of polyphosphate by a genetically engineered strain of Escherichia coli. Applied and Environmental Microbiology, v. 60, n. 10, p. 3485-3490, out. 1994.

HIGGINS, C. F. et al. A novel intercistronic regulatory element of prokaryotic operons. Nature, v. 298, n. 5876, p. 760-762, ago. 1982.

HIRAISHI, A.; MORISHIMA, Y. Capacity for polyphosphate accumulation of predominant bacteria in activated-sludge showing enhanced phosphate removal. Journal of Fermentation and Bioengineering, v. 69, n. 6, p. 368-371, 1990.

HOANG, T. T. et al. A broad-host-range Flp-FRT recombination system for site-specific excision of chromosomally-located DNA sequences: application for isolation of unmarked Pseudomonas aeruginosa mutants. Gene, v. 212, n. 1, p. 77-86, maio 1998.

HOCH, J. A.; SILHAVY, T. J. Two-component Signal Transduction. Herndon, Virginia, U.S.A: ASM Press, 1995. (American Society Mic Series).

HORAZDOVSKY, B. F. B.; HOGG, R. W. R. High-affinity L-arabinose transport operon. Gene product expression and mRNAs. Journal of Molecular Biology, v. 197, n. 1, p. 27-35, set. 1987.

HSIEH, Y.-J.; WANNER, B. L. Global regulation by the seven-component Pi signaling system. Current Opinion in Microbiology, p. 1-6, fev. 2010.

ISHIGE, K. et al. The polyphosphate kinase gene of Pseudomonas aeruginosa. DNA Research, v. 5, n. 3, p. 157-162, jun. 1998.

ISHIGE, K.; ZHANG, H.; KORNBERG, A. Polyphosphate kinase (PPK2), a potent, polyphosphate-driven generator of GTP. Proceedings of the National Academy of Sciences of the United States of America, v. 99, n. 26, p. 16684-16688, dez. 2002.

JUNG, S. Two types of transcriptional controls on polyphosphate kinase (PPK) gene promoters in different bacteria. Tese (Doutorado) - Purdue University, 2008.

JUNG, S. et al. Effect of purine limitation caused by an amidophosphoribosyl transferase (purF) mutation on polyphosphate kinase 1 ( $p p k 1)$ gene expression. Genes \& Genomics, v. 34, n. 1, p. 27-34, jan. 2012.

KATO, J. et al. Genetic improvement of Escherichia coli for enhanced biological removal of phosphate from wastewater. Applied and Environmental Microbiology, v. 59, n. 11, p. 3744-3749, nov. 1993. 
KATO, J. J. et al. Cloning and characterization of a Pseudomonas aeruginosa gene involved in the negative regulation of phosphate taxis. Journal of Bacteriology, v. 176, n. 18 , p. $5874-5877$, set. 1994.

Cloning, sequence and characterization of the polyphosphate kinase-encoding gene $\overline{(p p k)}$ of Klebsiella aerogenes. Gene, v. 137, n. 2, p. 237-242, dez. 1993.

KIELHOFNER, M. et al. Life-threatening Pseudomonas aeruginosa infections in patients with human immunodeficiency virus infection. Clinical Infectious Diseases, v. 14, n. 2, p. 403-411, fev. 1992.

KIM, H. Y. et al. Alginate, inorganic polyphosphate, GTP and ppGpp synthesis coregulated in Pseudomonas aeruginosa: implications for stationary phase survival and synthesis of RNA/DNA precursors. Molecular Microbiology, v. 27, n. 4, p. 717-725, fev. 1998.

KIRCHMAN, D. L. The uptake of inorganic nutrients by heterotrophic bacteria. Microbial Ecology, v. 28, n. 2, p. 255-271, set. 1994.

KORNBERG, A.; KORNBERG, S. R.; SIMMS, E. S. Metaphosphate synthesis by an enzyme from Escherichia coli. Biochimica Et Biophysica Acta, v. 20, n. 1, p. 215$227,1956$.

KORNBERG, S. R. Adenosine triphosphate synthesis from polyphosphate by an enzyme from Escherichia coli. Biochimica Et Biophysica Acta, v. 26, n. 2, p. 294-300, 1957.

KORTELAND, J.; DEGRAAFF, P.; LUGTENBERG, B. PhoE protein pores in the outermembrane of Escherichia coli K-12 not only have a preference for Pi and Pi-containing solutes but are general anion-preferring channels. Biochimica Et Biophysica Acta, v. 778 , n. 2 , p. $311-316,1984$.

KORTELAnD, J.; TOMMASSEN, J.; LUGTENBERG, B. PhoE protein pore of the outer membrane of Escherichia coli K12 is a particularly efficient channel for organic and inorganic phosphate. Biochimica et Biophysica Acta - Biomembranes, v. 690, n. 2, p. 282-289, 1982.

KULAEV, I.; VAGABOV, V.; KULAKOVSKAYA, T. The Biochemistry of Inorganic Polyphosphates. Southern Gate Chichester, West Sussex, England: Wiley, 2005. (Wiley InterScience online books).

KURIOKA, S.; LIU, P. V. Effect of the hemolysin of Pseudomonas aeruginosa on phosphatides and on phospholipase $\mathrm{C}$ activity. Journal of Bacteriology, v. 93, n. 2, p. 670-674, fev. 1967.

KURODA, A.; KORNBERG, A. Polyphosphate kinase as a nucleoside diphosphate kinase in Escherichia coli and Pseudomonas aeruginosa. Proceedings of the National Academy of Sciences of the United States of America, v. 94, n. 2, p. 439-442, jan. 1997.

KURODA, A. et al. Guanosine tetra- and pentaphosphate promote accumulation of inorganic polyphosphate in Escherichia coli. Journal of Biological Chemistry, v. 272, n. 34, p. 21240-21243, ago. 1997. 
Inorganic polyphosphate kinase is required to stimulate protein degradation and for adaptation to amino acid starvation in Escherichia coli. Proceedings of the National Academy of Sciences of the United States of America, v. 96, n. 25, p. 14264-14269, dez. 1999.

LEE, D. G. et al. Genomic analysis reveals that Pseudomonas aeruginosa virulence is combinatorial. Genome biology, v. 7, n. 10, p. R90, 2006.

LEE, K. et al. Overexpression of outer membrane protein OprT and increase of membrane permeability in phoU mutant of toluene-tolerant bacterium Pseudomonas putida GM730. The Journal of Microbiology, v. 47, n. 5, p. 557-562, out. 2009.

LI, Y.; ZHANG, Y. PhoU is a persistence switch involved in persister formation and tolerance to multiple antibiotics and stresses in Escherichia coli. Antimicrobial Agents and Chemotherapy, v. 51, n. 6, p. 2092-2099, maio 2007.

LIN-LIN, B. et al. Phosphorus accumulation by bacteria isolated from a continuous-flow two-sludge system. Journal of Environmental Sciences, v. 19, n. 4, p. 391-395, 2007.

LIU, P. V. The roles of various fractions of Pseudomonas aeruginosa in its pathogenesis: II. Effects of lecithinase and protease. The Journal of Infectious Diseases, v. 116, n. 1 , p. $112-116$, fev. 1966.

MAKINO, K. et al. Molecular analysis of the cryptic and functional phn operons for phosphonate use in Escherichia coli K-12. Journal of Bacteriology, v. 173, n. 8, p. 2665-2672, abr. 1991.

Nucleotide sequence of the $p h o R$ gene, a regulatory gene for the phosphate regulon of Escherichia coli. Journal of Molecular Biology, v. 192, n. 3, p. 549-556, jan. 1986.

Regulation of the phosphate regulon of Escherichia coli. Activation of pstS transcription by PhoB protein in vitro. Journal of Molecular Biology, v. 203, n. 1, p. 85-95, set. 1988.

MAKINO, K. K. et al. Signal transduction in the phosphate regulon of Escherichia coli involves phosphotransfer between PhoR and PhoB proteins. Journal of Molecular Biology, v. 210, n. 3, p. 551-559, dez. 1989.

MCCLEARY, W. R. The activation of PhoB by acetylphosphate. Molecular Microbiology, v. 20, n. 6, p. 1155-1163, jun. 1996.

MCCLEARY, W. R.; STOCK, J. B. Acetyl phosphate and the activation of twocomponent response regulators. Journal of Biological Chemistry, v. 269, n. 50, p. 31567-31572, dez. 1994.

MILLER, J. H. A Short Course in Bacterial Genetics: A Laboratory Manual and Handbook for Escherichia Coli and Related Bacteria. Los Angeles, California, U.S.A: Cold Spring Harbor Laboratory Press, 1992.

MIYAKE, T. et al. The gene for an exopolyphosphatase of Pseudomonas aeruginosa. DNA Research, v. 6, n. 2, p. 103-108, abr. 1999.

MONDS, R. D. et al. Conservation of the Pho regulon in Pseudomonas fluorescens Pf0-1. Applied and Environmental Microbiology, v. 72, n. 3, p. 1910-1924, mar. 2006. 
MOROHOSHI, T. et al. Accumulation of inorganic polyphosphate in phoU mutants of Escherichia coli and Synechocystis sp. strain PCC6803. Applied and Environmental Microbiology, v. 68, n. 8, p. 4107-4110, 2002.

MUDA, M.; RAO, N. N.; TORRIANI, A. Role of PhoU in phosphate transport and alkaline phosphatase regulation. Journal of Bacteriology, v. 174, n. 24, p. 8057-8064, dez. 1992.

MULLER, M. Pyocyanin induces oxidative stress in human endothelial cells and modulates the glutathione redox cycle. Free Radical Biology and Medicine, v. 33, n. 11, p. 1527-1533, dez. 2002.

MURATA, K. et al. Polyphosphate kinase: distribution, some properties and its application as an ATP regeneration system (microbiology \& fermentation industry). Agricultural and Biological Chemistry, v. 52, n. 6, p. 1471-1477, jun. 1988.

NAKATA, A.; AMEMURA, M.; SHINAGAWA, H. Regulation of the phosphate regulon in Escherichia coli K-12: regulation of the negative regulatory gene phoU and identification of the gene product. Journal of Bacteriology, v. 159, n. 3, p. 979-985, set. 1984.

NEIDHARDT, F. C. Escherichia coli and Salmonella typhimurium: Cellular and Molecular Biology 2. Washington D.C., U.S.A: American Society for Microbiology, 1996.

NIKATA, T. et al. Molecular analysis of the phosphate-specific transport (pst) operon of Pseudomonas aeruginosa. Molecular \& General Genetics, v. 250, n. 6, p. 692-698, abr. 1996.

OHTAKE, H. et al. Genetic approach to enhanced biological phosphorus removal. Water Science and Technology, v. 30, n. 6, p. 185-192, 1994.

PODBIELSKI, A. et al. Molecular characterization of group A streptococcal (GAS) oligopeptide permease (Opp) and its effect on cysteine protease production. Molecular Microbiology, v. 21, n. 5, p. 1087-1099, set. 1996.

RAHME, L. G. et al. Common virulence factors for bacterial pathogenicity in plants and animals. Science, v. 268, n. 5219, p. 1899-1902, jun. 1995.

RAO, N. N.; KORNBERG, A. Inorganic polyphosphate supports resistance and survival of stationary-phase Escherichia coli. Journal of Bacteriology, v. 178, n. 5, p. 13941400, mar. 1996.

RAO, N. N.; LIU, S.; KORNBERG, A. Inorganic polyphosphate in Escherichia coli: the phosphate regulon and the stringent response. Journal of Bacteriology, v. 180, n. 8, p. 2186-2193, abr. 1998.

RAO, N. N.; ROBERTS, M. F.; TORRIANI, A. Amount and chain length of polyphosphates in Escherichia coli depend on cell growth conditions. Journal of Bacteriology, v. 162, n. 1, p. 242-247, abr. 1985.

RASHID, M. H.; KORNBERG, A. Inorganic polyphosphate is needed for swimming, swarming, and twitching motilities of Pseudomonas aeruginosa. Proceedings of the National Academy of Sciences of the United States of America, v. 97, n. 9, p. 4885-4890, abr. 2000. 
RASHID, M. H.; RAO, N. N.; KORNBERG, A. Inorganic polyphosphate is required for motility of bacterial pathogens. Journal of Bacteriology, v. 182, n. 1, p. 225-227, jan. 2000 .

RASHID, M. H. et al. Polyphosphate kinase is essential for biofilm development, quorum sensing, and virulence of Pseudomonas aeruginosa. Proceedings of the National Academy of Sciences of the United States of America, v. 97, n. 17, p. 9636-9641, ago. 2000.

REHM, B. H. A. Pseudomonas: Model Organism, Pathogen, Cell Factory. Germany: Wiley, 2008.

ROBINSON, N. A.; WOOD, H. G. Polyphosphate kinase from Propionibacterium shermanii. Demonstration that the synthesis and utilization of polyphosphate is by a processive mechanism. Journal of Biological Chemistry, v. 261, n. 10, p. 4481-4485, abr. 1986.

ROBInSON, N. A. N.; CLARK, J. E. J.; WOOD, H. G. H. Polyphosphate kinase from Propionibacterium shermanii. Demonstration that polyphosphates are primers and determination of the size of the synthesized polyphosphate. Journal of Biological Chemistry, v. 262, n. 11, p. 5216-5222, abr. 1987.

SAMBROOK, J.; RUSSELL, D. W. Molecular Cloning: A Laboratory Manual. Cold Spring Harbor, New York, U.S.A: Cold Spring Harbor Laboratory Press, 2001.

SCHWEIZER, H.; BOOS, W. Characterization of the ugp region containing the genes for the phoB dependent sn-glycerol-3-phosphate transport system of Escherichia coli. Molecular \& General Genetics, v. 197, n. 1, p. 161-168, 1984.

SHI, W.; ZHANG, Y. PhoY2 but not PhoY1 is the PhoU homologue involved in persisters in Mycobacterium tuberculosis. Journal of Antimicrobial Chemotherapy, v. 65, n. 6, p. 1237-1242, jun. 2010.

SHIBA, T. et al. Inorganic polyphosphate and the induction of rpoS expression. Proceedings of the National Academy of Sciences of the United States of America, v. 94 , n. 21 , p. 11210-11215, out. 1997.

SILBY, M. W.; NICOLL, J. S.; LEVY, S. B. Requirement of polyphosphate by Pseudomonas fluorescens Pf0-1 for competitive fitness and heat tolerance in laboratory media and sterile soil. Applied and Environmental Microbiology, v. 75, n. 12, p. 3872-3881, jun. 2009.

SIMON, R.; PRIEFER, U.; PÜHLER, A. A broad host range mobilization system for in vivo genetic engineering: transposon mutagenesis in gram negative bacteria. Nature Biotechnology, v. 1, n. 9, p. 784-791, nov. 1983.

SPIRA, B. et al. Alternative promoters in the pst operon of Escherichia coli. Molecular Genetics and Genomics, v. 284, n. 6, p. 489-498, out. 2010.

SPIRA, B. B.; SILBERSTEIN, N. N.; YAGIL, E. E. Guanosine 3',5'-bispyrophosphate (ppGpp) synthesis in cells of Escherichia coli starved for Pi. Journal of Bacteriology, v. 177, n. 14, p. 4053-4058, jul. 1995. 
STEED, P. M.; WANNER, B. L. Use of the rep technique for allele replacement to construct mutants with deletions of the pstSCAB-phoU operon: evidence of a new role for the PhoU protein in the phosphate regulon. Journal of Bacteriology, v. 175, n. 21, p. 6797-6809, nov. 1993.

STINSON, M. W.; HAYDEN, C. Secretion of phospholipase C by Pseudomonas aeruginosa. Infection and Immunity, v. 25, n. 2, p. 558-564, ago. 1979.

STOVER, C. K. et al. Complete genome sequence of Pseudomonas aeruginosa PAO1, an opportunistic pathogen. Nature, v. 406, n. 6799, p. 959-964, 2000.

STREICHAN, M.; GOLECKI, J. R.; SCHöN, G. Polyphosphate-accumulating bacteria from sewage plants with different proceses for biological phosphorus removal. FEMS Microbiology Letters, v. 73, n. 2, p. 113-124, 1990.

STREIT, S. et al. Northern blot analysis for detection and quantification of RNA in pancreatic cancer cells and tissues. Nature Protocols, v. 4, n. 1, p. 37-43, 2009.

STUDIER, F. W.; MOFFATT, B. A. Use of bacteriophage T7 RNA polymerase to direct selective high-level expression of cloned genes. Journal of Molecular Biology, v. 189, n. 1, p. 113-130, maio 1986.

TORRIANI, A. Influence of inorganic phosphate in the formation of phosphatases by Escherichia coli. Biochimica Et Biophysica Acta, v. 38, p. 460-469, mar. 1960.

TORRIANI-GORINI, A.; YAGIL, E.; SILVER, S. Phosphate in Microorganisms: Cellular and Molecular Biology. Washington D.C., U.S.A: ASM Press, 1994.

TURNER, B. L.; FROSSARD, E.; BALDWIN, D. S. Organic Phosphorus in the Environment. Cambridge, MA, U.S.A: CABI Pub., 2005.

VEEN, H. W. van et al. Generation of a proton motive force by the excretion of metalphosphate in the polyphosphate-accumulating Acinetobacter johnsonii strain 210A. Journal of Biological Chemistry, v. 269, n. 47, p. 29509-29514, nov. 1994.

WACKETT, L. P. et al. Involvement of the phosphate regulon and the psiD locus in carbon-phosphorus lyase activity of Escherichia coli K-12. Journal of Bacteriology, v. 169 , n. 4 , p. $1753-1756$, abr. 1987.

WANG, C. et al. PhoY2 of Mycobacteria is required for metabolic homeostasis and stress response. Journal of Bacteriology, v. 195, n. 2, p. 243-252, jan. 2013.

WENNER, N. et al. NrsZ: a novel, processed, nitrogen-dependent, small non-coding RNA that regulates Pseudomonas aeruginosa PAO1 virulence. Environmental Microbiology, v. 16, n. 4, p. 1053-1068, out. 2013.

WENTZEL, M. C. et al. Metabolic behavior of Acinetobacter spp in enhanced biological phosphorus removal -a biochemical-model. Water SA, v. 12, n. 4, p. 209-224, out. 1986.

WHITE, A. K.; METCALF, W. W. Microbial metabolism of reduced phosphorus compounds. Annual Review of Microbiology, v. 61, n. 1, p. 379-400, out. 2007. 
WU, H. H. et al. Cloning and characterization of Pseudomonas putida genes encoding the phosphate-specific transport system. Journal of Bioscience and Bioengineering, v. 87, n. 3, p. 273-279, jan. 1999.

YANG, K.; WANG, M.; METCALF, W. W. Uptake of Glycerol-2-Phosphate via the ugpEncoded Transporter in Escherichia coli K-12. Journal of Bacteriology, v. 191, n. 14, p. 4667-4670, jun. 2009.

YE, J. et al. Primer-BLAST: a tool to design target-specific primers for polymerase chain reaction. BMC Bioinformatics, v. 13, p. 134-145, 2012.

YEOMAN, S. et al. The removal of phosphorus during wastewater treatment: a review. Environmental Pollution, v. 49, n. 3, p. 183-233, jan. 1988.

ZABORIN, A. et al. Red death in Caenorhabditis elegans caused by Pseudomonas aeruginosa PAO1. Proceedings of the National Academy of Sciences, v. 106, n. 15, p. 6327-6332, abr. 2009.

ZAGO, A. A.; CHUGAnI, S. S.; CHAKRABARTY, A. M. A. Cloning and characterization of polyphosphate kinase and exopolyphosphatase genes from Pseudomonas aeruginosa 8830. Applied and Environmental Microbiology, v. 65, n. 5, p. 2065-2071, maio 1999.

ZHANG, H.; ISHIGE, K.; KORNBERG, A. A polyphosphate kinase (PPK2) widely conserved in bacteria. Proceedings of the National Academy of Sciences of the United States of America, v. 99, n. 26, p. 16678-16683, dez. 2002.

ZHANG, X.; BREMER, H. Control of the Escherichia coli rrnB P1 promoter strength by ppGpp. Journal of Biological Chemistry, v. 270, n. 19, p. 11181-11189, maio 1995.

ZUKER, M. Mfold web server for nucleic acid folding and hybridization prediction. Nucleic Acids Research, v. 31, n. 13, p. 3406-3415, jul. 2003. 


\section{Anexos}




\section{ANEXO A - AVALIAÇÃO DA FAIXA DE LINEARIDADE DO ESPECTROFOTÔMETRO DE MICROPLACAS EPOCH ${ }^{\mathrm{TM}}$}

Técnicas de análises química que utilizam a luz como ferramenta para a determinação de concentrações químicas são amplamente empregadas. Nessas análises, o parâmetro mais indicado para ser empregado é absorbância, dado que, de acordo com a lei de Beer, ela é diretamente proporcional à concentração da espécie analisada. Contudo, essa relação apresenta desvios do modelo ideal, por razões químicas e técnicas, valendo apenas para soluções diluídas. Dessa forma, em qualquer experimento e equipamento utilizados para relacionar a absorbância com a concentração de uma espécie determinada, a faixa de linearidade desses dois parâmetros sempre deve ser tomada em consideração.

De acordo com as informações fornecidas pelo fabricante, o espectrofotômetro de microplacas Epoch ${ }^{\mathrm{TM}}$ possui uma linearidade nas faixas de absorbância de 0 a 2,5. Apesar disso, essa faixa de linearidade foi avaliada experimentalmente. Nessa avaliação, foram utilizados os comprimentos de onda empregados nos ensaios de $\beta$-galactosidase: 600 e 420 nm.

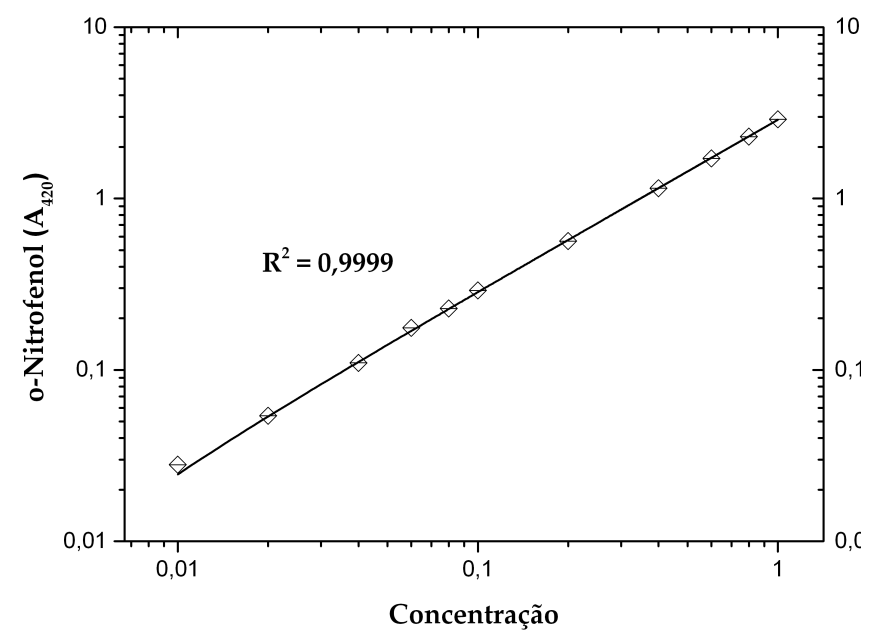

(a) Faixa de linearidade avaliada no comprimento de onda de $420 \mathrm{~nm}$.

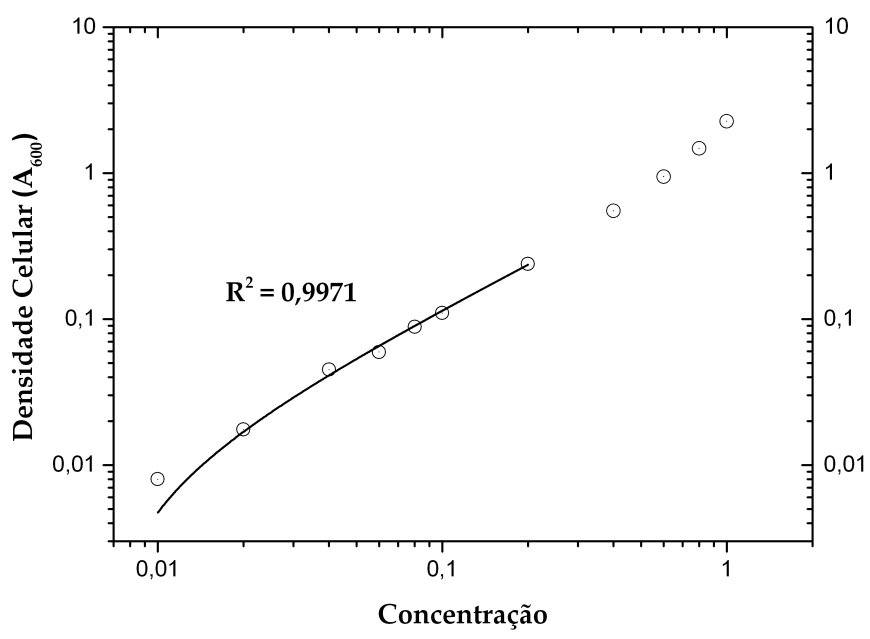

(b) Faixa de linearidade avaliada no comprimento de onda de $600 \mathrm{~nm}$.

Figura 25 - Determinação da faixa de linearidade do espectrofotômetro de microplacas Epoch $^{\mathrm{TM}}$ nos comprimentos de onda de 420 e $600 \mathrm{~nm}$. Foram preparadas diluiçoes seriadas a partir de uma solução de ONP e de uma cultura de PA14 crescida overnight em meio LB. Os valores de $\mathrm{DO}_{420} \mathrm{e}$ de $\mathrm{DO}_{600}$ foram então determinados no espectrofotômetro de placas.

Como observado na Figura 25, existe uma relação linear entre a $\mathrm{DO}_{420}$ e a concentração de o-nitrofenol em toda a faixa de absorbância avaliada, ou seja, até uma $\mathrm{DO}_{420}$ 
de aproximadamente 3,0. Essa linearidade, curiosamente, encontra-se em uma faixa mais ampla que a especificada pelo fabricante. Entretanto, a relação linear entre a $\mathrm{DO}_{600}$ e a densidade celular foi bem mais estreita, sendo $<0,25$. Portanto, nas leituras espectrofotométricas feitas no leitor de microplacas, sempre que necessário, as amostras foram diluídas para trabalhar nas faixas de linearidade descritas anteriormente: $\mathrm{DO}_{420}<3 \mathrm{e}$ $\mathrm{DO}_{600}<0,25$.

Em espectrofotometria "vertical", em que as amostras contidas em uma microplaca são atravessadas de maneira vertical pelo feixe de luz, o caminho óptico da luz é definido pelo volume da amostra no poço. Assim sendo, volumes ligeiramente diferentes em cada poço, devido a erros inerentes à pipetagem, podem gerar caminhos ópticos diferentes por cada amostra. Isso poderia acarretar erros nas absorbâncias reportadas pelo equipamento. Em consequência, a opção de correção automática do caminho óptico no leitor de microplacas foi usada em todas as leituras espectrofotométricas. Nessa correção, os valores de absorbância de cada amostra são normalizados pelo equipamento a um valor de caminho óptico de $1 \mathrm{~cm}$. Além de tudo, essa correção também faz possível a comparação de dados de $\beta$-galactosidase obtidos pelo ensaio clássico, que emprega um espectrofotômetro com cubeta de caminho óptico padrão de $1 \mathrm{~cm}$, com os dados obtidos em microplaca de 96 poços. 


\section{ANEXO B - COMPARAÇÃO DO CRESCIMENTO DE CULTURAS DE PA14 EM TUBO DE ENSAIO E EM MICROPLACA DE 24 POÇOS DE 2,2 ML}

O crescimento de PA14 em microplacas poderia gerar condições de crescimento subótimas devido a uma possível baixa oxigenação. Para avaliar essa possibilidade, culturas de PA14 foram cultivas em tubo de ensaio e em microplaca de 24 poços.

Como observado na Figura 26 a taxa de crescimento e o rendimento celular das culturas crescidas tanto em tubo de ensaio como em microplaca de 24 poços foi o mesmo nas condições testadas. Dessa forma, todas as culturas avaliadas por ensaios de $\beta$-galactosidase foram crescidas em placas de 24 poços de $2,2 \mathrm{ml}$.

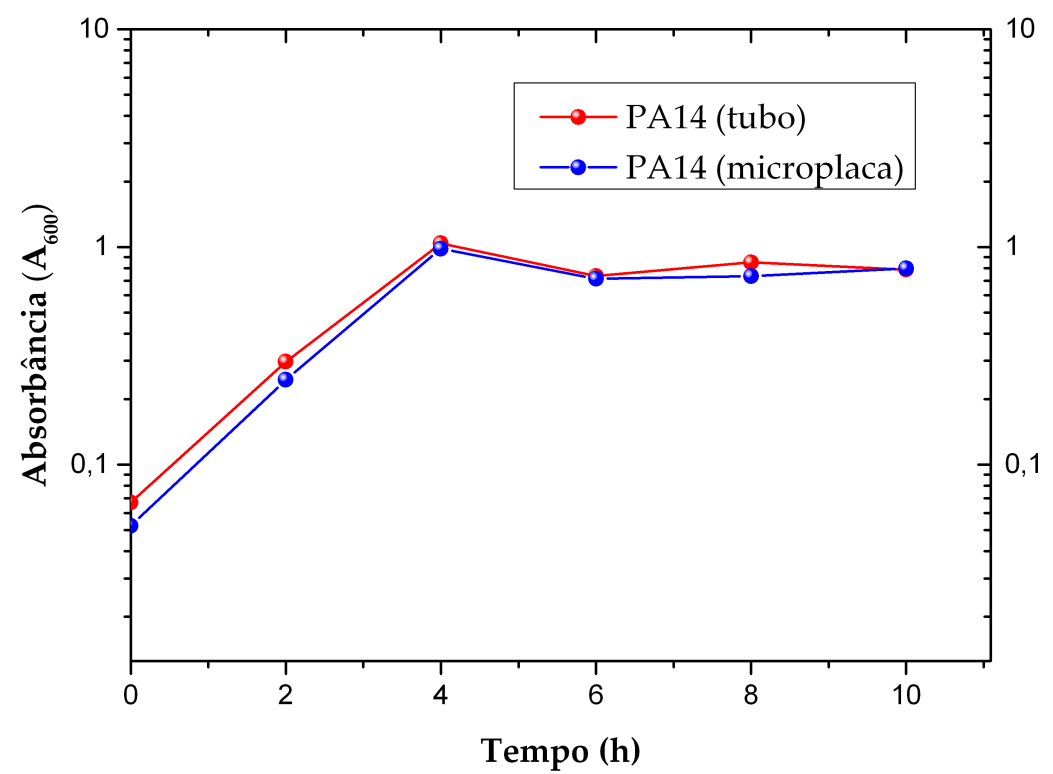

Figura 26 - Comparação do crescimento de culturas de $P$. aeruginosa PA14 crescidas em tubo de ensaio e em microplaca de $\mathbf{2 4}$ poços de 2,2 ml. As bactérias foram cultivadas em meio DPMM + Pi por 10 horas a $37^{\circ} \mathrm{C}$ sob agitação de $170 \mathrm{rpm}$. A $\mathrm{DO}_{600}$ foi determinada a cada 2 horas em um espectrofotometro de microplacas. Os dados representam o resultado de um único experimento. 